Efeito das espécies na decomposição da serapilheira e na transferência de $\mathbf{N}$ entre folhas em plantios mistos de Eucalyptus grandis e Acacia mangium

Piracicaba 




\section{LUCIANA RUGGIERO BACHEGA}

Efeito das espécies na decomposição da serapilheira e na transferência de $\mathbf{N}$ entre folhas em plantios mistos de Eucalyptus grandis e Acacia mangium

Versão revisada de acordo com a Resolução CoPGr 6018 de 2011

Dissertação apresentada ao Centro de Energia Nuclear, Universidade de São Paulo, para obtenção do título de Mestre em Ciências

Área de concentração: Energia Nuclear na Agricultura e Ambiente

Orientadora: Prof ${ }^{\mathrm{a}}$. Dr ${ }^{\mathrm{a}}$. Marisa de Cássia Piccolo

\section{Piracicaba}


AUTORIZO A DIVULGAÇÃO TOTAL OU PARCIAL DESTE TRABALHO, POR QUALQUER MEIO CONVENCIONAL OU ELETRÔNICO, PARA FINS DE ESTUDO E PESQUISA, DESDE QUE CITADA A FONTE.

Dados Internacionais de Catalogação na Publicação (CIP)

Seção Técnica de Biblioteca - CENA/USP

Bachega, Luciana Ruggiero

Efeito das espécies na decomposição da serapilheira e na transferência de $\mathrm{N}$ entre folhas em plantios mistos de Eucalyptus grandis e Acacia mangium / Luciana Ruggiero Bachega; orientadora Marisa de Cássia Piccolo. - - Versão revisada de acordo com a Resolução CoPGr 6018 de 2011. - - Piracicaba, 2012.

107 p.: il.

Dissertação (Mestrado - Programa de Pós-Graduação em Ciências. Área de Concentração: Energia Nuclear na Agricultura e Ambiente) - Centro de Energia Nuclear na Agricultura da Universidade de São Paulo.

1. Acácia 2. Ciclos biogeoquímicos 3. Consorciação de culturas 4. Eucalipto 5. Matéria orgânica do solo 6. Nitrogênio 7. Reflorestamento I. Título 


\section{AGRADECIMENTOS}

Em primeiro lugar, agradeço à Prof. ${ }^{a}$ Marisa de Cássia Piccolo pela oportunidade de trabalhar no Centro de Energia Nuclear, além do apoio, da orientação e das sugestões na realização deste trabalho;

Ao pesquisador Dr. Jean Pierre Bouillet, pela disposição e paciência em ensinar e ajudar;

Aos professores das Ciências Florestais - ESALQIUSP José Leonardo Gonçalves e Jean Paul Laclau, pelo apoio e sugestões;

Aos professores da Ecologia Isotópica - CENAIUSP Plínio de Camargo e Luiz Antonio Martinelli, pela convivência;

Aos grandes amigos do Laboratório de Ciclagem de Nutrientes, Lucas e Guilherme, por toda ajuda durante o preparo e a análise das amostras;

A todos da Estação Experimental de Ciências Florestais de Itatinga: Rildo, Elaine, Lourival, Dorival, Éder, Renan, Gerson e Welinton, e a todos que por lá passaram: Lauriane, Dionatan, George, Raniere e Eduardo;

Aos professores do CENAIUSP Paulo Trivelin e Adibe Abdalla, pelas análises e disposição em tirar minhas dúvidas durante o trabalho;

Ao professor Takashi, pelo empréstimo da balança;

À técnica do laboratório de Nutrição Mineral de Plantas, Henriquieta, pelo empréstimo do moinho e pela compreensão;

Às bibliotecárias Marília e Adriana, pela revisão deste trabalho;

Aos amigos, técnicos e estagiários da Ecologia Isotópica, por todo apoio e convivência, e aos demais amigos de Piracicaba;

Aos amigos que ficaram em São Carlos, em especial para Grace, pela sua dedicação acadêmica inspiradora;

A meus pais e irmãos, por todo incentivo e paciência desde quando o Mestrado em Piracicaba era apenas uma ideia;

À CAPES e ao CNPq, pela concessão das Bolsas de Estudo. 

"Viver no mundo sem tomar consciência do significado do mundo é como vagar por uma imensa biblioteca sem tocar os livros"

Dan Brown 



\section{RESUMO}

BACHEGA, L. R. Efeitos das espécies na decomposição da serapilheira e na transferência de $\mathrm{N}$ entre folhas em plantios mistos de Eucalyptus grandis e Acacia mangium. 2012. 107 f. Dissertação (Mestrado) - Centro de Energia Nuclear na Agricultura, Universidade de São Paulo, Piracicaba, 2012.

As espécies fixadoras de nitrogênio $(\mathrm{N})$ são utilizadas junto às plantações florestais com.

o objetivo de incremento de N. Entretanto, quando essas espécies são inseridas

à monocultura, acorre interferência na formação da serapilheira e, consequentemente, a ciclagem de nutrientes do sistema. $\mathrm{O}$ estudo foi desenvolvido em plantios puros e mistos de Eucalyptus grandis e Acacia mangium na Estação Experimental de Ciências Florestais da ESALQ - USP, em Itatinga-SP. O presente trabalho constitui-se de dois experimentos, utilizando a técnica in situ de bolsas de decomposição, e teve como objetivos: a) avaliar a dinâmica de decomposição de folhas e raízes finas de E. grandis e A. mangium em diferentes plantios, e a influência da composição química do material vegetal e do solo na ciclagem de nutrientes, a "teoria da vantagem doméstica"; b) estudar a ciclagem de nutrientes em plantios consorciados através da determinação da composição química, e a qualidade do material vegetal em decomposição; c) estimar a transferência bruta e líquida de nitrogênio durante a decomposição de folhas na mistura das duas espécies, com a finalidade de entender as interações ecológicas no consórcio do eucalipto com leguminosa. A decomposição de folhas e raízes das duas espécies estudadas apresentou perdas de massa distintas: as folhas de eucalipto (FE) decompõem-se mais rapidamente que as folhas de acácia (FA), mas não se verificaram diferenças entre raízes de acácia (RA) e raízes de eucalipto (RE). A quantidade inicial de $\mathrm{N}$ não influenciou na decomposição do material e houve imobilização deste elemento durante o período. A relação $\mathrm{C} / \mathrm{N}$ não foi eficiente como parâmetro de decomposição, pois o valor de C/N para FA foi o dobro de FE. A relação N/P apresentou uma evolução durante o experimento, tanto para folhas quanto para raízes, e pôde predizer características da comunidade microbiana, no que tange à maior prevalência de bactérias ou fungos. A lignina demonstrou-se como o componente químico responsável pelo padrão de decomposição encontrado, pois, após um ano, não se alterou sua concentração nas folhas. A transferência de $\mathrm{N}$ foi dirigida pela qualidade da folha dreno e não pela fonte; assim, FA foi o tipo de folha que recebeu mais $\mathrm{N}$ das folhas em que foram pareadas, principalmente com FE. Esses resultados demonstram que, embora o material do eucalipto seja considerado recalcitrante, após sucessivos anos de manejo desta espécie na área, a comunidade microbiana do solo foi favorável à melhor decomposição deste material que o material da acácia, mesmo em segunda rotação desta cultura.

Palavras-chave: Plantio consorciado. Decomposição. Serapilheira. Eucalipto. Acácia. 



\begin{abstract}
BACHEGA, L. R. Species effects on litter decomposition and $\mathbf{N}$ transfer between leaves in mixed plantation of Eucalyptus grandis and Acacia mangium. 2012. 107 f. Dissertação (Mestrado) - Centro de Energia Nuclear na Agricultura, Universidade de São Paulo, Piracicaba, 2012.
\end{abstract}

The nitrogen-fixing species $(\mathrm{N})$ are used with forest plantations to increase N. However when these species are inserted monoculture rushes to interference in the formation of litter, and thus the nutrient cycling of the system. The study was conducted in pure and mixed plantations of Eucalyptus grandis and Acacia mangium in the Experimental Station of Forest Sciences ESALQ-USP in Itatinga - SP. This work consists of two experiments using litterbags technique to assess the decomposition and were aimed at: a) evaluate the dynamics of decomposing leaves and fine roots of E. grandis and A. mangium plantations in different and what influence the chemical composition of plant material and soil nutrient cycling in the "home advantage theory", b) study the cycling of nutrients in plantations syndicated by determining the chemical composition and quality of material decaying plant c) estimate the gross and net transfer of nitrogen during decomposition of leaves of the mixture of the two species, in order to understand the ecological interactions in the consortium of eucalyptus and legumes. The decomposition of leaves and roots of both species showed distinct dynamics of mass loss: eucalyptus leaves (LE) decomposer faster than acacia (LA), since the roots did not differ among acacia roots (RA) and eucalyptus roots (RE). The initial amount of $\mathrm{N}$ had no influence on the decomposition of material there and immobilization element during this period. The $\mathrm{C} / \mathrm{N}$ was not effective as a parameter of decomposition, because the value of $\mathrm{C} / \mathrm{N}$ for $\mathrm{AF}$ is twice the FE. The N/P ratio had changed during the experiment, both for leaves and for roots and can predict characteristics of the microbial community, the greater prevalence of bacteria or fungi. The lignin was shown as the chemical component responsible for the pattern of decay found, because after one year did not alter its concentration in the leaves. The transfer of $\mathrm{N}$ was driven by the quality of the sheet drain and not the source, than LA was the type of leaf that received more $\mathrm{N}$ in the leaves that were paired primarily with LE. These results demonstrate that although the material is eucalyptus considered recalcitrant, after successive years of management of this species in the soil microbial community was in favor of better decomposition of this material as the material of the acacia, even in this second rotation crop.

Key-words: Mixed-plantation. Decomposition. Litter. Eucalyptus. Acacia. 



\section{LISTA DE ABREVIAÇÕES}

C: carbono

EFN: espécies fixadoras de nitrogênio

FBN: fixação biológica do nitrogênio

HFA: Home field-advantage

ID: índice de decomponibilidade

ILC: índice ligno-celulósico

$\mathrm{K}$ : potássio

MO: matéria orgânica

$\mathrm{N}$ : nitrogênio

P: fósforo

QCL: quociente holocelulose/lignocelulose

S: enxofre 



\section{LISTA DE SIGLAS}

1R: parcela com $100 \%$ de A. mangium na primeira rotação

2R: parcela com $100 \%$ de A. mangium na segunda rotação

A*A: bolsa contendo folhas de acácia marcadas com folhas de acácia não marcadas

$\mathrm{A}^{*} \mathrm{E}$ : bolsa contendo folhas de acácia marcadas com folhas de eucalipto não marcadas

AFA*: folha de acácia não marcada que esteve combinada com folha de acácia marcada

AFE*: folha de acácia não marcada que esteve combinada com folha de eucalipto marcada

$E^{*} A$ : bolsa contendo folhas de eucalipto marcadas com folhas de acácia não marcadas

$\mathrm{E}^{*} \mathrm{E}$ : bolsa contendo folhas de eucalipto marcadas com folhas de eucalipto não marcadas

E: parcela com $100 \%$ de E. grandis

EFA*: folha de eucalipto não marcada que esteve combinada com folha de acácia marcada

EFE*: folha de eucalipto não marcada que esteve combinada com folha de eucalipto marcada

FA*A: folha de acácia marcada que esteve combinada com folha de acácia não marcada

FA*E: folha de acácia marcada que esteve combinada com folha de eucalipto não marcada

FA: bolsas de decomposição contendo $100 \%$ de folhas de acácia

FA1R: tratamento folhas de acácia na parcela $100 \%$ de A. mangium na primeira rotação

FA2R: tratamento folhas de acácia na parcela $100 \%$ de A. mangium na segunda rotação

FAE: tratamento folhas de acácia na parcela $100 \%$ de E. grandis

FE*A: folha de eucalipto marcada que esteve combinada com folha de acácia não marcada

FE*E: folha de eucalipto marcada que esteve combinada com folha de eucalipto não marcada

FE: bolsas de decomposição contendo $100 \%$ de folhas de eucalipto

FE1R: tratamento folhas de eucalipto na parcela $100 \%$ de A. mangium na primeira rotação

FE2R: tratamento folhas de eucalipto na parcela $100 \%$ de A. mangium na segunda rotação

FEE: tratamento folhas de eucalipto na parcela $100 \%$ de E. grandis

RA: bolsas de decomposição contendo $100 \%$ de raízes de acácia

RA1R: tratamento raízes de acácia na parcela $100 \%$ de A. mangium na primeira rotação

RA2R: tratamento raízes de acácia na parcela $100 \%$ de A. mangium na segunda rotação

RAE: tratamento raízes de acácia na parcela $100 \%$ de E. grandis

RE: bolsas de decomposição contendo $100 \%$ de raízes de eucalipto

RE1R: tratamento raízes de eucalipto na parcela $100 \%$ de A. mangium na primeira rotação

RE2R: tratamento raízes de eucalipto na parcela $100 \%$ de A. mangium na segunda rotação

REE: tratamento raízes de eucalipto na parcela $100 \%$ de E. grandis 



\section{LISTA DE FIGURAS}

Figura 1 - Temperatura e precipitação pluviométrica médias na Estação Experimental de Itatinga no período de dez anos (2000 a 2010) .35

Figura 2 - Temperatura e precipitação pluviométrica médias na Estação Experimental de Itatinga no período estudado (outubro de 2010 a dezembro de 2011) 35

Figura 3 - Confecção das bolsas de decomposição utilizadas do Experimento A: a) bolsas de folhas nas dimensões de $20 \times 30 \mathrm{~cm}$ para acácia e $15 \times 15 \mathrm{~cm}$ para eucalipto, $10 \mathrm{~g}$ de material cada; b) bolsas de raízes nas dimensões de $15 \times 15 \mathrm{~cm}$ para acácia e eucalipto, contendo $7 \mathrm{~g}$ de material cada bolsa 37

Figura 4 - Delineamento do Experimento A para o estudo da decomposição de folhas e raízes de E. grandis e A. mangium. Três árvores por parcela foram escolhidas para a disposição das bolsas de serapilheira

Figura 5 - Disposição espacial das bolsas de serapilheira para cada parcela do Experimento "Teoria da vantagem doméstica", em outubro de 2010. As bolsas foram dispostas em três direções diferentes com uma divisória de separação entre os tipos diferentes de folhas . .40

Figura 6 - Instalação do experimento em outubro de 2010 em E. grandis puro (E), em A. mangium puro (2R ) e adicionalmente na primeira rotação de A. mangium puro (1R) .41

Figura 7 - Delineamento experimental B para estudar a transferência bruta de N entre as folhas das duas espécies, Eucalyptus e Acacia .46

Figura 8 - Instalação do experimento B nas parcelas mistas em dezembro de 2010 em a) bolsas dispostas na planta de E. grandis; b) bolsas dispostas na planta de A. mangium 47

Figura 9 - Decaimento de massa das folhas de E. grandis e A. mangium durante 367 dias de decomposição, nos tratamentos FAE, FA1R, FA2R, FEE, FE1R e FE2R. Os valores representam a média $(n=9) \pm$ desvio padrão .51

Figura 10 - Decaimento de massa das raízes de E. grandis e A. mangium durante 367 dias de decomposição, nos tratamentos RAE, RA1R, RA2R, REE, RE1R e RE2R. Os valores representam a média $(n=9) \pm$ desvio padrão . .51

Figura 11 - Teores de lignina, celulose, hemicelulose e carboidratos solúveis nas folhas (a) e raízes (b) de Eucalyptus grandis e Acacia mangium durante o experimento de decomposição: a) folhas nos tratamentos FAE, FA1R, FA2R, FEE, FE1R e FE2R; 
b) raízes nos tratamentos RAE, RA1R, RA2R, REE, RE1R e RE2R. Os valores representam a média $(n=9) \pm$ desvio padrão

Figura 12 - Teores de taninos totais, taninos condensados e outros fenóis nas folhas (a) e raízes (b) de Eucalyptus grandis e Acacia mangium durante o experimento de decomposição: a) folhas nos tratamentos FAE, FA1R, FA2R, FEE, FE1R e FE2R; b) raízes nos tratamentos RAE, RA1R, RA2R, REE, RE1R e RE2R. Os valores representam a média $(n=9) \pm$ desvio padrão 56

Figura 13 - Teores (a) e quantidades (b) de carbono nas folhas de E. grandis e A. mangium durante o experimento de decomposição nos tratamentos FAE, FA1R, FA2R, FEE, FE1R e FE2R. Os valores representam a média $(n=9) \pm$ desvio padrão .......58

Figura 14 - Teores (a) e quantidades (b) de carbono nas raízes de E. grandis e A. mangium durante o experimento de decomposição nos tratamentos RAE, RA1R, RA2R, REE, RE1R e RE2R. Os valores representam a média (n=9) \pm desvio padrão ....59

Figura 15 - Teores (a) e quantidades (b) de nitrogênio nas folhas de E. grandis e A. mangium durante o experimento de decomposição nos FAE, FA1R, FA2R, FEE, FE1R e FE2R. Os valores representam a média $(n=9) \pm$ desvio padrão .61

Figura 16 - Teores (a) e quantidades (b) de nitrogênio nas raízes de E. grandis e A. mangium durante o experimento de decomposição nos tratamentos RAE, RA1R, RA2R, REE, RE1R e RE2R. Os valores representam a média $(n=9) \pm$ desvio padrão ....63

Figura 17 - Teores (a) e quantidades (b) de enxofre nas folhas de E. grandis e A. mangium durante o experimento de decomposição nos FAE, FA1R, FA2R, FEE, FE1R e FE2R. Os valores representam a média $(n=9) \pm$ desvio padrão .64

Figura 18 - Teores (a) e quantidades (b) de enxofre nas raízes de E. grandis e A. mangium durante o experimento de decomposição nos tratamentos RAE, RA1R, RA2R, REE, RE1R e RE2R. Os valores representam a média (n=9) \pm desvio padrão ....65

Figura 19 - Teores (a) e quantidades (b) de fósforo nas folhas de E. grandis e A. mangium durante o experimento de decomposição nos tratamentos FAE, FA1R, FA2R, FEE, FE1R e FE2R. Os valores representam a média $(n=9) \pm$ desvio padrão ......66

Figura 20 - Teores (a) e quantidades (b) de fósforo nas raízes de E. grandis e A. mangium durante o experimento de decomposição nos tratamentos RAE, RA1R, RA2R, REE, RE1R e RE2R. Os valores representam a média $(n=9) \pm$ desvio padrão ....67

Figura 21- Teores (a) e quantidades (b) de potássio nas folhas de E. grandis e A. mangium durante o experimento de decomposição nos tratamentos FAE, FA1R, FA2R, FEE, FE1R e FE2R. Os valores representam a média $(n=9) \pm$ desvio padrão. 
Figura 22 - Teores (a) e quantidades (b) de potássio nas raízes de E. grandis e A. mangium durante o experimento de decomposição nos tratamentos RAE, RA1R, RA2R, REE, RE1R e RE2R. Os valores representam a média $(n=9) \pm$ desvio padrão ....70

Figura 23 - Relação C/N nas folhas (a) e raízes (b) de Eucalyptus grandis e Acacia mangium durante o experimento de decomposição: a) folhas nos tratamentos FAE, FA1R, FA2R, FEE, FE1R e FE2R; b) raízes nos tratamentos RAE, RA1R, RA2R, REE, RE1R e RE2R. Os valores representam a média $(n=9) \pm$ desvio padrão .73

Figura 24 - Relação N/P nas folhas (a) e raízes (b) de E. grandis e A. mangium durante o experimento de decomposição: a) folhas nos tratamentos FAE, FA1R, FA2R, FEE, FE1R e FE2R; b) raízes nos tratamentos RAE, RA1R, RA2R, REE, RE1R e RE2R. Os valores representam a média $(n=9) \pm$ desvio padrão .74

Figura 25 - Fluxos de quantidade (g) de nitrogênio total durante o experimento de transferência de $\mathrm{N}$ entre os tratamentos drenos AFA*, AFE*, EFA* e EFE*. Os valores representam a média $(n=3-4) \pm$ desvio padrão . .78

Figura 26 - Transferência de $\mathrm{N}$ entre as folhas nos tratamentos de drenos AFA*, AFE*, EFA* e EFE*. Os valores representam a média $(n=3-4) \pm$ desvio padrão .80 



\section{SUMÁRIO}

1 INTRODUÇÃo .017

2 REVISÃO DA LITERATURA.......................................................................................20

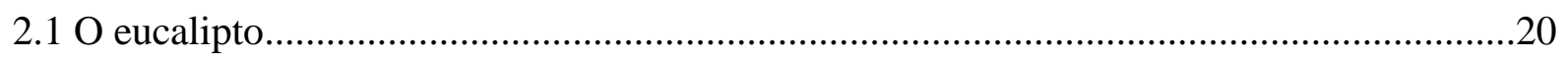

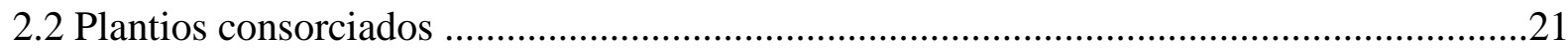

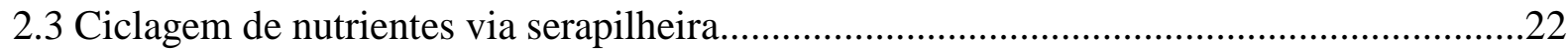

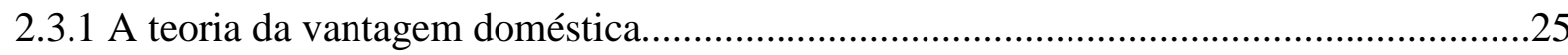

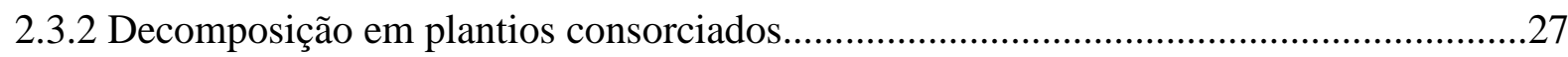

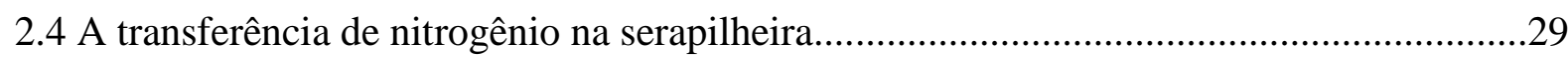

2.4.1 O uso da técnica isotópica na transferência de nitrogênio............................................31

3 MATERIAL E MÉTODOS.......................................................................................34

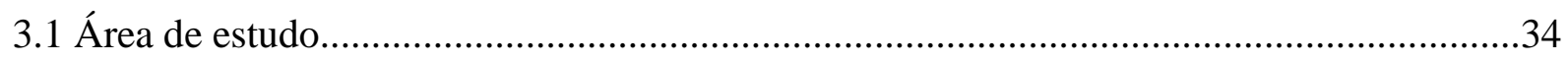

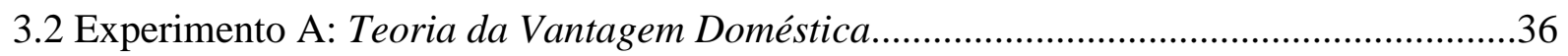

3.2.1 Preparo das bolsas de decomposição de serapilheira e raízes..........................................36

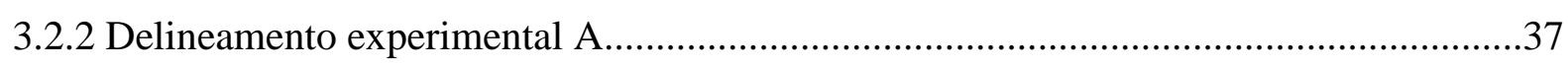

3.2.3 Instalação e coleta das bolsas de decomposição............................................................ 41

3.2.4 Preparo e análises das amostras de serapilheira e raízes.................................................41

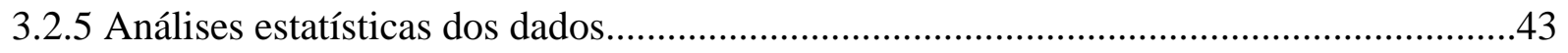

3.3 Experimento B: Transferência Bruta de N na Serapilheira...............................................44

3.3.1 Preparo das bolsas de decomposição para transferência..................................................44

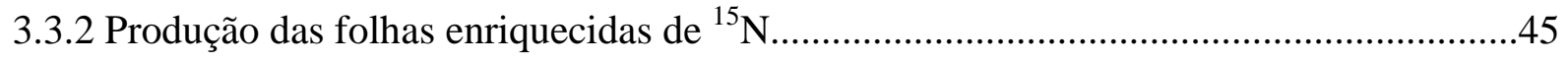

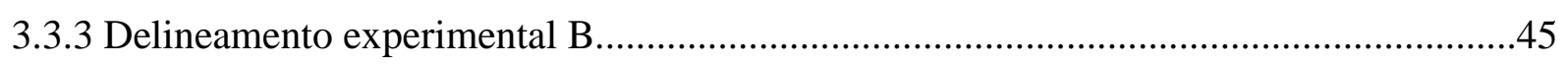

3.3.4 Instalação do experimento e coleta das bolsas de decomposição....................................46

3.3.5 Análises de $\mathrm{N}$-total e átomos $\%$ de ${ }^{15} \mathrm{~N}$ das folhas em transferência...............................48

3.3.6 Determinação da transferência bruta de $\mathrm{N}$ entre as folhas..............................................48

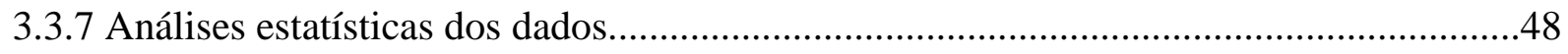

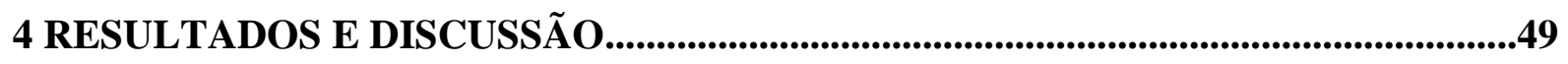

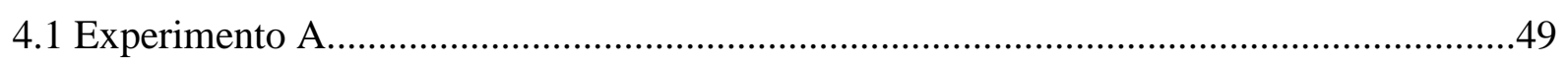

4.1.1 Perda de massa de folhas e raízes durante a decomposição...........................................49

4.1.2 Composição de compostos orgânicos das folhas e raízes em decomposição...................52 
4.1.3 Dinâmica de carbono, nitrogênio, enxofre, fósforo e potássio em folhas e raízes...........57

4.1.4 Índices de decomposição das folhas e raízes...............................................................70

4.1.5 Índices de qualidade de decomposição para folhas e raízes...........................................75

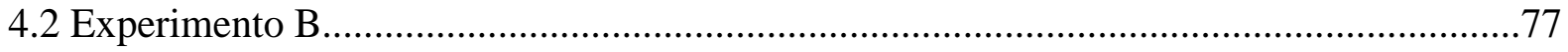

4.2.1 N-total nas folhas durante a transferência de N...........................................................77

4.2.2 Taxa de transferência de $\mathrm{N}$ entre as folhas durante a decomposição..............................78

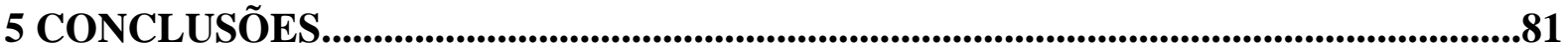

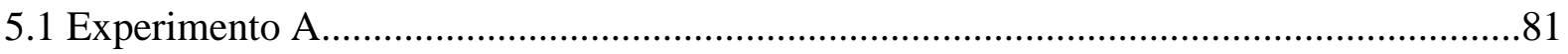

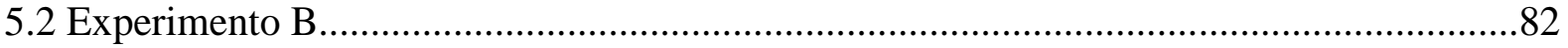

6 CONSIDERAÇÕES FINAIS DOS EXPERIMENTOS...................................................83

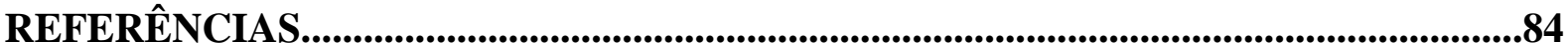

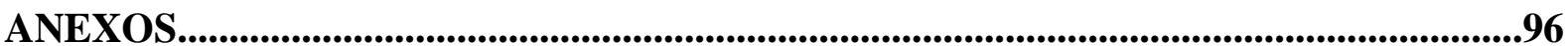





\section{INTRODUÇÃO}

A madeira é um recurso natural bastante utilizado e tem como principais derivados os seguimentos de papel e celulose, carvão vegetal, painéis de madeira, compensados, madeira serrada, entre outros, o que coloca os produtos de origem florestal entre os dez mais comercializados no mundo. A Organização das Nações Unidas para Agricultura e Alimentação (FAO) estima para os próximos 20 anos um aumento de 50\% de produção mundial de madeira (SBS, 2008). O Brasil atingiu em 2010 o montante de 7,5 bilhões de dólares em exportações de derivados florestais, sendo a celulose responsável por $60 \%$ deste valor (ABRAF, 2011).

O uso de florestas plantadas de rápido crescimento e produtividade, como Eucalyptus e Pinus, satisfaz a demanda por madeira e, ao mesmo tempo, diminui a pressão pelas florestas. O Eucalipto possui ampla diversidade de espécies, grande capacidade de adaptação e aplicação diversa de seu produto (MORA; GARCIA, 2000). Em 2007, havia no mundo 25 milhões de hectares plantados com eucalipto, o que reflete na economia de muitos países (SILVA, 2009).

O Brasil, a partir da década de 1990, se consolidou entre os países mais representativos no setor de produção de madeira, alcançando o primeiro lugar na exportação de celulose de fibra de eucalipto, apesar de as áreas destinadas à silvicultura somarem apenas 0,7\% do território nacional (SBS, 2008). No Brasil, em 2010, uma área de 6,5 milhões de hectares estava ocupada por Eucalipto e Pinus, sendo $70 \%$ da área total com Eucalipto (ABRAF, 2011). A Associação Brasileira de Celulose e Papel prevê um crescimento no setor, para 2020 , de $57 \%$ em celulose e $30 \%$ em papel.

As áreas de silvicultura estão localizadas em solos de baixa fertilidade no Brasil e em outras regiões subtropicais e tropicais do mundo. O sistema radicular muito desenvolvido do eucalipto possibilita a exploração de camadas profundas do solo com eficiente absorção de nutrientes (CHRISTINA et al., 2011). Embora consiga boa resposta de crescimento nestas condições, assim como outras culturas florestais de curta rotação, é grande a sua demanda de nutrientes, que são armazenados em diferentes compartimentos das árvores e posteriormente exportados durante o corte. Esta situação levou à aplicação de grandes quantidades de fertilizantes na última década (GONÇALVES et al., 2004) e significou um grande custo econômico à silvicultura no Brasil, além de uma potencial fonte de interferência no solo. O nitrogênio $(\mathrm{N})$ no solo, após ação de microrganismos nitrificantes, é convertido a nitrato, um composto altamente solúvel, com capacidade de migrar no perfil 
do solo e causar a contaminação do lençol freático. Entretanto, devido à profunda drenagem, o eucalipto mostrou-se eficiente em limitar as perdas de nutrientes em solos arenosos no Brasil (LACLAU et al., 2010).

Uma forma de suprimento de $\mathrm{N}$ com estratégia na sustentabilidade, no aumento da produção e também na disponibilidade de $\mathrm{N}$ no solo é o uso da fixação biológica do nitrogênio (FBN) no sistema de produção. A introdução de espécies fixadoras de $\mathrm{N}$ faz-se em rotação de culturas, cultivo consorciado, adubação verde e recuperação de áreas degradadas (LOPES, 2007). O objetivo do consorciado de espécies fixadoras de nitrogênio em plantações florestais pode não ser apenas a adição de $\mathrm{N}$ no sistema, mas também o aumento do volume de biomossa, biodiversidade e qualidade da madeira (FORRESTER et al., 2006). O incremento da biodiversidade por interações interespecíficas entre os organismos é um valor importante para a qualidade ambiental, levantado pela Agenda 21 para a silvicultura. Além disso, o interesse das empresas do setor florestal em plantios consorciados visa a certificações e difusão das atividades ambientais para o mercado consumidor.

Os trabalhos sobre plantio consorciado de leguminosas arbóreas com eucalipto no Brasil são recentes, com demanda para realização de mais pesquisas nesta área (MACEDO; VALE; VENTURIN, 2010). Os resultados monstraram-se controversos, pois há diferentes graus de relações interespecíficas, que ocasionam limitação no crescimento do eucalipto comparado ao plantio puro (COELHO et al., 2007) ou o aumento do volume e da altura em ambas as espécies (BAUHU; KHANNA; MENDEN, 2000). Outros resultados também apontam que o plantio consorciado favorece a nutrição do eucalipto e incrementa o estoque de $\mathrm{N}$ no ecossistema, enquanto mantém inalterada a produção total de madeira (VEZZANI; TEDESCO; BARROS, 2001, VIERA; SCHUMACHER; LIBERALESSO, 2011).

A presença de espécies fixadoras de nitrogênio (EFN) pode alterar a decomposição em um consórcio com eucalipto. A adição de um material de melhor qualidade (maior concentração de $\mathrm{N}$ ) e que normalmente apresenta rápida decomposição tem efeitos durante a decomposição do consórcio. Entretanto, a composição química do material não controla apenas a velocidade de decomposição, mas também a atividade microbiana do solo. Assim, espécies individuais podem modificar a interação solo-planta com o incremento no decaimento da serapilheira, de maneira a criar-se seu próprio ambiente. Esta é a "teoria da vantagem doméstica" ou "Home field-advantage" (HFA) (GHOLZ et al., 2000; CHAPMAN; KOCH, 2007). 
O presente trabalho teve como objetivos:

- Avaliar a decomposição de folhas e raízes finas de Eucalyptus grandis e Acacia mangium em diferentes plantios e verificar qual a influência da composição química do material vegetal e do solo na ciclagem de nutrientes, a "teoria da vantagem doméstica" (Home fieldadvantage);

- Estudar a ciclagem de nutrientes em plantios consorciados através da determinação da composição química (carbono e macronutrientes) e bioquímica (celulose, hemicelulose, lignina, taninos totais e condensados, fenóis solúveis e carboidratos solúveis) do material vegetal em decomposição;

- Estimar a transferência bruta e líquida de nitrogênio durante a decomposição de folhas da mistura das duas espécies, com a finalidade de entender as interações ecológicas que podem ocorrer no consórcio do eucalipto com leguminosa. 


\section{REVISÃO DA LITERATURA}

\subsection{O eucalipto}

Os produtos derivados das florestas plantadas possuem muitas utilidades ao abastecer as indústrias, fornecer carvão e lenha na produção de energia e reduzir o uso de florestas nativas. As florestas plantadas são uma opção efetiva de captura de carbono (C), com a capacidade de imobilizar $50 \mathrm{t} \mathrm{ha}^{-1}$ ano $^{-1}$ de $\mathrm{CO}_{2}$ da atmosfera (GATTO et al., 2010). Antes do século $\mathrm{XX}$, as florestas nativas supriam a demanda por produtos florestais, não havendo necessidade de plantar árvores para o abastecimento industrial da madeira. Os primeiros plantios florestais ocorreram na Europa, com o gênero florestal mais representativo, o eucalipto (LEÃO, 2000). A origem do eucalipto é no continente australiano, com mais de 600 espécies, sendo a maioria delas de altura entre 30 e 50 metros, outras entre 10 e 25 , e algumas até arbustivas (MORA; GARCIA, 2000). Na segunda metade do século XIX, o eucalipto passou a ser utilizado em outros locais, tais como Espanha, África do Sul e América do Sul.

A escolha entre as diversas espécies de eucalipto existentes é de acordo com as condições do local de plantio e as semelhanças com as do local de origem. A espécie Eucalyptus grandis é de clima temperado quente a subtropical moderado com invernos suaves, sendo a mais utilizada no Brasil (MORA; GARCIA, 2000), devido à forte produtividade, a boa forma do tronco e a qualidade das fibras produzidas.

O plantio do eucalipto no Brasil teve início em 1904, para a produção de lenha e dormentes no Estado de São Paulo (MORA; GARCIA, 2000). O gênero florestal apresentou condições ideais de crescimento que, somadas aos programas de melhoramentos, tornaram a produtividade brasileira superior à de outros países, como Portugal, Espanha e África do Sul. Até o ano de 2009, o Brasil possuía 6,31 milhões de hectares de área destinada a plantações florestais, sendo 4,51 milhões de hectares plantados com eucalipto (ABRAF, 2010). O Serviço Florestal Brasileiro (2010) estima que até 2020 o total de área de florestas plantadas será entre 11 e 14 milhões de hectares.

A partir da expansão das monoculturas florestais, surgiram críticas sobre seus efeitos ambientais no solo, na água e na biodiversidade. Um dos efeitos no solo é a exportação de nutrientes durante a colheita florestal de até $60 \%$ da biomassa produzida (aproximadamente $200 \mathrm{Mg} \mathrm{ha}^{-1}$ ), o que afeta a ciclagem de nutrientes do sistema 
(HERNÁNDEZ et al., 2009). Apesar de ser considerada uma relação pequena em comparação a culturas agrícolas, há uma demanda de fertilização cuja resposta é maior em solos com menor teor de matéria orgânica (MO) (LACLAU et al., 2005). Gonçalves et al. (1996) propõem uma classe de adubação com base no teor de MO do solo, sendo 60, 40 e $20 \mathrm{~kg} \mathrm{ha}{ }^{-1}$ de $\mathrm{N}$ para 0-20, 21-50 e >50 $\mathrm{g} \mathrm{kg}^{-1}$ de $\mathrm{MO}$, respectivamente.

\subsection{Plantios consorciados}

Existem diversas leguminosas arbóreas nativas no Brasil, tais como Peltophorum dubium, Mimosa scabrella e Mimosa caesalpiniaefolia, entre outras. Entretanto, a espécie exótica Acacia mangium é a que pode se apresentar como uma espécie de competitivo crescimento quando consorciada junto ao eucalipto (COELHO et al., 2007). As acácias são leguminosas do subfilo Mimosaceae e possuem madeira indicada para lenha, carvão, celulose, papel e painéis de madeira. Também possuem taninos usados para curtumes e borrachas, o que constitui alternativas promissoras para a agricultura e para a silvicultura (FOELKEL, 2008). Essas espécies de leguminosas são muito cultivadas na Indonésia e o Brasil totalizou, em 2010, uma área plantada de 127 ha de acácias, principalmente nos Estados do Rio Grande do Sul e de Roraima (ABRAF, 2011). Além do retorno econômico, o reflorestamento de Acacia mangium permite recuperar as camadas do solo em função do aumento dos estoques de MO (GARAY et al., 2003), além de e também beneficiar o sequestro de C no solo (KUNHAMU; KUMAR; VISWANATH, 2009).

A adição de EFN aos monocultivos contribui potencialmente para a sustentabilidade da plantação florestal e para o aumento da produção de madeira pelo incremento de N. Porém, a quantidade de FBN varia entre valores menores que um e maiores que $200 \mathrm{~kg} \mathrm{~N}^{-1}$ ano $^{-1}$ (FORRESTER et al., 2006), dependendo das condições de crescimento e competição. Bouillet et al. (2008) encontraram que o valor de $\mathrm{N}$ acumulado em espécies fixadoras, quando consorciadas com eucalipto, foi menor do que nos plantios puros (BOUILLET et al., 2008).

Os efeitos das EFNs em plantio consorciado podem ocorrer de diversas maneiras: (1) pela adição de $\mathrm{N}$ através da fixação de $\mathrm{N}$ atmosférico, minimizando a aplicação de fertilizantes nitrogenados e aumentando os estoques de N na MO; (2) por alterações nas taxas de mineralização, nitrificação, desnitrificação, alteração na produção e decomposição da serapilheira, e na decomposição das raízes; (3) pelos efeitos positivos sobre outros nutrientes, como a adição de fósforo (P) pelas espécies fixadoras, e (4) pela alteração devida 
a outros fatores indiretos, como a precipitação e a interceptação das chuvas, e a atividade da macro e da microfauna (KHANNA, 1998).

Além da FBN, a mistura de leguminosas e eucalipto apresenta competições entre as espécies em diversos graus: intra e interespecífica. Coelho et al. (2007) observaram no plantio misto de eucalipto com diversas espécies fixadoras de $\mathrm{N}$ que a competição interespecífica foi maior que a intraespecífica, pois, quando consorciado, o eucalipto teve a menor produção de biomassa. Laclau et al. (2008) também encontraram competição interespecífica em plantio consorciado de E. grandis e A. mangium. A concorrência por luz no início dos estágios de crescimento entre as espécies induziu a um dossel estratificado, com preferência de alocação de biomassa da acácia para o crescimento vertical e menos para a área basal e o desenvolvimento de raízes (LACLAU et al., 2010).

\subsection{Ciclagem de nutrientes via serapilheira}

A queda de resíduos senescentes da parte aérea das plantas no solo forma o conjunto serapilheira-solo e é nesta faixa onde ocorrem as interações entre o solo e a vegetação (MOREIRA; SIQUEIRA, 2006). A serapilheira pode ser definida como o material decíduo na superfície do solo da floresta e é constituída por folhas, caules, ramos, frutos, flores e outras partes da planta, além de restos de animais e material fecal. A quantidade e a qualidade da serapilheira são variáveis, pois dependem de fatores, como a composição da comunidade vegetal, o clima, o solo, as características genéticas das plantas, a idade e a densidade de plantas (CORREIA; ANDRADE, 2008).

Diversos fatores, tanto bióticos quanto abióticos, influenciam no acúmulo de material vegetal na camada acima do solo, tais como: tipo da vegetação, precipitação, temperatura, luminosidade, relevo, deciduidade, estádio sucessional, disponibilidade hídrica e características do solo. Dependendo do ecossistema, um determinado fator pode prevalecer sobre os demais. Calvi, Pereira e Junior (2009) verificaram, em florestas tropicais no Estado do Espírito Santo, o aumento na deposição da serapilheira no período de clima úmido e a redução do material decíduo no período seco. Em estudo de Martins (2010), a produção de serapilheira decresceu com o gradiente altitudinal da Floresta Ombrófila Densa. Quanto maior o tamanho da copa das árvores, maior é a produção de serapilheira (CALVI; PEREIRA; JUNIOR, 2009). A qualidade da serapilheira, isto é, sua composição química, pode ser 
significativamente diferente entre espécies, mesmo em condições homogêneas de crescimento (VIVANCO; AUSTIN, 2006).

Além dos fatores de produção, o estoque de serapilheira também é controlado pela taxa de decomposição, definida como a transformação do material orgânico em partículas e polímeros, que são utilizados pelos microrganismos (MOREIRA; SIQUEIRA, 2006). Esses organismos, os decompositores, assimilam parte dos compostos ligados ao $\mathrm{C}$, como o N, e parte é mineralizada e disponível aos vegetais.

A degradação da serapilheira inicia-se antes mesmo da folha atingir o solo, por causa da ação de macro e microrganismos na árvore. Há, na superfície das folhas, bactérias e fungos responsáveis pela ciclagem de nutrientes, que contribuem para a decomposição de compostos orgânicos (LEVEAU, 2009). Entretanto, é no conjunto serapilheira-solo que está a biota responsável pelas principais reações de decomposição da $\mathrm{MO}$ e de ciclagem de nutrientes (CORREIA; ANDRADE, 2008).

A velocidade de decomposição da serapilheira e de seus compostos orgânicos depende da sua composição estrutural (VIVANCO; AUSTIN, 2006) somada às condições ambientais presentes (CORREIA; ANDRADE, 2008). As condições ambientais se referem ao clima em que o ecossistema está inserido ou ao microclima que este condiciona. Desta maneira, em uma floresta, a retirada do sub-bosque de uma floresta que protege a serapilheira da perda de água e da exposição direta ao sol pode aumentar a taxa de decomposição das espécies no local (XIONG et al., 2008). As mudanças no uso da terra também interferem na decomposição e as maiores taxas foram encontradas para culturas agrícolas, quando comparadas com as de florestas naturais (BAKKER; CARREÑO-ROCABADO; POORTER, 2011).

A composição química do material vegetal é utilizada como um dos parâmetros em estudos de decomposição da serapilheira (VIVANCO; AUSTIN, 2006). Entre os parâmetros químicos, a relação $\mathrm{C} / \mathrm{N}$ é um dos principais indicadores da velocidade de decomposição (MOORHEAD et al., 1999). Elevadas relações C/N ocasionam a imobilização do $\mathrm{N}$ mineral, que pode ser uma situação temporária, na qual os próprios organismos responsáveis pela decomposição param a nitrificação por falta de substrato. Assim, quando a relação $\mathrm{C} / \mathrm{N}$ apresenta valores entre 20 e 30, há um equilíbrio entre os processos de mineralização e de imobilização de $\mathrm{N}$, e quando o valor é superior a 30, a imobilização é superior à mineralização (SIQUEIRA; FRANCO, 1988).

A qualidade dos compostos carbônicos muitas vezes tem maior influência nas taxas de decomposição do que o teor bruto de $\mathrm{C}$ e $\mathrm{N}$, e dos demais nutrientes. Os teores 
de C solúvel, celulose, lignina e a relação lignina/N no material vegetal são indicadores mais específicos para o decaimento do material vegetal (BERG, 1984; AITA; GIACOMINI, 2007). Estes componentes do material não têm a mesma ação na decomposição: os compostos de $\mathrm{C}$ solúveis reagem positivamente à decomposição e à perda de massa; diversamente, a celulose e a lignina ocasionam o efeito oposto (VIVANCO; AUSTIN, 2008). A lignina é o biopolímero vegetal mais abundante, com alto peso molecular e apresenta complexa estrutura tridimensional com unidades aromáticas e capacidade de formar complexos com os argilominerais no solo. Essas características da lignina lhe conferem características recalcitrantes e uma extensa rota de degradação (MOREIRA; SIQUEIRA, 2006).

O fósforo é um elemento que influencia na decomposição do material vegetal por ser um elemento fundamental na síntese celular dos microrganismos decompositores. Sua concentração é muitas vezes relacionada à de $\mathrm{N}$, pois a comunidade microbiana decompositora requer proporções equilibradas entre N e P (BERG; MATZNER, 1997). Em elevada concentração de $\mathrm{N}$ disponível, pode haver uma relativa falta de $\mathrm{P}$ durante a decomposição, sendo este o elemento limitante (KUPERMAN, 1999). A disponibilidade de P inplicará no predomínio de microrganismo: bactérias ou fungos. As bactérias são mais exigentes em relação ao $\mathrm{P}$, prevalescendo em baixa relação N/P, e os fungos predominam em meio P limitante (alta N/P) (WARDLE; WALKER; BARDGETT, 2004). Portanto, o N é o elemento limitante quando a relação N/P é baixa $(\mathrm{N} / \mathrm{P}=5$ a 10$)$ e o P é o limitante quando a relação é alta (N/P= 80 a 160) (GÜSEWELL; GESSNER, 2009).

O elemento potássio $(\mathrm{K})$ não possui relação direta com a taxa de decomposição, pois não é um fator limitante ao crescimento e à atividade dos microrganismos. $\mathrm{O} \mathrm{K}$ é o elemento que apresenta grande perda inicial durante a decomposição de material vegetal, de até $80 \%$ nos primeiros quatro meses (HERNÁNDEZ et al., 2009). Essa perda representa a lixiviação de $\mathrm{K}$ durante a decomposição, pois nas células vegetais este elemento está em formas livres $\left(\mathrm{K}^{+}\right)$e não constitui compostos orgânicos (O’CONNEL; GROVE, 1996).

Os vegetais relacionam sua composição química estrutural com suas estratégias de desenvolvimento ecológico. Ao mesmo tempo em que as folhas são resistentes aos predadores em virtude de elevada densidade, quantidade de matéria seca e tenacidade -, também são resistentes aos decompositores. A decomposição ainda varia de acordo com o estágio de sucessão, na medida em que plantas de crescimento lento, folhas de sombra e bem protegidas decompõem-se mais lentamente do que as de crescimento rápido e com exigência de luz (BAKKER; CARREÑO-ROCABADO; POORTER, 2011). 
A decomposição do material vegetal presente abaixo do solo, como as raízes, também contribui para a formação da MO do solo. Em plantios mistos de A. Mangium e E. Grandis, a porcentagem de $\mathrm{N}$ acumulada na biomassa das raízes atinge $20 \%$, indicando que a dinâmica da ciclagem de nutrientes abaixo do solo é fundamental para estimar a ciclagem de $\mathrm{N}$ do sistema, incluindo plantios mistos com leguminosas (BOUILLET et al., 2008).

Abaixo do solo, podem ocorrer diversas limitações para o desenvolvimento e a atividade das comunidades microbianas decompositoras. Em diferentes profundidades, há variação na temperatura, na disponibilidade de oxigênio e água, nos agregados do solo e na quantidade de MO (SANAULLAH et al., 2011). Embora incrementem a MO do solo, a presença de raízes pode influenciar de modo negativo na decomposição em razão da competição por nutrientes entre o vegetal e os microrganismos do solo (COQ et al., 2011).

Desta maneira, a decomposição do material é um processo complexo, que envolve o ambiente físico-químico, a qualidade do substrato e a comunidade de organismos decompositores. A ciclagem dos nutrientes no manejo do eucalipto tem grande potencial de retorno de nutrientes ao solo, pois as folhas apresentam as maiores concentrações de $\mathrm{N}$, P e K entre os resíduos de uma colheita florestal (HERNÁNDEZ et al., 2009).

\subsubsection{A teoria da vantagem doméstica}

A composição química do material vegetal não controla apenas a velocidade da decomposição, mas também a atividade microbiana do solo, incluindo seus decompositores. Espécies de plantas individuais podem alterar a interação solo-planta, proporcionando incremento na decomposição da MO da espécie; desta maneira, cria-se seu próprio microambiente (VIVANCO; AUSTIN, 2008). O acréscimo na decomposição acarreta no aumento de nutrientes disponíveis à planta, o que permite o aumento da sua competitividade dentro da comunidade vegetal. Esta é a "teoria da vantagem doméstica" ou HFA (GHOLZ et al., 2000; CHAPMAN; KOCH, 2007). Assim, em uma floresta onde não há diferença na fertilidade do solo, espécies de vegetais decompõem melhor sua serapilheira que as de origens diferentes (VIVANCO; AUSTIN, 2008).

A teorida da vantagem doméstica está relacionada com o tempo de decomposição e pode não acontecer na fase inicial (AYRES; DROMPH; BARDGETT, 2006). O tempo para a ocorrência da HFA depende de fatores biológicos, como (1) a capacidade de colonização dos microrganismos decompositores; (2) os parâmetros químicos do material vegetal 
relacionados à decomposição, e (3) a mudança na composição do material ao longo do processo, que pode prejudicar os decompositores presentes (AYRES et al., 2009).

Quando o material vegetal de diferentes espécies decompõe-se concomitantemente, no mesmo espaço, pode haver mudanças na decomposição desta mistura serapilheira, por meio de efeitos aditivos e não-aditivos (COQ et al., 2011). Em caso de efeitos aditivos, a decomposição da mistura é equivalente à soma da decomposição das partes separadas. O efeito também pode ser nulo pela forte interação entre planta e solo, e a decomposição da mistura ocorre da mesma maneira de quando as espécies vegetais estão sozinhas (VIVANCO; AUSTIN, 2008).

Os resultados positivos na decomposição são efeitos de sinergia com a diversidade de espécies e a diversidade química. A diferença nutricional no plantio consorciado tem a capacidade de aumentar a produtividade, a utilização de nutrientes, a resistência e a resiliência às perturbações no meio. Entretanto, os efeitos sinérgicos não são alcançados em todas as combinações: em relação à taxonomia, nas espécies de plantas mais relacionadas, há aumento na taxa de decomposição na mistura da serapilheira, o que não ocorre quando há combinação de espécies mais distintas (CHAMPMAN; KOCH, 2007). Efeitos sinérgicos na perda de massa ocorrem também mais facilmente em combinações de serapilheira entre grupos funcionais (MAISTO et al., 2011).

Em plantios consorciados entre E. grandis e A. mangium, as folhas de acácia tiveram os maiores teores de N (BOUILLET et al., 2008). Desta maneira, a adição de folhas de EFN junto às folhas de eucalipto tem a capacidade de aumentar a quantidade de $\mathrm{N}$ disponível aos microrganismos, o que permite acelerar os estágios de decomposição (XIANG; BAUHUS, 2007).

Altas taxas de perda de massa durante a decomposição podem não ser derivadas de propriedades sinérgicas entre solo e material vegetal. Solos férteis e com serapilheira de alta qualidade química apresentam altas taxas de decomposição, as quais se devem às altas quantidades de nutrientes disponíveis aos microrganismos. Vivando e Austin (2008) afirmam que o real efeito sinérgico ocorre quando um material vegetal de baixa qualidade química decompõe-se melhor em seu próprio ambiente. Na decomposição de uma mistura entre folhas de alta qualidade química e folhas com baixa qualidade, não foram observadas interações, pois a decomposição das folhas de menor qualidade não apresentou mudanças com a adição das outras folhas (SCHWENDENER et al., 2005). 
Em locais onde o $\mathrm{N}$ não é limitante, por exemplo, com fertilização nitrogenada, os efeitos aditivos na decomposição transformam-se em efeitos não aditivos. A fertilização também elimina a relação entre o material vegetal e seus decompositores, pois a adição de $\mathrm{N}$ pode influenciar positivamente a enzima lignina-degradante, estimulando a decomposição de compostos mais recalcitrantes (VIVANCO; AUSTIN, 2011).

Efeitos negativos podem surgir quando espécies de composição química diferentes são misturadas e quando a composição destas espécies é rica em compostos secundários de difícil decomposição (COQ et al., 2011). Esses autores afirmam que a composição química de algumas espécies, como a de compostos tóxicos e taninos, pode inibir o crescimento microbiano.

\subsubsection{Decomposição em plantios consorciados}

$\mathrm{Na}$ substituição da cobertura nativa por florestas plantadas de Eucalyptus, há alterações na qualidade do material vegetal sobre o solo em relação à sua heterogeneidade, o que pode influenciar negativamente na decomposição da serapilheira. Louzada, Schoereder e De Marco (1997) observaram que, no plantio de eucalipto, a serapilheira da floresta nativa decompôs-se mais rapidamente do que da espécie invasora. A serapilheira de alta qualidade da floresta permitiu a atividade da fauna local, aumentando a velocidade da decomposição dos resíduos (LOUZADA; SCHOEREDER; DE MARCO, 1997). As EFNs normalmente são espécies de rápida decomposição por apresentaram um material vegetal de melhor qualidade (maior concentração de N). Entretanto, a decomposição de Acacia mangium demonstrou-se lenta, tendo Balieiro et al. (2003) observado, no plantio puro da espécie de leguminosa, grande quantidade de serapilheira acumulada sobre o solo após cinco anos.

No plantio consorciado entre eucalipto e leguminosa, a decomposição da serapilheira pode ser alterada desde o início, pois a quantidade produzida é diferente da apresentada pelas monoculturas. Em três anos, o plantio de A. mangium em monocultura teve acumulo de 8,8 $\mathrm{Mg} \mathrm{ha}^{-1}$ de serapilheira' enquanto que, em plantio misto com eucalipto, o valor diminui para $1,1 \mathrm{Mg} \mathrm{ha}^{-1}$. No mesmo período, nas monoculturas de E. grandis, a quantidade produzida é de 13,5 $\mathrm{Mg} \mathrm{ha}^{-1}$ e, para o plantio misto, a quantidade é de 12,2 $\mathrm{Mg} \mathrm{ha}^{-1}$ (LACLAU et al., 2008).

A mistura de serapilheira com diferentes qualidades e a presença de um material com maior concentração de $\mathrm{N}$ têm determinados efeitos durante a decomposição do consórcio, 
como: (1) o material de alta qualidade, ao se decompor mais rapidamente, transfere nutrientes para o material de baixa qualidade; assim, há um aumento na decomposição da espécie não fixadora; (2) o estímulo ou a inibição de um componente específico, como os polifenóis; (3) a modificação do microclima ou da diversidade do habitat, pela formação da camada de serapilheira mais diversificada, com folhas de diferentes tamanhos, estruturas superficiais e cores, além de organização geométrica e capacidade de retenção e captação de água distintas; (4) os efeitos sinérgicos ou os antagônicos da interação através dos níveis tróficos (HÄTTENSCHIWILER; TIUNOV; SCHEU, 2005).

Em estudo realizado na Austrália sobre um plantio misto de Eucalyptus globulus e Acacia mearnssi, Xiang e Bauhus (2007) observaram que a inserção da leguminosa acelerou a decomposição inicial da mistura de serapilheira. Neste estudo, o decaimento do resíduo de eucalipto na mistura foi mais rápido do que a serapilheira pura desta espécie. O consórcio também influenciou na maior concentração de $\mathrm{N}$ nas folhas do eucalipto, à medida que se aumentou a densidade de leguminosas no povoamento. Entretanto, esse efeito da mistura das duas espécies não alterou o padrão de decomposição do eucalipto. E esses autores complementam: a mudança na velocidade de perda de massa encontrada foi devida a fatores adicionais, como compostos secundários ou mudanças na estrutura de algum substrato na mistura.

Alterações na velocidade de decomposição no consórcio também foram encontradas por Balieiro et al. (2008), no Brasil, entre Eucalyptus grandis e Pseudosamanea guachapele. As taxas de decomposição $(k)$ foram de $0,0047 \mathrm{dia}^{-1}$ para a leguminosa, 0,0032 $\mathrm{dia}^{-1}$ para eucalipto e o valor intermediário de 0,0038 $\mathrm{dia}^{-1}$ para a mistura. Esses valores confirmam o comportamento da manta orgânica sobre o solo, ou serapilheira em decomposição, no consórcio, com valores intermediários entre a maior quantidade para o eucalipto e menor para a leguminosa, apesar de não haver diferença na quantidade de serapilheira depositada (BALIEIRO et al., 2004).

Os povoamentos de A. mangium, em relação aos de E. grandis, no Estado do Espírito Santo, apresentaram maiores teores e estoques de carbono e nutrientes, menor relação $\mathrm{C} / \mathrm{N}$ das folhas e foram responsáveis pela maior quantidade de matéria orgânica e nutrientes incorporados no solo (GARAY et al., 2003). Em estudo realizado na região sul da China com monoculturas de Acacia mangium, Eucalyptus citriodora, Acacia auriculiformis e Schima superba, e as espécies nativas Schima wallichii e Castanopsis hytrix, Wang et al. (2010) encontraram que os valores de MO na camada superficial do solo nas espécies do gênero Acacia foram maiores do que para espécies nativas e também para não leguminosas, seguindo 
o mesmo padrão para os valores de nitrogênio total no solo (WANG et al., 2010). Estes resultados confirmam a eficiência em reconstituir os horizontes orgânicos do solo com o uso de espécies de leguminosas.

A adição de $\mathrm{N}$ também ocasiona efeitos negativos na decomposição em espécies com baixa relação $\mathrm{C} / \mathrm{N}$. A adição de $\mathrm{N}$ em espécies com altas concentrações de $\mathrm{N}$, como as leguminosas, diminuiu a liberação de $\mathrm{CO}_{2}$ (relacionado à taxa de decomposição), mas a adição de $\mathrm{N}$ acelerou a decomposição de espécies não leguminosas. Mesmo sem a adição de $\mathrm{N}$, a decomposição de leguminosas foi menor do que a das não-leguminosas (LI et al., 2001). Em trabalho de Balieiro et al. (2004), também foi observada a baixa velocidade de decomposição para leguminosas, sendo que a A. mangium formou uma grande quantidade de serapilheira sob o solo após cinco anos de plantio (BALIEIRO et al., 2004).

As leguminosas influenciam na taxa de mineralização e na forma predominante de N. Em trabalho desenvolvido em área de plantio misto sem uso de fertilização, em Itatinga$\mathrm{SP}$, a quantidade de $\mathrm{N}$ mineralizada para espécies fixadoras atingiu o dobro do valor, passando de $63 \mathrm{~kg}$ de $\mathrm{N} \mathrm{ha}^{-1}$ ano $^{-1} \mathrm{em} \mathrm{E}$. grandis para $123 \mathrm{~kg} \mathrm{de} \mathrm{N} \mathrm{ha}^{-1}$ ano $^{-1} \mathrm{em} \mathrm{A}$. mangium (VOIGTLAENDER et al., 2011). Li et al. (2001) encontraram nas espécies leguminosas o predomínio de nitrato e, nas não leguminosas, o de amônio.

\subsection{A transferência de nitrogênio na serapilheira}

$\mathrm{O}$ ciclo do $\mathrm{N}$ durante a decomposição da $\mathrm{MO}$ envolve a formação do $\mathrm{N}$ mineral e, concomitantemente, a sua imobilização. Os microrganismos quimiorganotróficos utilizam compostos orgânicos como fontes de C e liberam o íon amônio, que é reincorporado em outros compostos orgânicos celulares (NEVES, 1992). A imobilização é considerada um mecanismo de decréscimo do $\mathrm{N}$ mineral disponível no solo; entretanto, pode reduzir as perdas de $\mathrm{N}$ que ocorrem por lixiviação e prolongar a permanência do elemento no perfil serapilheira-solo.

A imobilização biológica do $\mathrm{N}$ está sujeita à sincronia entre a velocidade e a quantidade de $\mathrm{N}$ liberado durante a decomposição, e a absorção deste pela cultura e a capacidade de imobilização, além das interações entre a comunidade microbiana atuante no ciclo do N. Desta maneira, a imobilização de N em uma mistura de folhas é considerada um indicador de interação microbiana na decomposição de determinado material vegetal e/ou em mistura química do material. (SCHWENDENER et al., 2005). 
O processo de deposição de $\mathrm{N}$ a partir de uma espécie - e posteriormente utilizado em outra - é a transferência de nitrogênio (JENSEN, 1996). A transferência de N é um dos fundamentos mais importantes do plantio consorciado entre espécies fixadoras de $\mathrm{N}$ com espécies não fixadoras de $\mathrm{N}$, e pode ocorrer pela liberação do $\mathrm{N}$ nos nódulos das raízes, pela decomposição de nódulos mortos e pelas raízes, via serapilheira ou translocação via hifas micorrízicas (HE et al., 2009).

Para a transferência de $\mathrm{N}$ ocorrer via decomposição da serapilheira, o $\mathrm{N}$ fixado é primeiramente utilizado apenas pelas espécies fixadoras e torna-se disponível ao ecossistema durante a decomposição do material vegetal sob o solo; entretanto, este é um processo em longo prazo (KHANNA, 1998).

A mistura de materiais com diferentes composições, assim como no plantio consorciado, pode direcionar padrões durante a transferência de $\mathrm{N}$ via decomposição da serapilheira: a teoria da fonte e a teoria da difusão. A teoria de que a fonte controla a quantidade de N disponível ao sistema (SCHIMEL; HÄTTENSCHWILER, 2007) é baseada na teoria da mineralização: os microrganismos responsáveis pela mineralização da $\mathrm{MO}$, por estarem em contato diretamente com o $\mathrm{N}$ mineralizado, teriam acesso primeiramente ao N. Portanto, a disponibilidade de $\mathrm{N}$ para os demais organismos é controlada pelos microrganismos em contato com a fonte (SCHIMEL; BENNETT, 2004). Na teoria da difusão (HILLEL, 1998), o movimento de $\mathrm{N}$ é direcionado por um gradiente de $\mathrm{N}$ entre a fonte e o dreno, influenciado também pela distância entre estes.

Ao parear folhas de diferentes qualidades (com alta concentração e baixa concentração de $\mathrm{N}$ ) durante a decomposição, a composição química das folhas de menor concentração de $\mathrm{N}$ limitou o crescimento microbiano e controlou as taxas de transferência de N (SCHIMEL; HÄTTENSHWILER, 2007) Assim, o controle da quantidade de N disponível no sistema de decomposição foi realizado apenas pela quantidade de $\mathrm{N}$ inicial das folhas. Além de direcionar a transferência, a mistura de um material de alta qualidade com o de baixa qualidade é capaz de reter o $\mathrm{N}$ disponível na serapilheira sob o solo por algumas semanas (SCHWENDENER et al., 2005). A mistura pode regular a liberação de N, mas não altera a decomposição e nem a mineralização de $\mathrm{N}$ das espécies individuais.

Além disso, a transferência de nutrientes também ocorre no sistema solo- serapilheira. Os fungos, por meio de seus filamentos, são capazes de estimular a translocação de $\mathrm{N}$ do solo para o material vegetal, sendo que à medida que a quantidade de $\mathrm{N}$ aumenta no solo, aumenta também na serapilheira (FREY; SIX; ELLIOTT, 2003). 


\subsubsection{O uso da técnica isotópica no ciclo do nitrogênio}

Um mesmo elemento pode ter número de prótons iguais e diferente número de nêutrons, o que resulta no mesmo número atômico e distinto número de massa. Esses elementos são denominados isótopos, classificados em radioisótopos - os que mudam de massa por emissão de energia ou partículas subatômicas - e em isótopos estáveis, que não alteram sua massa ao longo do tempo. Os isótopos com menor massa atômica normalmente são os mais abundantes e os de maior massa são mais raros. Os dois isótopos estáveis do N, de pesos atômicos 14 e 15, possuem porcentagens constantes na atmosfera de $99,635 \%$ e 0,365\%, respectivamente (JUNK; SVEC, 1958). Através da razão isotópica entre concentração do isótopo raro $\left({ }^{15} \mathrm{~N}\right)$ e o mais abundante $\left({ }^{14} \mathrm{~N}\right)$, em comparação a um padrão (o ar atmosférico para o $\mathrm{N}$ ), é determinada a abundância isotópica de determinado material (TRIVELIN et al., 1973).

O isótopo estável ${ }^{15} \mathrm{~N}$ é usado como método para avaliar as transformações que o $\mathrm{N}$ pode passar durante seu ciclo. O método marca o caminho dos dois isótopos de $\mathrm{N}\left({ }^{15} \mathrm{~N}\right.$ e $\left.{ }^{14} \mathrm{~N}\right)$ simultaneamente, fornecendo informações acerca do sistema e estimando as taxas de transformação do N. O ciclo do nitrogênio no sistema solo-planta-atmosfera é estudado com ferramentas isotópicas na área agronômica (TRIVELIN et al., 2002) e ambiental (PICCOLO et al., 1996; GARTEN; IVERSEN, NORBY, 2011).

A técnica da abundância natural de ${ }^{15} \mathrm{~N}$, usualmente denominada $\delta^{15} \mathrm{~N}$ (\%) (SHEARES; KOHL, 1986), é uma das maneiras de utilizar o isótopo ${ }^{15} \mathrm{~N}$. Um dos principais problemas está na interpretação dos valores de $\delta^{15} \mathrm{~N}$, pois em cada processo do ciclo do $\mathrm{N}$ (fixação, nitrificação, imobilização e desnitrificação) há um valor específico de fracionamento isotópico (BODDEY et al., 2000). Entretanto, é possível conhecer a variação de $\delta^{15} \mathrm{~N}$ entre os ecossistemas e entre as plantas como uma ferramenta interessante para estudos de fisiologia e nutrição vegetal (MARSHALL; BROOKS; LAJTHA, 2007). Em estudo de caracterização de solo e serapilheira em floresta tropical, Martins (2010) notou diferentes valores de $\delta^{15} \mathrm{~N}$ para a vegetação e para o solo, de acordo com o gradiente altitudinal da Mata Atlântica. O solo reflete o sinal isotópico da vegetação presente e vice-versa, em função dos mecanismos de liberação de $\delta^{15} \mathrm{~N}$ da serapilheira para a matéria orgânica do solo. Esse autor também notou enriquecimento de $\delta^{15} \mathrm{~N}$ no perfil do solo, visto que a vegetação diminui a composição isotópica no perfil serapilheira-solo. Rachid (2010) estudou a variação de $\delta^{15} \mathrm{~N}$ no solo em diferentes usos e notou enriquecimento dos valores, mesmo em solos onde houve 
fixação biológica de $\mathrm{N}$, sugerindo pequeno uso do $\mathrm{N}$ que teve como origem a fixação biológica.

A técnica de diluição isotópica é outro modo para o uso de isótopos. Utilizam-se compostos de razão isotópica $\left({ }^{15} \mathrm{~N} /{ }^{14} \mathrm{~N}\right)$ conhecida e diferente da natural, e em seguida é avaliada a composição do sistema de estudo. O enriquecimento isotópico é bastante utilizado em pesquisa na área de ciências agronômicas, como fertilidade do solo e nutrição de plantas, entre outras, pois conhecendo a concentração no material enriquecido, é possível descriminar a quantidade de $\mathrm{N}$ proveniente deste material e das outras fontes (TRIVELIN et al., 1998, GAVA et al., 2003, FENILLI et al., 2007). A variação do enriquecimento dos compostos depende do objetivo a ser avaliado, como, por exemplo, 0,5 átomos \% de ${ }^{15} \mathrm{~N}$ para estimar a FBN em plantio consorciado (BOUILLET et al., 2008), de 5 a 10 átomos\% de ${ }^{15} \mathrm{~N}$ para transferência de N na decomposição de folhas (FREY; SIX; ELLIOTT, 2003, SCHWENDENER et al., 2005) e de até 99 átomos $\%$ de ${ }^{15} \mathrm{~N}$ para transferência de $\mathrm{N}$ por meio de fungos micorrízicos (HE et al., 2009).

As ferramentas isotópicas no plantio consorciado têm ampla utilização, tanto a técnica de abundância quanto a de enriquecimento. A quantificação da FBN pelo método de abundância natural considera que a espécie fixadora possui como fonte de $\mathrm{N}$ o solo e também o ar atmosférico, enquanto a espécie controle, a não fixadora, apenas o solo. Assim, os valores de $\delta^{15} \mathrm{~N}$ quando há FBN varia de 0 a 2\%o (HÖGBERG, 1997). Coelho et al. (2007) encontraram nas leguminosas do plantio consorciado valores mais altos de $\delta^{15} \mathrm{~N}$ do que as espécies não fixadoras, o que indica possível ineficiência desta técnica para quantificar a FBN. O método de diluição isotópica é o mais indicado e tem o mesmo princípio de diferentes fontes para a espécie fixadora; entretanto utiliza-se de fertilizantes enriquecidos com ${ }^{15} \mathrm{~N}$ como fonte de $\mathrm{N}$ no solo e, à medida que ocorre a FBN, há uma diluição isotópica na espécie leguminosa (HE; CRITCHLEY; BLEDSOE, 2003). Na comparação entre as técnicas isotópicas, o método de diluição (enriquecimento) isotópico apresentou-se mais eficiente em comparação à abundância natural para avaliar a quantidade de $\mathrm{N}$ fixado em plantio misto de A. mangium e E. grandis, novamente em função de a planta referência apresentar baixos valores de $\delta^{15} \mathrm{~N}$ no método de abundância (BOUILLET et al., 2008).

As duas técnicas descritas podem ser usadas também nos estudos da transferência de N. He et al. (2005) utilizaram compostos enriquecidos de ${ }^{15} \mathrm{~N}$ para obter informações sobre a transferência de $\mathrm{N}$ em diferentes condições das fontes: a espécie fixadora $\mathrm{N}$ e a espécie não fixadora $\mathrm{N}$, com e sem a inoculação de nódulos. A transferência de $\mathrm{N}$ foi maior na presença de nódulos também quando a fonte de $\mathrm{N}$ foi ${ }^{15} \mathrm{NH}_{4}{ }^{+}$em vez de ${ }^{15} \mathrm{NO}_{3}^{-}$(HE et al., 2005). 
O método de abundância natural apresenta algumas vantagens por ocasionar poucos impactos no sistema solo-planta em relação à adição de $\mathrm{N}$ externo ao sistema, os fertilizantes enriquecidos, para depois serem transferidos (HE et al., 2009). Sierra et al. (2009), ao compararem as duas técnicas isotópicas na transferência de $\mathrm{N}$ entre espécies $\mathrm{N}$-fixadoras e N-não fixadoras através de exsudados radiculares, observaram que a maior parte do ${ }^{15} \mathrm{~N}$ adicionado no solo permaneceu abaixo das árvores e apenas $0,17 \%$ foi liberado pelos exsudados. Entretanto, esses autores também encontraram dificuldades na interpretação dos valores de $\delta^{15} \mathrm{~N}$, pois, dependendo da quantidade de $\mathrm{N}$ fixada, surgem variações nos valores de $\delta^{15} \mathrm{~N}$ (SIERRA et al., 2009). As dificuldades de interpretação dos valores de $\delta^{15} \mathrm{~N}$ também ocorrem na transferência de $\mathrm{N}$ por meio de fungos micorrízicos, já que o movimento de $\mathrm{N}$ entre plantas e fungos é bidirecional (HOOBIE; HOBBIE, 2006).

A transferência de $\mathrm{N}$ entre diferentes tipos de material vegetal durante a decomposição é estudada por meio de compostos enriquecidos de ${ }^{15} \mathrm{~N}$ (FREY; SIX; ELLIOTT, 2003; SCHIMEL; HÄTTENSCHWILER, 2007). Schwendener et al. (2005) pesquisaram a decomposição de uma mistura de folhas com diferentes qualidades - da leguminosa Gliricidia sepium, considerada de alta qualidade, e do cupuaçu (Theobroma graniflorum), considerada de baixa qualidade - por meio do enriquecimento das folhas de G. sepium. $\mathrm{O}$ aumento nos valores de ${ }^{15} \mathrm{~N}$ nas folhas de menor qualidade e no solo foi encontrado por causa da liberação de $\mathrm{N}$ pelas folhas de maior qualidade e da transferência do elemento para o solo, sendo imobilizado pelas folhas de menor qualidade. O uso de isótopos em estudos sobre decomposição de serapilheira também permite quantificar a mineralização da matéria orgânica e o incorporação de N externo ao material em decaimento (ZELLER et al., 2000). Além disso, é possível monitorar a incorporação do $\mathrm{N}$ liberado durante a decomposição na biomassa microbiana, nas raízes através das micorrizas, e a transferência do elemento para a planta (ZELLER et al., 2001). 


\section{MATERIAL E MÉTODOS}

\section{1 Área de estudo}

O presente trabalho foi conduzido na Estação Experimental de Itatinga, vinculada ao Departamento de Ciências Florestais da Escola Superior de Agricultura "Luiz de Queiroz" (ESALQ), localizada no município de Itatinga-SP, pertencente à Universidade de São Paulo (USP), no Estado de São Paulo. A Estação está localizada no Planalto Ocidental de São Paulo $\left(23^{\circ} 02^{\prime} 01^{\prime \prime} \mathrm{S}\right.$ e $\left.48^{\circ} 38^{\prime} 34^{\prime \prime} \mathrm{O}\right)$, com topografia levemente ondulada.

A Estação possui 675 hectares, inicialmente ocupados com a vegetação nativa local, o cerrado. Desde 1945, o principal uso da terra é de monoculturas de Eucalyptus sp. e Pinus sp., com alguns fragmentos de cerrado.

O solo da área experimental (Tabela 1) é classificado como Latossolo VermelhoAmarelo Distrófico textura média (EMBRAPA, 1999).

Tabela 1. Características químicas do solo da área experimental (Bouillet et al.,2012- dados não publicados)

\begin{tabular}{cccccc}
\hline Profundidade $(\mathrm{cm})$ & $\mathrm{pH}$ água & $\begin{array}{c}\mathrm{T} \\
\mathrm{mmol}_{\mathrm{c}}\end{array}$ & $\begin{array}{c}\mathrm{S} \\
\mathrm{dm}^{-3 . .}\end{array}$ & $\begin{array}{c}\mathrm{CO} \\
\mathrm{g} \mathrm{dm}^{-3}\end{array}$ & $\begin{array}{c}\text { Argila } \\
\mathrm{g} \mathrm{kg}^{-1}\end{array}$ \\
\hline $0-5$ & 5,50 & 17,60 & 9,60 & 35,00 & 114,00 \\
$50-100$ & 5,80 & 5,80 & 0,20 & 7,00 & 161,00 \\
$200-300$ & 5,70 & 2,10 & 0,20 & 4,00 & 161,00 \\
\hline
\end{tabular}

pH água: Relação solo-água 1:2,5; P e K: Extrator Mehlich-1 e calorimetria; S: Soma de bases $\mathrm{Ca}, \mathrm{Mg}$ e $\mathrm{K}$ com extrator $\mathrm{KCl} 1 \mathrm{~mol} \mathrm{~L}^{-1}$; T: Capacidade de troca de cátions a $\mathrm{pH}$ 7,0; $\mathrm{CO}$ : Carbono orgânico determinado pelo método Walkey-Black; Argila: Método da pipeta.

O local apresenta clima mesotérmico úmido (Cwa), classificação de Köppen, com precipitação entre os meses secos de 30 a $60 \mathrm{~mm}$. Entre os meses de junho e setembro, ocorre a estação fria com temperatura média de $12,5^{\circ} \mathrm{C}$ e média anual de $19{ }^{\circ} \mathrm{C}$. A umidade relativa média anual é de $71 \%$ com precipitação média anual de $1360 \mathrm{~mm}$. A temperatura e a precipitação pluviométrica médias do período de dez anos (2000 a 2010) e do período estudado (outubro de 2010 a dezembro de 2011) estão apresentadas nas Figuras 1 e 2, respectivamente. 


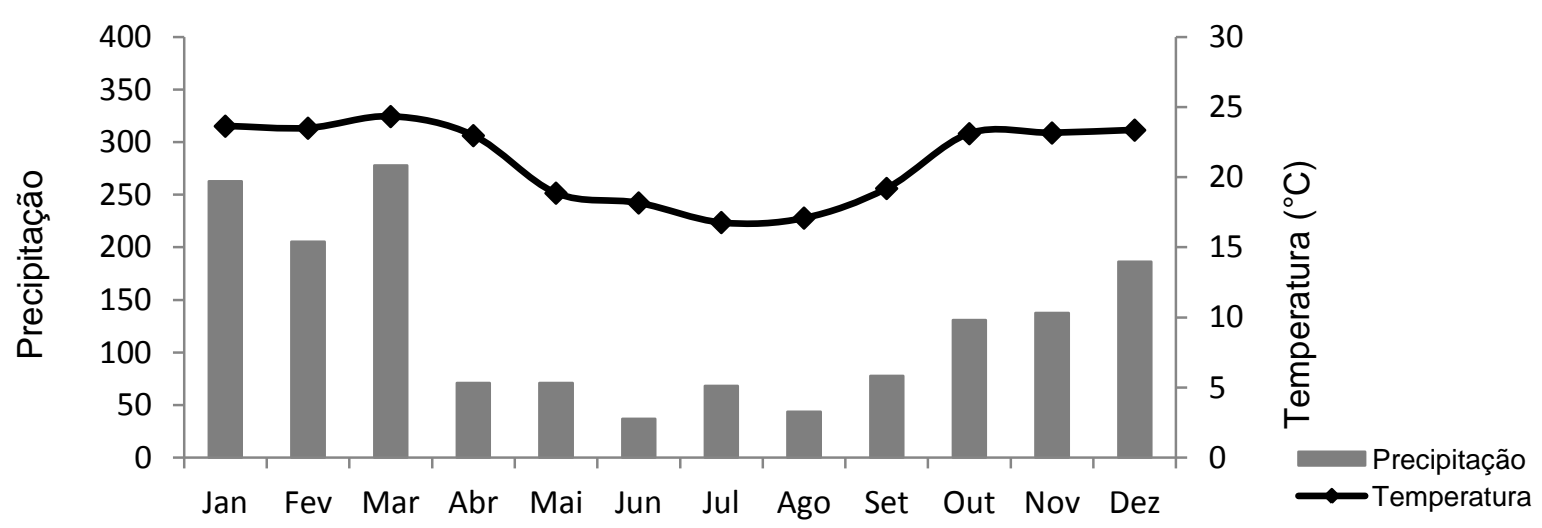

Figura 1 - Temperatura e precipitação pluviométrica médias na Estação Experimental de Itatinga no período de dez anos (2000 a 2010)

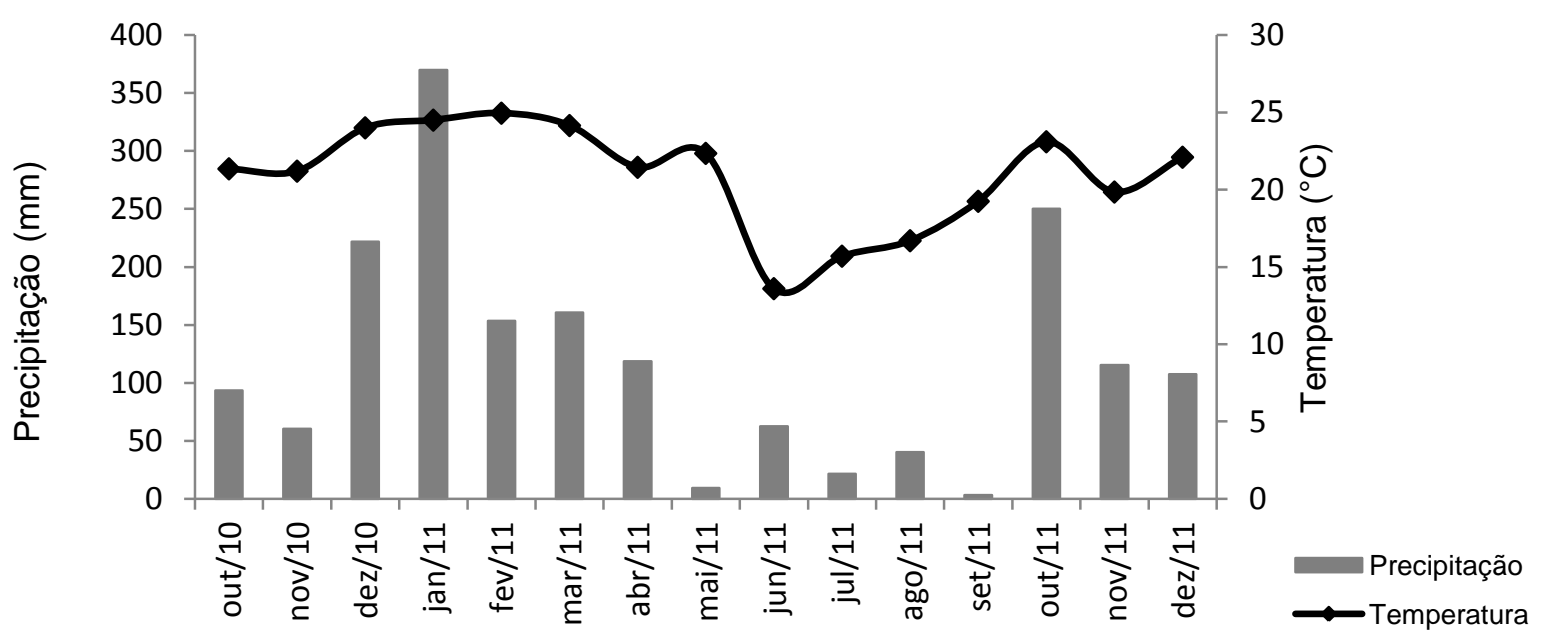

Figura 2 - Temperatura e precipitação pluviométrica médias na Estação Experimental de Itatinga no período estudado (outubro de 2010 a dezembro de 2011)

O trabalho foi desenvolvido em parcelas de monoculturas de Eucalyptus grandis, de Acacia mangium e de plantações mistas nas proporções 50A:50E. Essas parcelas encontraram-se na segunda rotação experimental de consórcio de Eucalyptus grandis com Acacia mangium, o qual teve a primeira rotação em maio de 2004 e a final em maio 2009. A segunda rotação constituiu-se de parcelas nas mesmas composições que as anteriores e iniciou-se em novembro de 2009. Ao lado da área experimental, foram instaladas parcelas de Acacia mangium com primeira rotação de plantio, o que proporcionou parcelas com solos em diferentes condições: primeira e segunda rotação com leguminosa. As mudas de acácias utilizadas para a primeira e a segunda rotações foram inoculadas com cepas de rizobium 
selecionadas pela EMBRAPA (Rio de Janeiro-RJ). Toda a área em que o trabalho foi realizado esteve anteriormente com plantio de eucalipto por mais de 60 anos.

O trabalho constituiu-se de dois experimentos de decomposição, realizados separadamente. O Experimento A foi realizado entre outubro de 2010 e outubro de 2011, nas parcelas puras de eucalipto, de acácia na primeira rotação e de acácia na segunda rotação. $\mathrm{O}$ experimento $\mathrm{B}$ foi executado nas parcelas mistas de eucalipto e acácia, entre dezembro de 2010 e dezembro de 2011.

\subsection{Experimento A: Teoria da Vantagem Doméstica}

O Experimento A, baseado na Teoria da Vantagem Doméstica (Home Field Advantage), avaliou a hipótese de que a decomposição de serapilheira ocorre mais rapidamente na presença da biota do solo da própria espécie de planta do que na presença da biota de solos de outras espécies. As espécies estudadas foram eucalipto (Eucalyptus grandis) e acácia (Acacia mangium).

\subsubsection{Preparo das bolsas de decomposição de serapilheira e raízes}

Para avaliar a decomposição de folhas e raízes no experimento A - Teoria da Vantagem Doméstica, em povoamentos puros de Eucalyptus e A. mangium, foi utilizado o método direto no campo (in situ), com uso de bolsas de decomposição ou litterbags, como são comumente conhecidas. Este é um método de avaliação direta da perda de massa do material vegetal (BÄRLOCHER, 2005), pois é baseado em bolsas de malha contendo quantidade conhecida de material vegetal, expostas em campo por determinado período de tempo e retiradas, posteriormente, para análise direta da decomposição (COLEMAN; CROSSLEY; HENDRIX, 2004). 
a)

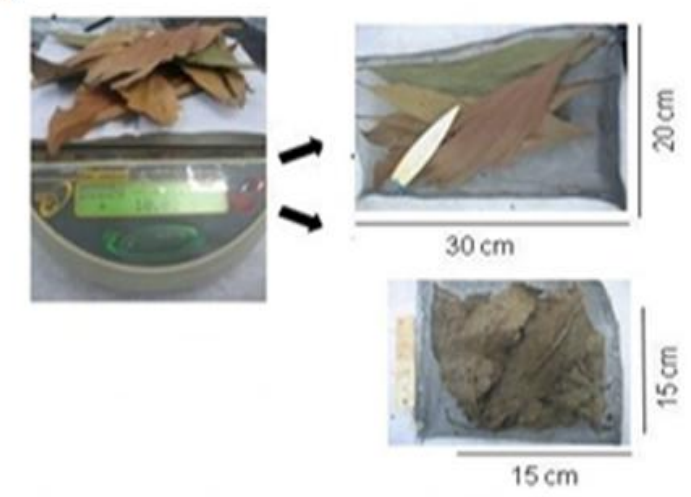

b)

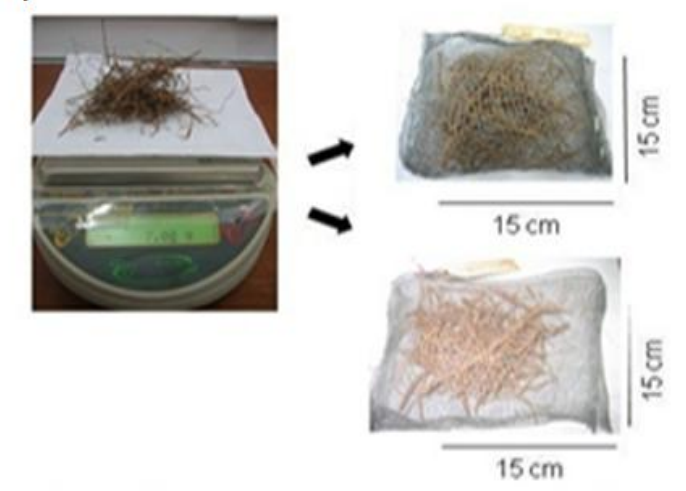

Figura 3 - Confecção das bolsas de decomposição utilizadas do Experimento A: a) bolsas de folhas nas dimensões de $20 \times 30 \mathrm{~cm}$ para acácia e $15 \times 15 \mathrm{~cm}$ para eucalipto, com $10 \mathrm{~g}$ de material cada; b) bolsas de raízes nas dimensões de $15 \times 15 \mathrm{~cm}$ para acácia e eucalipto, contendo $7 \mathrm{~g}$ de material cada bolsa

As bolsas para este trabalho foram de polietileno, por ser um material resistente e flexível, que contorna a forma da serapilheira. A malha utilizada possui tamanho de $2 \mathrm{~mm}$, o que permitiu o acesso apenas da mesofauna ao interior das bolsas (SWIFT; HEAL; ANDERSON, 1979). Duas dimensões diferentes de bolsas foram confeccionas: (1) $0,15 \times 0,15$ m para folhas de Eucalyptus e raízes de Eucalyptus e A. mangium, e (2) 0,30 × 0,20 m para folhas de A. mangium (Figura 3). O interior de cada bolsa de folhas foi preenchido com aproximadamente $10 \mathrm{~g}$ folhas e $7 \mathrm{~g}$ de raízes. As folhas utilizadas foram senescentes e coletadas na serapilheira, e as raízes finas (diâmetro $<2 \mathrm{~mm}$ ) foram coletadas na camada superficial do solo. Todo o material utilizado foi retirado de parcelas de eucalipto e acácia no final de rotação. Este material utilizado foi seco ao ar livre e posteriormente colocado dentro das bolsas.

\subsubsection{Delineamento experimental A}

O delineamento experimental A (Figura 4) é constituído de três blocos com três parcelas cada, com total de nove áreas. A composição das parcelas é:

E: $100 \%$ de E. grandis (0A: 100E)

2R: $100 \%$ de A. mangium na segunda rotação (100A2R:0E)

1R: $100 \%$ de A. mangium na primeira rotação (100A1R:0E).

Em cada parcela, foram colocadas bolsas de decomposição nas seguintes composições: 
FE: $100 \%$ folhas de eucalipto (0A:100E);

FA: $100 \%$ folhas de acácia (100A:0E);

RE: $100 \%$ raízes de eucalipto (0A:100E) ;

RA: $100 \%$ raízes de acácia (100A:0E).

A combinação das parcelas com a composição das bolsas de decomposição teve os seguintes tratamentos:

FEE: folhas de eucalipto na parcela $100 \%$ de E. grandis;

FE1R: folhas de eucalipto na parcela $100 \%$ de A. mangium na primeira rotação;

FE2R: folhas de eucalipto na parcela $100 \%$ de A. mangium na segunda rotação;

FAE: folhas de acácia na parcela $100 \%$ de E. grandis;

FA1R: folhas de acácia na parcela $100 \%$ de A. mangium na primeira rotação;

FA2R: folhas de acácia na parcela $100 \%$ de A. mangium na segunda rotação;

REE: raízes de eucalipto na parcela $100 \%$ de E. grandis;

RE1R: raízes de eucalipto na parcela $100 \%$ de A. mangium na primeira rotação;

RE2R: raízes de eucalipto na parcela $100 \%$ de A. mangium na segunda rotação;

RAE: raízes de acácia na parcela $100 \%$ de E. grandis;

RA1R: raízes de acácia na parcela $100 \%$ de A. mangium na primeira rotação;

RA2R: raízes de acácia na parcela $100 \%$ de A. mangium na segunda rotação.

Neste experimento, foram monitoradas 432 bolsas de decomposição (12 tratamentos, 9 repetições e 4 coletas), com total de 72 bolsas por parcela. 


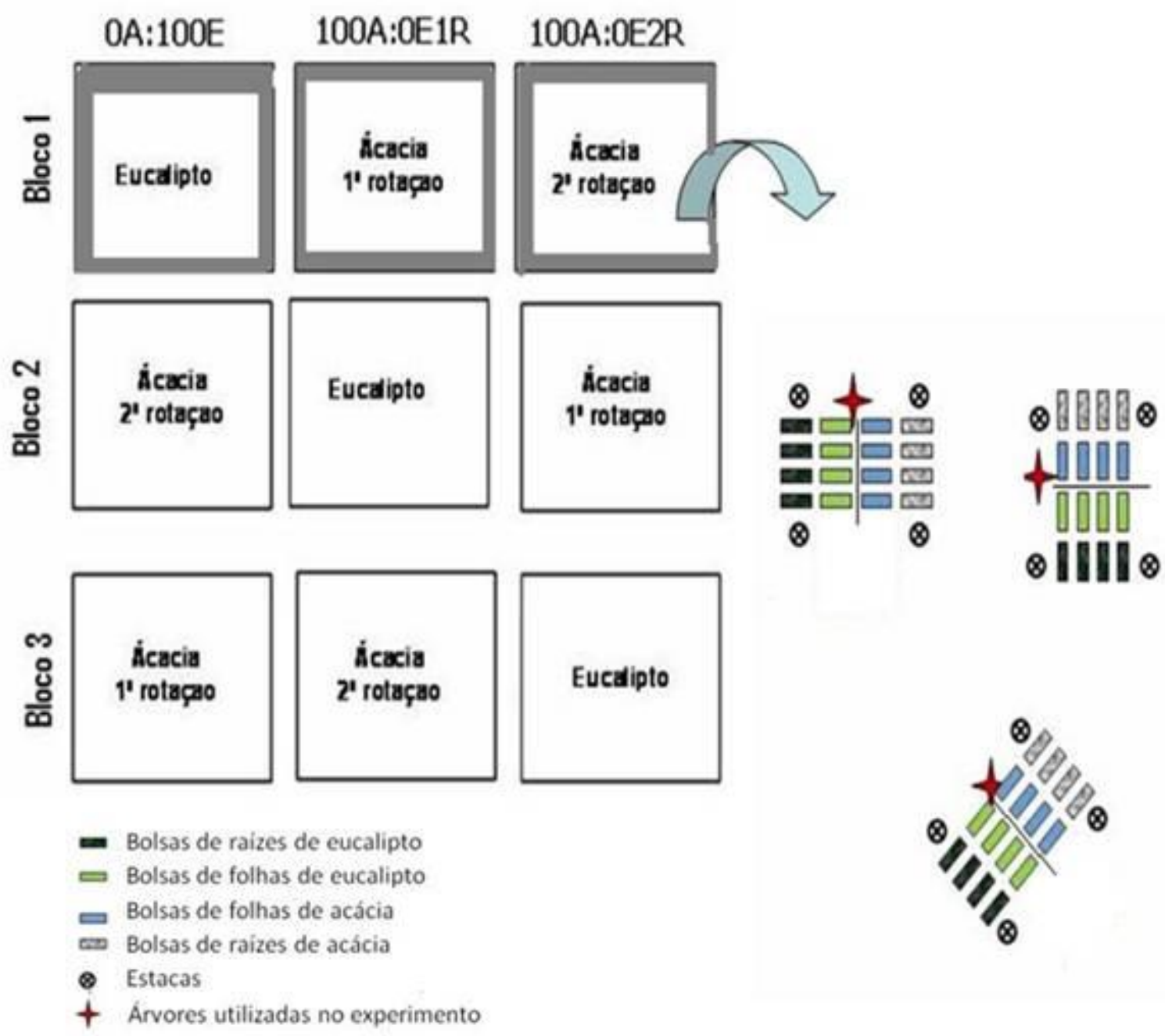

Norte

Figura 4 - Delineamento do Experimento A para o estudo da decomposição de folhas e raízes de E. grandis e A. mangium. Três árvores por parcela foram escolhidas para a disposição das bolsas de decomposição

As bolsas de serapilheira com folhas foram dispostas sobre o solo (Figura 5), retirando apenas os galhos de maior dimensão e preservando a serapilheira já existente. Uma divisória foi enterrada a $5 \mathrm{~cm}$ de profundidade para evitar contaminação por meio de micélios entre o material de E. grandis e A. mangium. Grampos metálicos foram utilizados para fixar as bolsas no solo e mantê-las na disposição desejada. As bolsas contendo raízes foram enterradas a $5 \mathrm{~cm}$ de profundidade. 


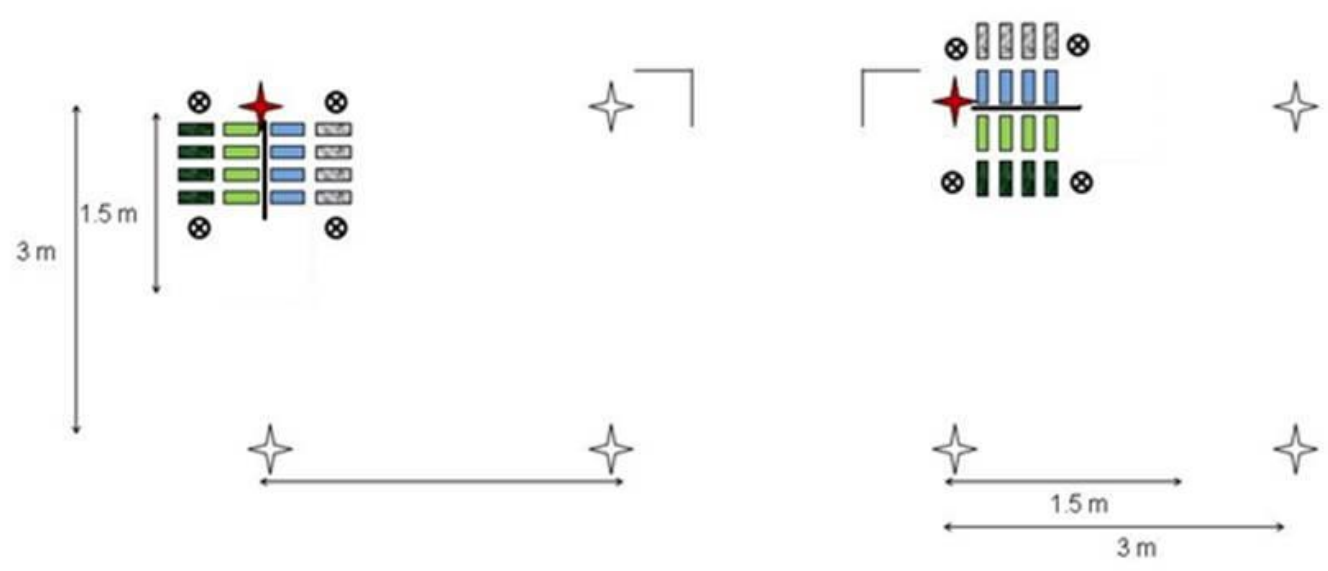

- Bolsas de raízes de eucalipto

- Bolsas de folhas de eucalipto

Bolsas de folhas de acácia

Bolsas de raízes de acácia

(2) Estacas

$\downarrow$ Árvores não utilizadas no experimento

+ Árvores utilizadas no experimento

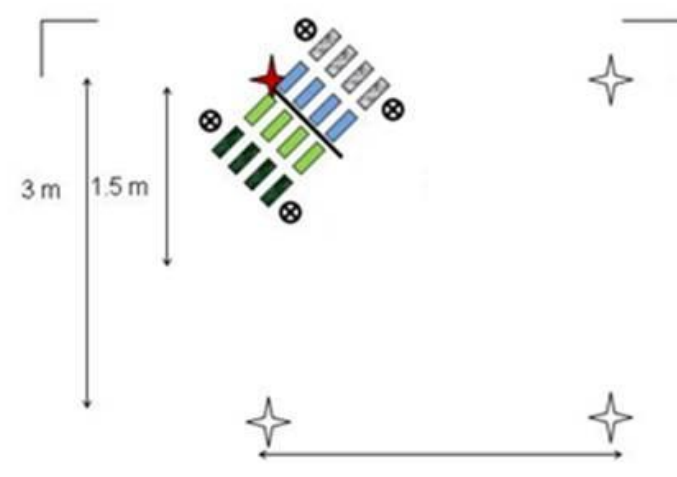

Norte

Figura 5 - Disposição espacial das bolsas de serapilheira para cada parcela do Experimento A - Teoria da vantagem doméstica, em outubro de 2010. As bolsas foram dispostas em três direções diferentes, com uma divisória de separação entre os tipos diferentes de folhas 


\subsubsection{Instalação e coleta das bolsas de decomposição}

O experimento da Teoria da Vantagem Doméstica foi instalado em outubro de 2010 e teve duração até outubro de 2011 (Figura 6).
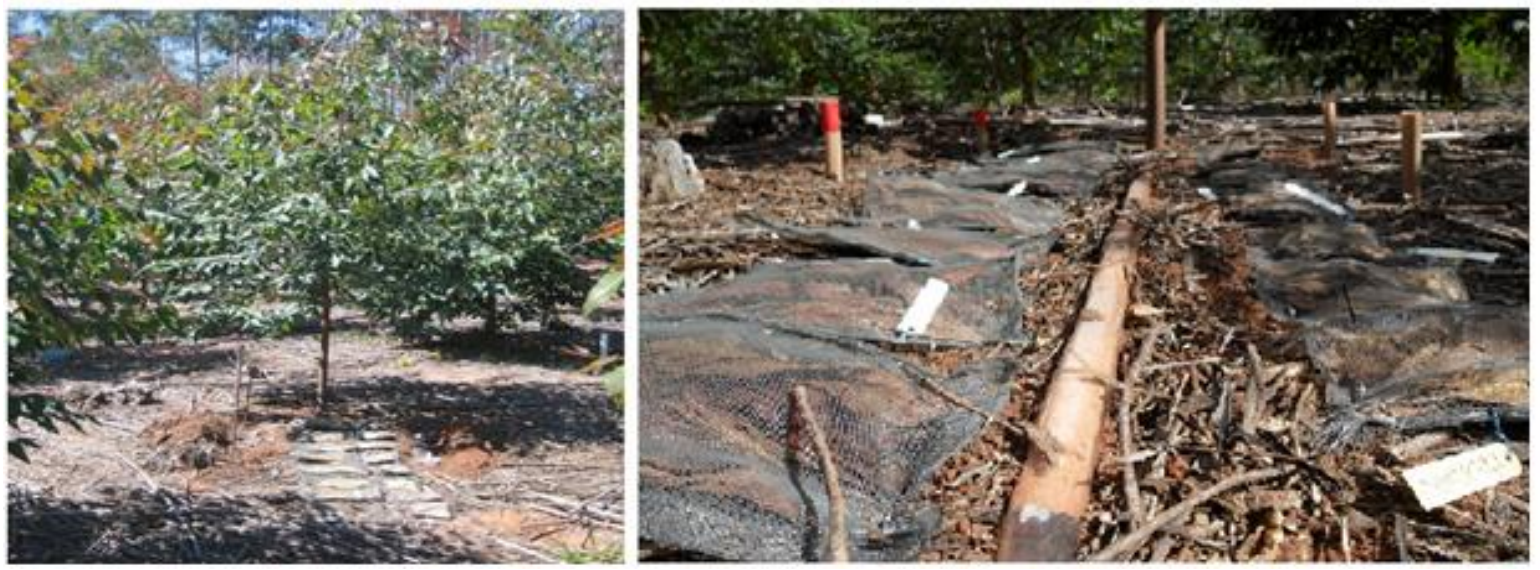

Figura 6 - Instalação do experimento em outubro de 2010 em E. grandis puro (E), em A. mangium puro ( $2 \mathrm{R}$ ) e adicionalmente na primeira rotação de A. mangium puro $(1 \mathrm{R})$

As coletas das bolsas de decomposição do Experimento A foram realizadas a cada três meses, a partir da instalação do experimento em outubro de 2010. As datas de coletas foram em janeiro, abril, julho e outubro de 2011, e corresponderam, respectivamente, a 92, 181, 275 e 367 dias após a instalação do experimento. Em cada coleta, foram retiradas nove bolsas ao acaso, por data, para todos os tratamentos.

\subsubsection{Preparo e análise das amostras de serapilheira e raízes}

Inicialmente, foi determinada a umidade das folhas e raízes utilizando-se a massa fresca de nove amostras e, posteriormente, a massa seca. Todas as amostras foram secas a 65 ${ }^{\circ} \mathrm{C}$ (folhas por 4 dias e raízes por 7 dias), exceto para as análises de celulose, hemicelulose e lignina, em que as amostras foram secas a $40{ }^{\circ} \mathrm{C}$ e posteriormente moídas e homogeneizadas. A correção da contaminação mineral do solo no material das bolsas foi realizada com amostras de compostos por tratamento e bloco, por meio da determinação do teor de cinzas no Departamento de Ciências Florestais, Laboratório de Ecologia Aplicada ESALQ/USP. A porcentagem de cinzas foi considerada pela quantidade de material restante nas amostras após $4 \mathrm{~h}$ em mufla a $450{ }^{\circ} \mathrm{C}$, para eliminação da MO. 


\section{- Teores de carbono, nitrogênio e enxofre}

Os teores de carbono (C) e nitrogênio (N) totais das folhas e raízes foram determinados por combustão a seco nos equipamentos LECO TruSpec Micro CHN, e os teores de enxofre (S) total, no equipamento LECO S-144, no Laboratório de Ciclagem de Nutrientes (CENA-USP).

\section{- Concentração de fósforo e potássio}

As análises para determinação de fósforo $(\mathrm{P})$ e potássio $(\mathrm{K})$ foram realizadas no Departamento de Ciências Florestais, Laboratório de Ecologia Aplicada (ESALQ/USP), por meio do método de decomposição nítrico-perclórica (MALAVOLTA; VITTI; OLIVEIRA, 1989). O teor total de $\mathrm{P}$ foi determinado pelo método/metavanadato de amônio e de K, por espectrofotometria de absorção atômica. Foram utilizadas amostras compostas por tratamento (FAE, FA1R, FA2R, FEE, FE1R, FE2R, RAE, RA1R, RA2R, REE, RE1R e RE2R) e por parcela experimental.

\section{- Caracterização de compostos orgânicos da serapilheira e raízes}

A caracterização dos compostos orgânicos das folhas e raízes foi determinada por amostras compostas de cada tipo de material (FA, FE, RA, RE) no início e no fim do experimento. As análises foram realizadas no Laboratório de Nutrição Animal do CENA/USP.

Os teores de celulose e hemicelulose foram quantificados pelo método de fibras em detergente neutro (FDN) e em detergente ácido (FDA), e de lignina, em detergente ácido (LDA) (VAN SOEST, 1964). Os carboidratos solúveis foram extraídos do material com água fervente, mantidos em banho-maria por $30 \mathrm{~min}$ a $80{ }^{\circ} \mathrm{C}$, e determinados em fotocolorímetro a $510 \mathrm{~nm}$, usando-se solução de fenol a $5 \%$ e $\mathrm{H}_{2} \mathrm{SO}_{4}$ concentrado. $\mathrm{O}$ padrão utilizado foi glicose $1 \%$ (DUBOIS et al., 1956). Os fenóis totais foram extraídos em solução com água destilada, reagende de Folin Ciocalteu e carbonato de sódio, com leitura em espectrofotômetro em absorbância a $725 \mathrm{~nm}$. Os taninos totais foram determinados por diferença entre fenóis após a extração com polivinilpolipirrolidona (PVPP) (MAKKAR et al., 
1993). Para taninos condensados, usou-se reagente butanol- $\mathrm{HCl}$, reagente férrico e leitura da amostra (absorbância $550 \mathrm{~nm}$ ) em espectrofotômetro (PORTER; HRSTICH; CHAN, 1986).

\section{- Índices de qualidade da serapilheira e raízes}

A qualidade do material foi considerada a partir das relações $\mathrm{C} / \mathrm{N}, \mathrm{N} / \mathrm{P}$ e lignina/N. Os índices de susceptibilidade à decomposição foram definidos segundo as equações (1), (2) e (3):

a) Quociente holocelulose / lignocelulose (CORTEZ et al., 1996)

$$
\text { QCL }=\frac{\text { hemicelulose }+ \text { celulose }}{\text { hemicelulose }+ \text { celulose }+ \text { lignina }}
$$

b) Índice ligno-celulósico (MELILLO et al., 1989)

$$
\text { ILC }=\frac{\text { lignina }}{\text { lignina }+ \text { celulose }}
$$

c) Índice de decomponibilidade (HERMANN; McGILL; DORMMAR, 1977)

$$
\text { ID }=\frac{(\mathrm{C} / \mathrm{N}) \times(\% \text { lignina })}{\sqrt{(\% \text { carboidratos })}}
$$

\subsubsection{Análise estatística dos dados}

Os dados de decomposição foram analisados a cada coleta e testados em relação à normalidade e à homogeneidade de variância por meio do teste de Shapiro-Wilk e do modelo de Box-Cox, respectivamente.

Para comparar os efeitos e interações entre as parcelas, os blocos e o tipo de material em relação à perda de massa, à quantidade de $\mathrm{C}$ e nutrientes, foi utilizado um modelo linear 
pelo comando PROC GLM. A diferença entre os tratamentos foi avaliada pelo teste de média de Tukey com nível de significância de 0,05 . Os valores de perda de massa foram transformados utilizando-se a função "Asen (raiz quadrada)".

Os compostos orgânicos foram comparados considerando-se apenas os tipos de materiais: FA e FE; RA e RE. Os valores iniciais e finais dos compostos orgânicos foram comparados entre as datas através do teste T não pareado.

Todos os testes foram realizados empregando-se o pacote estatístico SAS 9.1 (SAS Institute)

\subsection{Experimento B: Transferência Bruta de N na Serapilheira}

O Experimento B - Transferência bruta de $N$ entre folhas de Eucalyptus grandis e Acacia mangium estimou a transferência de $\mathrm{N}$ entre folhas com a mistura de folhas marcadas de Eucalyptus com folhas não marcadas de Acácia, e também o inverso.

A transferência de $\mathrm{N}$ entre E. grandis e A. mangium foi avaliada por meio do método direto no campo (in situ), com uso de bolsas de decomposição.

\subsubsection{Preparo das bolsas de decomposição para transferência}

Bolsas de decomposição foram confeccionadas de polietileno com malha de $2 \mathrm{~mm}$. As bolsas apresentaram dimensões de $0,30 \times 0,20 \mathrm{~m}$ com uma divisória no interior feita com o mesmo material, que permitiu a transferência de $\mathrm{N}$ entre as folhas sem a mistura do material. O interior de cada bolsa foi preenchido com $5 \mathrm{~g}$ de material marcado (E. grandis ou A. mangium) e $5 \mathrm{~g}$ de material não marcado (E. grandis ou A. mangium). As folhas não marcadas foram coletadas na serapilheira de eucalipto e acácia no final de rotação, e as folhas marcadas foram coletadas com uso de redes embaixo das copas. Todo material utilizado foi previamente seco ao ar livre. A umidade inicial das folhas marcadas foi determinada por meio das folhas de acácia marcadas e a umidades das folhas não marcadas foi determinada no Experimento A. 


\subsubsection{Produção das folhas enriquecidas $\mathrm{em}^{15} \mathrm{~N}$}

As folhas marcadas (ou enriquecidas) com ${ }^{15} \mathrm{~N}$ de Eucalyptus e Acacia foram produzidas no campo na Estação Experimental de Itatinga em plantios puros de E. grandis e A. mangium, na primeira rotação experimental do consórcio de eucalipto com acácia, com início de plantio em 2004. A adubação nitrogenada foi realizada com nitrato de amônio $\left(\mathrm{NH}_{4}{ }^{+} \mathrm{NO}_{3}{ }^{-}, 34 \%\right.$ de $\left.\mathrm{N}\right)$ marcado a 10 átomos $\%$ de ${ }^{15} \mathrm{~N}$ ao nitrato. A aplicação ocorreu em 16 árvores $(4 \times 4)$ em dois pontos na base do tronco, na forma de adubo sólido no solo em uma dose única de $500 \mathrm{~g}$ para cada espécie, em maio de 2009.

As folhas senescentes enriquecidas de ${ }^{15} \mathrm{~N}$ foram coletadas no período de dezembro de 2009 a julho de 2010 e, para determinação do enriquecimento isotópico, foram escolhidas quatro amostras mensais: dezembro, fevereiro, abril e junho. Os meses que apresentaram folhas com os maiores enriquecimentos de ${ }^{15} \mathrm{~N}$ foram escolhidos para serem utilizadas estas folhas no experimento de transferência de $\mathrm{N}$ via decomposição. Para acácia: mês de dezembro de 2009 (átomos $\%$ de ${ }^{15} \mathrm{~N}=0,55$ ) e junho de 2010 (átomos $\%$ de ${ }^{15} \mathrm{~N}=0,53$ ). Para eucalipto: mês de fevereiro de 2010 (átomos $\%$ de ${ }^{15} \mathrm{~N}=0,42$ ) e junho de 2010 (átomos $\%$ de ${ }^{15} \mathrm{~N}=0,44$ ).

As análises dos teores de $\mathrm{N}$-total e átomos $\%$ de ${ }^{15} \mathrm{~N}$ foram realizadas com o auxílio de espectrômetro de massas, da marca ANCA-SL, no Laboratório de Isótopos Estáveis (CENA-USP).

\subsubsection{Delineamento experimental B}

O delineamento experimental B (Figura 7) possui parcelas mistas com $50 \%$ de $A$. mangium e 50\% de E. grandis (50A: 50E).

As bolsas de serapilheira confeccionadas com material vegetal marcado com ${ }^{15} \mathrm{~N}$ foram organizadas em quatro composições diferentes:

A*E: bolsas com folhas de acácia marcadas e folhas de eucalipto não marcadas;

A*A: bolsas com folhas de acácia marcadas e folhas de acácia não marcadas;

$\mathrm{E}^{*} \mathrm{~A}$ : bolsas com folhas de acácia não marcadas e folhas de eucalipto marcadas;

$\mathrm{E}^{*} \mathrm{E}$ : bolsas com folhas de eucalipto não marcadas e folhas de eucalipto marcadas.

No Experimento B, foram monitoradas 192 bolsas (4 tratamentos $\times 4$ repetições $\times 3$ parcelas $\times 4$ coletas). 
As bolsas foram dispostas em quatro direções em um mesmo exemplar arbóreo. Quatro árvores foram escolhidas por parcela: duas de eucalipto e duas de acácia (Figura 7), pois a disposição das bolsas foi alternada no eixo e na posição das folhas marcadas, colocadas tanto com a superfície para cima quanto para baixo.

50A: 50E

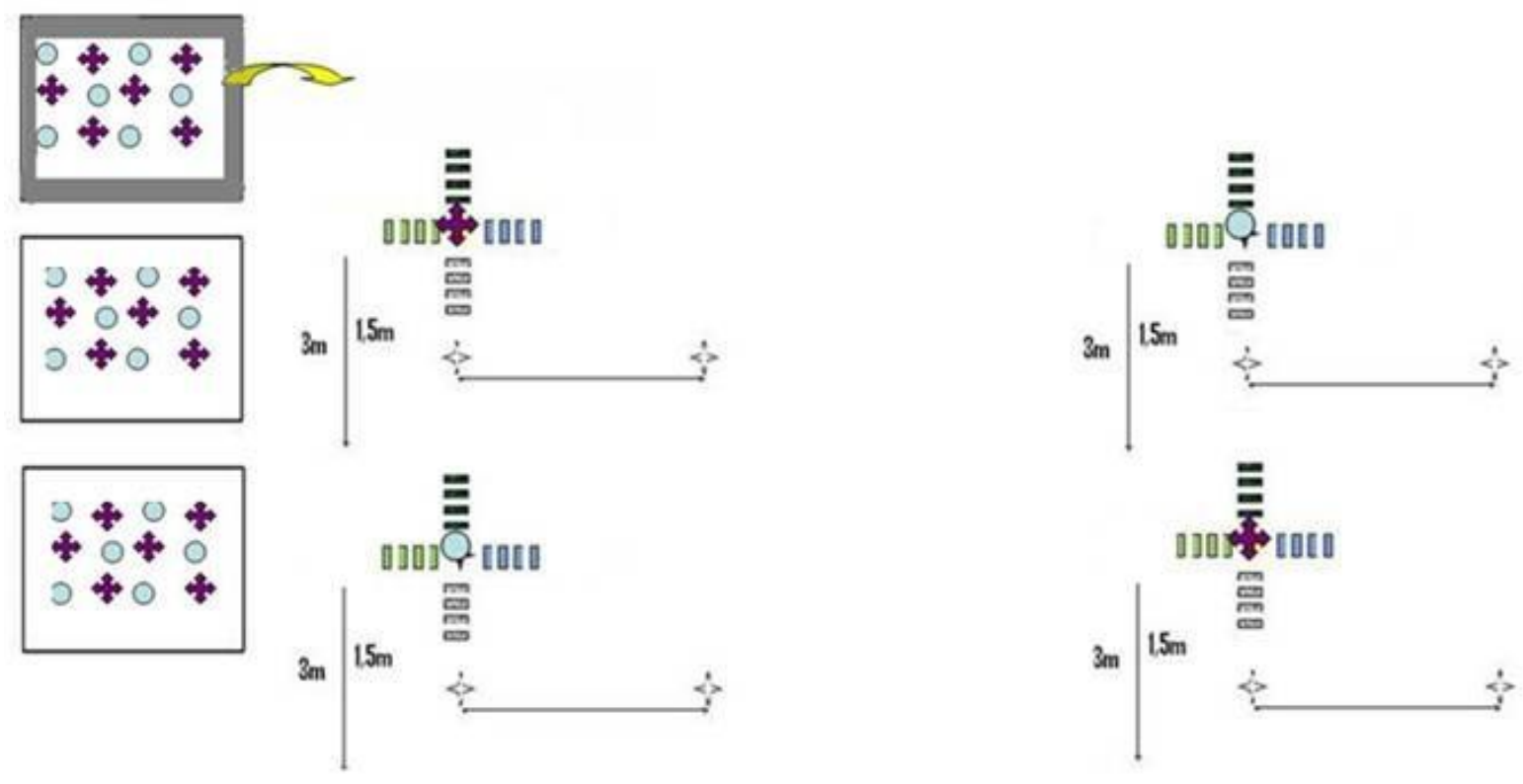

\footnotetext{
- Folhas de Acácia marcadas + folhas de Eucalipto não marcadas

$\square$ Folhas de Acácia marcadas + folhas de Acácia não marcadas

- Folhas de Eucalipto marcadas + folhas de Acácia não marcadas

Folhas de Eucalipto marcadas + folhas de Eucalipto não marcadas

Planta de Eucalipto

* Planta de Acácia

$\therefore$ Plantas não utilizadas para disposição das bolsas
}

Norte

Figura 7 - Disposição espacial das bolsas de serapilheira para cada parcela do Experimento B - Transferência bruta de N entre Eucalyptus e Acacia

\subsubsection{Instalação do experimento e coleta das bolsas de decomposição}

$\mathrm{O}$ experimento $\mathrm{B}$ de transferência de $\mathrm{N}$ foi instalado em dezembro de 2010, quando foram colocadas 64 bolsas em cada parcela: 16 com A*E, 16 com A*A, 16 com E*A e 16 com $\mathrm{E}^{*} \mathrm{E}$. 
a)

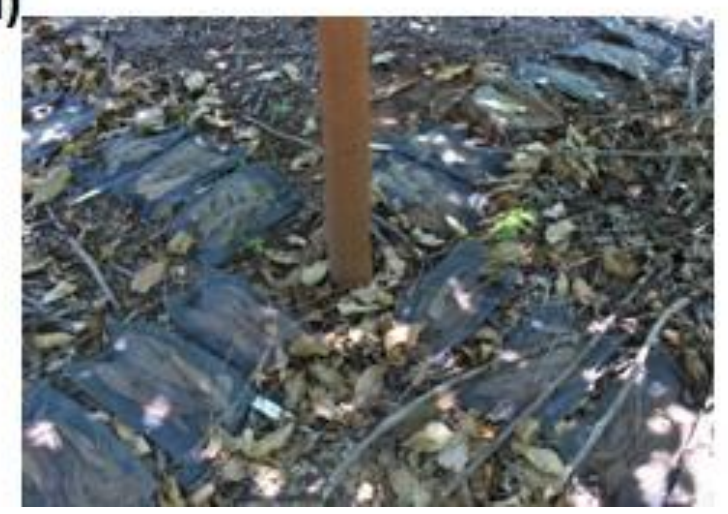

b)

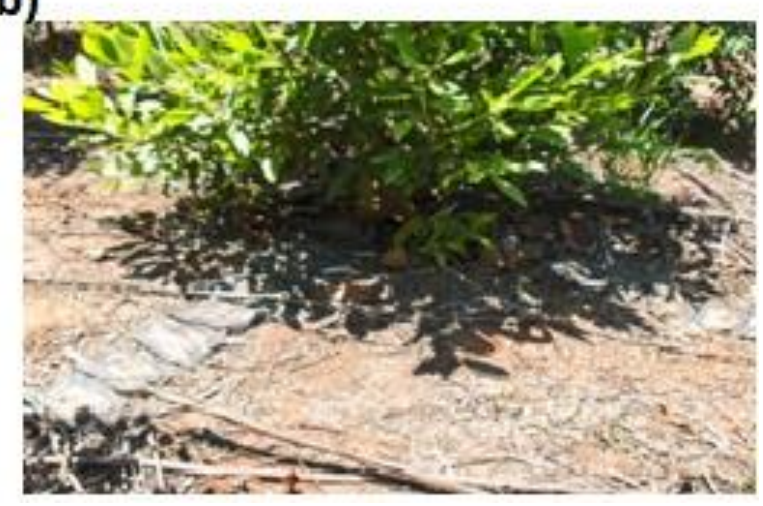

Figura 8 - Instalação do experimento B nas parcelas mistas, em dezembro de 2010, em a) bolsas dispostas na planta de E. grandis; b) bolsas dispostas na planta de $A$. mangium

As coletas das bolsas de decomposição do experimento de transferência foram realizadas após 3, 6, 9 e 12 meses da instalação (entre março e dezembro de 2011), o que correspondeu, respectivamente, a 90, 182, 274 e 364 dias de experimento. A cada coleta, foi retirada uma bolsa de cada composição por planta e por parcela. Cada parcela possui 4 quatro repetições de plantas, com 4 quatro composições diferentes de bolsas cada; portanto, as coletas tiveram $4 \times 4 \times 3$ bolsas de decomposição coletadas por data.

Após as coletas, o material no interior das bolsas foi retirado para determinação da perda de massa, correção da contaminação mineral do solo por determinação do teor de cinzas (Laboratório de Ecologia Aplicada, ESALQ/USP) e para as demais análises.

Os dois tipos de folhas diferentes que constituíram cada bolsa foram separados de acordo com a classificação: (1) folhas fonte de $\mathrm{N}$ : as folhas marcadas de ${ }^{15} \mathrm{~N}$, e (2) folhas dreno de $\mathrm{N}$ : as folhas não marcadas de ${ }^{15} \mathrm{~N}$.

Os tratamentos de folha fonte foram:

FA*A: folha de acácia marcada que esteve combinada com folha de acácia não marcada;

FA*E: folha de acácia marcada que esteve combinada com folha de eucalipto não marcada;

FE*A: folha de eucalipto marcada que esteve combinada com folha de acácia não marcada;

$\mathrm{FE}^{*} \mathrm{E}$ : folha de eucalipto marcada que esteve combinada com folha de eucalipto não marcada.

Os tratamentos de folhas dreno foram:

AFA*: folha de acácia não marcada que esteve combinada com folha de acácia marcada;

$\mathrm{AFE}^{*}$ : folha de acácia não marcada que esteve combinada com folha de eucalipto marcada;

EFA*: folha de eucalipto não marcada que esteve combinada com folha de acácia marcada;

EFE*: folha de eucalipto não marcada que esteve combinada com folha de eucalipto marcada. 


\subsubsection{Análise de $\mathrm{N}$-total e átomos $\%$ de ${ }^{15} \mathrm{~N}$ das folhas em transferência de $\mathrm{N}$}

As análises dos teores de $\mathrm{N}$-total e átomos $\%$ de ${ }^{15} \mathrm{~N}$ foram realizadas a partir de amostras compostas em duas combinações diferentes: (1) aos 3 e 9 meses, foram agrupadas por tipo de material (FEM, FAM, FE e FA) por parcela, e (2) aos 6 e 12 meses, a combinação de amostras também foi por tipo de material, mas separando as que foram retiradas do exemplar arbóreo de eucalipto das do exemplar arbóreo de acácia, por parcela.

As análises dos teores de $\mathrm{N}$-total e átomos $\%$ de ${ }^{15} \mathrm{~N}$ foram realizadas com o auxílio de espectrômetro de massas, da marca ANCA-SL, no Laboratório de Isótopos Estáveis (CENA-USP).

\subsubsection{Determinação da transferência bruta de $\mathrm{N}$ entre as folhas}

A porcentagem de $\mathrm{N}$ transferida $(\mathrm{Nt})$ das folhas marcadas para as folhas não marcadas foi calculada segundo modelo adaptado de Schimel e Hättenschwiller (2007), representado na equação (4):

$$
\mathrm{Nt}=\frac{\left({ }^{15} \mathrm{~N} \text { das folhas não marcadas }-{ }^{15} \mathrm{~N}\right. \text { inicial das folhas não marcadas) }}{{ }^{15} \mathrm{~N} \text { das folhas marcadas no início }}
$$

\subsubsection{Análises estatísticas dos dados}

Os dados da transferência de $\mathrm{N}$ entre as folhas em decomposição foram analisados a cada coleta separadamente e testados em relação à normalidade e à homogeneidade de variância por meio do teste de Shapiro-Wilk e do modelo de Box-Cox, respectivamente.

Os resultados da taxa de transferência foram comparados em relação aos tratamentos drenos (FAFAM, FAFEM, FEFAM e FEFEM), utilizando-se um modelo linear pelo comando PROC GLM. A transformação dos resultados deu-se pela função "Asen (raiz quadrada)" e a diferença entre os tratamentos foi avaliada pelo teste de média Tukey com nível de significância de 0,05. Todos os testes foram realizados empregando-se o pacote estatístico SAS 9.1 (SAS Institute). 


\section{RESULTADOS E DISCUSSÃO}

\subsection{Experimento A}

\subsubsection{Perda de massa de folhas e raízes durante a decomposição}

As folhas de acácia (FA) e as folhas e eucalipto (FE) apresentaram valores de porcentagens de massas remanescentes distintos, durante todo o período (Figura 9). Diferenças significativas foram observadas entre a decomposição das folhas durante os três primeiros meses, quando as folhas de eucalipto apresentaram maior perda de massa do que as de acácia, com porcentagens médias de massa remanescente de $73 \%$ e $90 \%$ para FE e FA, respectivamente. Ao final do período estudado, foram observados padrões de decomposição para as folhas, sendo que FA e FE apresentaram porcentagens de massa remanescente em torno de $76 \%$ e 60\%, em média, respectivamente. Aos 367 dias, assim como para todo o período de estudo, não houve diferenças entre os tratamentos de FA (FAE, FA1R e FA2R) e entre os tratamentos de FE (FEE, FE1R e FE2R); entretanto, FE2R foi diferente dos tratamentos de FA.

$\mathrm{Na}$ primeira fase do experimento, que perfez 92 dias, a perda de massa foi, em média, de $68 \%$ para os tratamentos de raízes e sem diferença entre estes (Figura 10). No final do período, não houve diferença entre os tratamentos de RA e entre os tratamentos de RE; entretanto, RAE e RE1R foram diferentes.

Estes resultados de decomposição de folhas também são observados em outros estudos que fazem referência a uma maior perda de massa no início, tanto das folhas de eucalipto quanto das folhas de acácia. O início do experimento correspondeu ao começo da estação de elevadas temperaturas e pluviosidade, o que incrementou a decomposição inicial. Orsborne e Macauley (1988) observaram correlação positiva entre a perda de massa de Eucalyptus com umidade e temperatura. A fase de expressiva perda de massa normalmente corresponde à decomposição dos componentes mais lábeis e à lixiviação de materiais solúveis para folhas (CASTELLANOS-BARLIZA; PELÁEZ, 2011) e para raízes (MELLO; GONÇALVES; GAVA, 2007). As maiores perdas foram em FE que, embora apresentasse maior relação $\mathrm{C} / \mathrm{N}$ que FA, possui maiores concentrações de $\mathrm{C}$ solúvel (HERNÁNDEZ et al., 2009). Xiang e Bauhus (2007), em trabalho sobre decomposição em plantio consorciado de Acacia mearnssi e Eucalyptus globulus, não consideram o material do eucalipto recalcitrante, apesar da alta relação C/N (BRIONES; INESON, 1996). Esses autores também observaram 
grande valor de perda de massa (75\% de massa remanescente) durante a primeira fase de decomposição, considerando-a por um tempo de 110 dias de incubação do material em laboratório. Entretanto, esses autores encontraram aumento na decomposição do eucalipto no consórcio, que não foi em razão do aumento da quantidade de $\mathrm{N}$ e $\mathrm{P}$, mas sim dos fatores adicionais, como compostos secundários ou a estrutura de determinados compostos.

A fase inicial, com perda de massa muito elevada em raízes, esteve relacionada com a grande concentração inicial de extratos solúveis. Após este período, Mello, Gonçalves e Gava (2007) observaram que a decomposição das raízes foi mais lenta em função da imobilização de nutrientes pelos microrganismos, além da ação de frações recalcitrantes que podem inibir o processo. Esses autores também encontraram oscilações nas porcentagens de massa remanescente de raízes, no período estudado.

A decomposição das raízes de eucalipto foi comparada com a de outras espécies (Cupressus lusitanica, Pinus patula e espécies nativas da Etiópia) por Lemma et al. (2007). No trabalho desses autores, encontraram lenta perda de massa para raízes de eucalipto, pois este material apresenta compostos dificilmente decomponíveis. No presente trabalho, a presença de características menos recalcitrantes, como maior concentração de $\mathrm{N}$ e menor relação $\mathrm{C} / \mathrm{N}$ para as raízes de acácia no solo de eucalipto, pode ter incrementado a ação dos decompositores no material da acácia, que apresentou considerável perda de massa neste local.

O uso da técnica de litterbags para decomposição de raízes é questionável, pois ocasiona algumas limitações na colonização dos decompositores, podendo subestimar a perda de massa e aumentar a variação de massa remanescente ao longo do tempo de estudo (DORNBUSH; ISENHART; RAICH, 2002). Supõe-se que, em situação natural, poderia haver retranslocação de nutrientes das raízes em decomposição para as novas (MELLO; GONÇALVES; GAVA, 2007).

As folhas e raízes no mesmo tipo de material não tiveram o mesmo padrão de decaimento, ao contrário do observado na literatura por Wang, Liu e Mo (2010). Nesse estudo sobre decomposição de folhas e raízes finas em quatro espécies subtropicais (P. massoniana, C. hytrix, M. macclurei e M. laosenisis), na China, houve correlação entre o decaimento do material acima do solo e aquele abaixo do solo. A correlação encontrada foi devida às condições semelhantes de umidade do solo e também na composição química dos materiais (WANG; LIU; MO, 2010). No presente trabalho, as folhas e raízes, para eucalipto e acácia, diferiram na composição química inicial, o que pode ter ocasionado divergência no padrão de perda de massa entre folhas e raízes. 


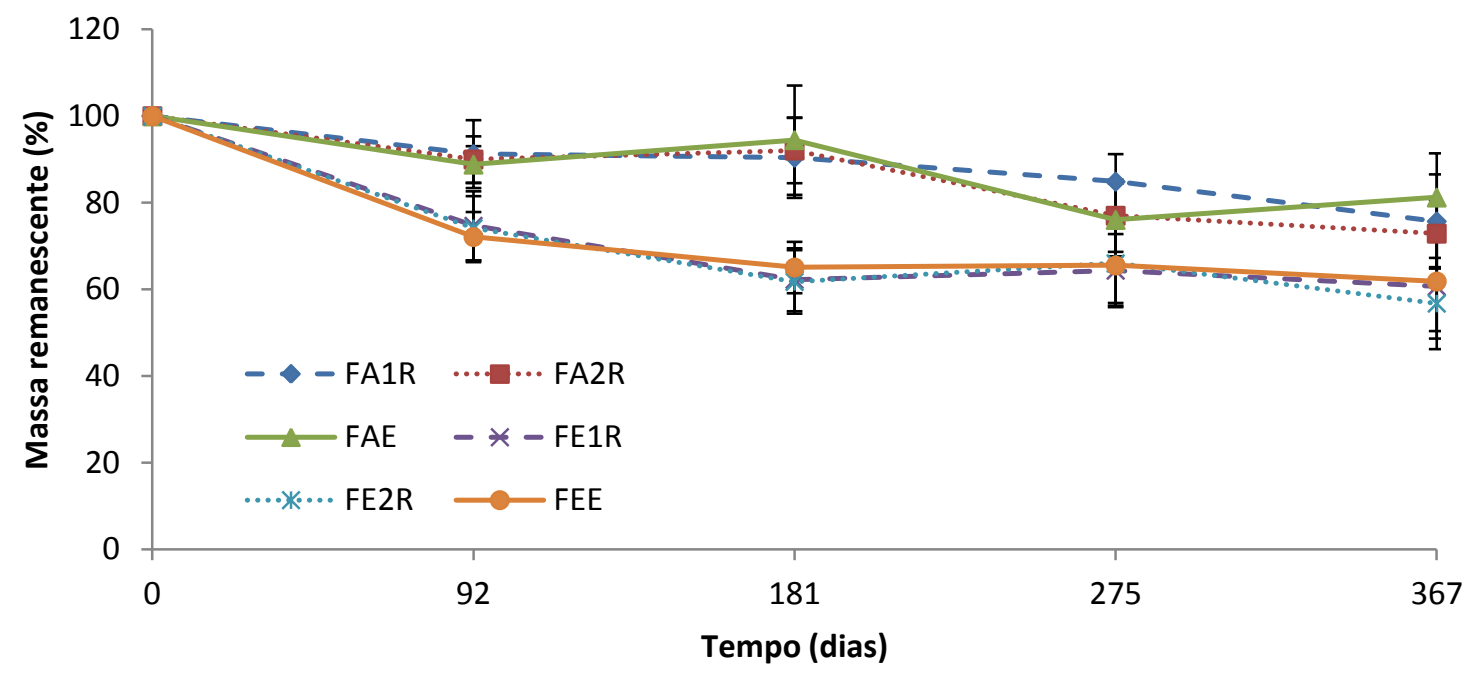

Figura 9 - Decaimento de massa das folhas de E. grandis e A. mangium durante 367 dias de decomposição, nos tratamentos FAE, FA1R, FA2R, FEE, FE1R e FE2R. Os valores representam a média $(n=9) \pm$ desvio padrão

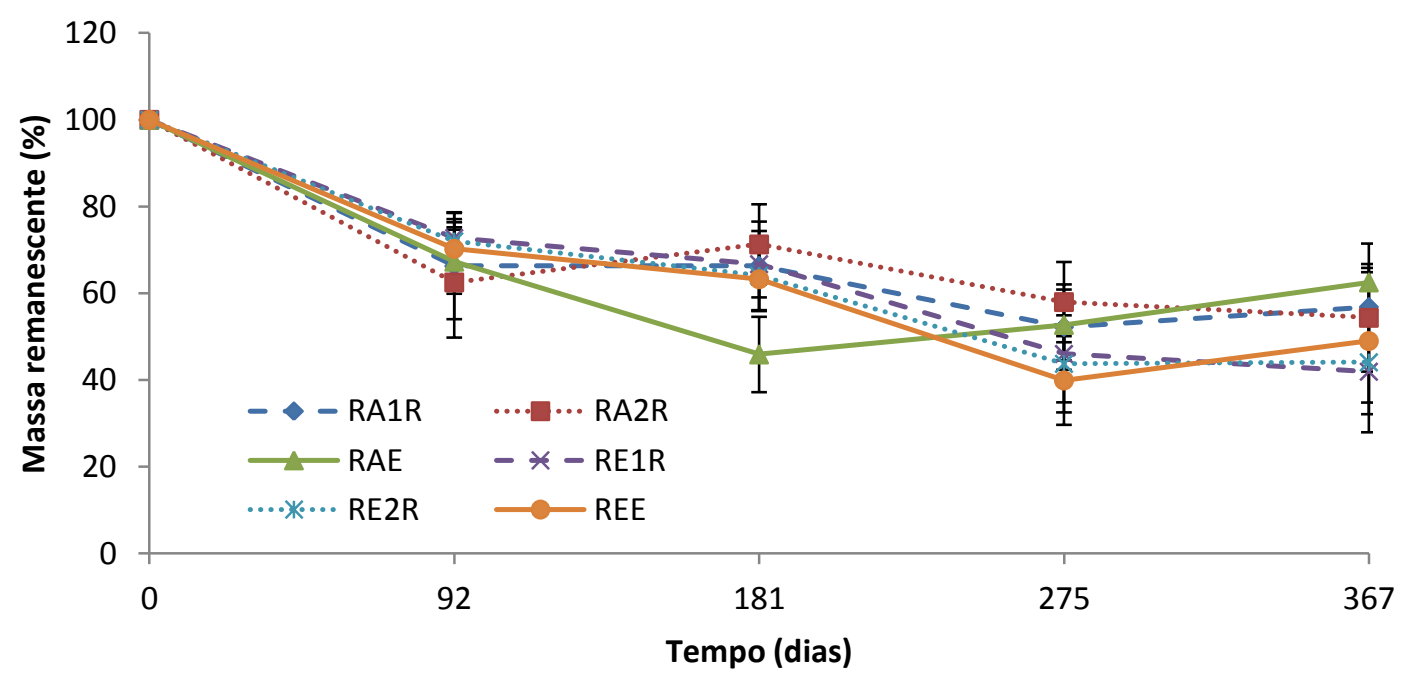

Figura 10 - Decaimento de massa das raízes de E. grandis e A. mangium durante 367 dias de decomposição, nos tratamentos RAE, RA1R, RA2R, REE, RE1R e RE2R. Os valores representam a média $(n=9) \pm$ desvio padrão

A teoria da vantagem doméstica em curto prazo não foi observada, uma vez que a decomposição foi influenciada apenas pela composição química do material (AYRES et al., 2009; JOHN; ORWIN; DICKIE, 2011). O material da acácia, mesmo em segunda rotação, pode não influenciar no desenvolvimento da microbiota mais especializada para decompor melhor o seu próprio resíduo. Em trabalho de Ayres, Dromph e Bardgett (2006), os resíduos de serapilheira foram incubados com microrganismos do solo original e não foram 
observados efeitos dos microrganismos na decomposição, pelo menos durante a fase inicial da decomposição.

$\mathrm{Na}$ literatura, a HFA apresenta resultados diversos, como o trabalho de Ayres et al. (2009), em que não foi encontrada HFA em todos os tipos de material em decomposição, sendo que os resultados encontrados em laboratório não foram os mesmos em condições de campo. Esses autores sugerem que as diferentes comunidades microbianas no solo não são funcionalmente equivalentes; por isso, pode-se observar a presença de HFA. Entretanto, a relação entre HFA e o tempo é complexa, em razão da capacidade de colonização de cada comunidade de decompositores e também da mudança na estrutura química que o material em decomposição passa durante o processo, provocando alterações nos microrganismos (AYRES et al., 2009). Em trabalho de Barantal et al. (2011) sobre a decomposição de diferentes misturas de serapilheira na Guiana Francesa, também foi encontrado efeito do local na decomposição. A serapilheira teve maior perda de massa no local de origem do que em outros locais, apesar de as condições climáticas serem iguais. Esses autores sugerem que o dossel pode exercer influência na comunidade microbiana do solo em longo prazo. Portanto, o tempo de presença de A. mangium no local, mesmo que em segunda rotação, pode ainda ser insuficiente para influenciar na decomposição da sua própria serapilheira.

\subsubsection{Composição de compostos orgânicos das folhas e raízes em decomposição}

A composição dos compostos orgânicos do material vegetal (folhas e raízes) em decomposição (lignina, celulose, hemicelulose, carboidratos solúveis, fenóis totais, taninos totais e taninos condensados) foi analisada no início, tempo zero (Anexo C), e ao final do período, que perfez 367 dias (Anexos D e E).

\section{- Lignina, celulose, hemicelulose e carboidratos solúveis das folhas e raízes em decomposição}

As folhas de acácia apresentaram maiores valores de lignina em comparação às folhas de eucalipto, no início e após 12 meses de experimento (Figura 11). Após 367 dias, a lignina nas folhas foi o único composto orgânico que não teve os valores de teores alterados $(p>0,2)$. A porcentagem de quantidade de lignina remanescente após um ano de estudo foi maior em FA que em FE, com $73 \%$ e $60 \%$, respectivamente ( $p>0,003)$. Nas raízes, não foi observada diferença nos valores das concentrações de lignina entre RA e RE, no início e no final do 
período, em que a quantidade remanescente de lignina em relação ao início foi $45 \%$ em RA e $30 \%$ em RE $(p>0,006)$.
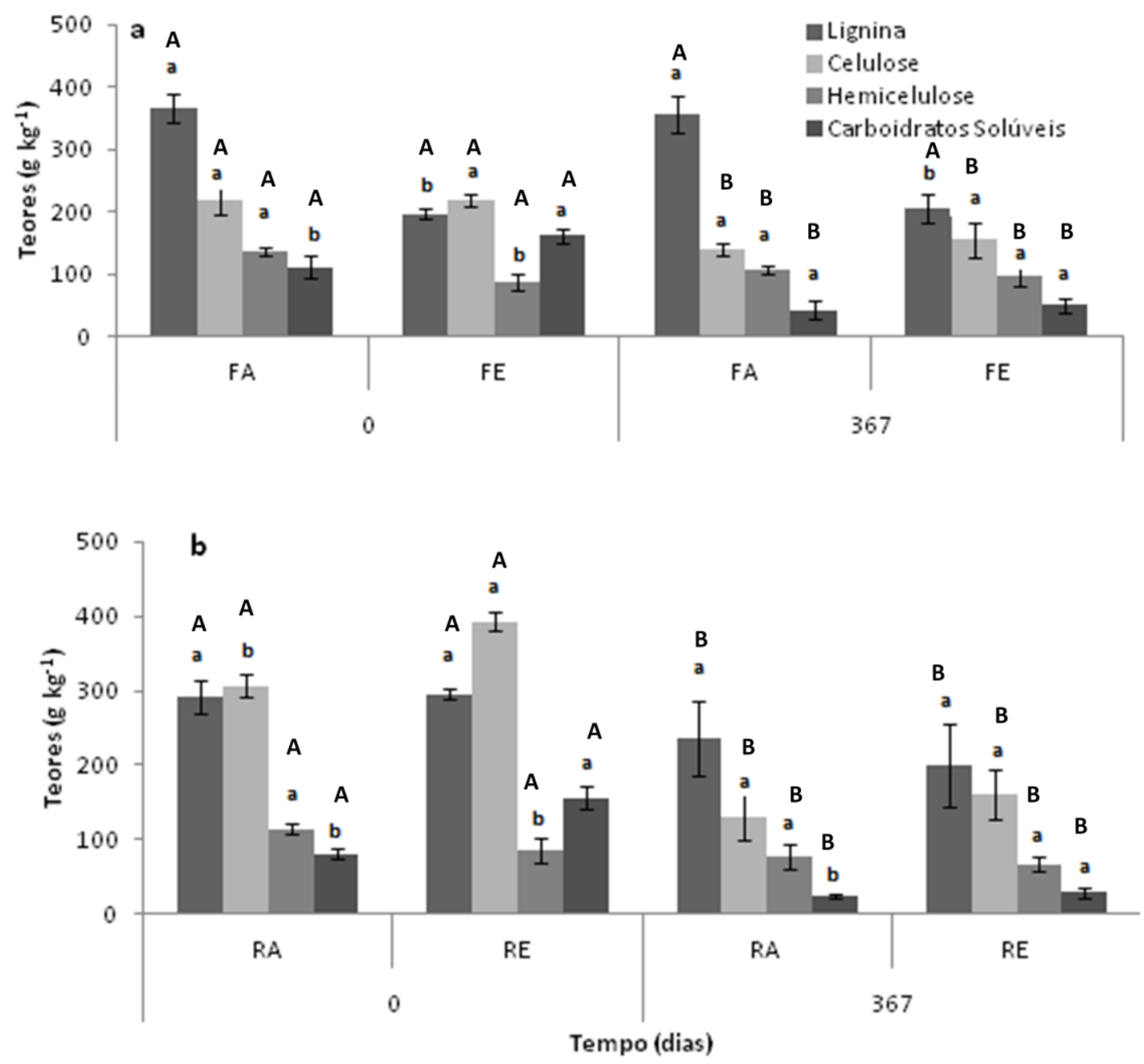

Figura 11 - Teores de lignina, celulose, hemicelulose e carboidratos solúveis nas folhas (a) e raízes (b) de Eucalyptus grandis e Acacia mangium durante o experimento de decomposição: a) folhas nos tratamentos FAE, FA1R, FA2R, FEE, FE1R e FE2R; b) raízes nos tratamentos RAE, RA1R, RA2R, REE, RE1R e RE2R. Os valores representam a média $(n=9) \pm$ desvio padrão. As diferenças significativas entre tratamentos em cada data são indicadas por letras minúsculas diferentes $(p<0,05)$. As diferenças significativas entre as datas em cada tratamento são indicadas por letras maiúsculas diferentes $(p<0,05)$

Os valores iniciais de lignina encontrados nas folhas no material do estudo de decomposição correspondem aos valores na literatura para acácia (HARQUINDEGUY et al., 2008, DJARWANTO; TACHIBANA, 2010) e para eucalipto (COSTA; GAMA-RODRIGAS; 
CUNHA, 2005). Costa, Gama-Rodrigas e Cunhas (2005) encontraram aumento na concentração de lignina durante os 286 dias de decomposição e início da liberação, aos 382 dias. O aumento na concentração deste composto é provavelmente em função da perda de massa do material (BERG; EKBOHM; MCCLAUGHERTY, 1984). A lignina se apresentou como o composto que retardou a decomposição das folhas. Entretanto, a forma de atuação da lignina pode ser diferente entre FA e FE, pois as quantidades remanescentes diferem entre os tipos de folhas. Em FE, houve maior disponibilidade de C facilmente degradável, como carboidratos solúveis, que são utilizados primeiramente pelos microganimos (BAUMANN et al., 2011). A alta concentração de lignina pode ter sido responsável pela menor perda de massa em FA, pois é encontrada, na literatura, correlação negativa entre a concentração de lignina e a decomposição (HÄTTENSCHWILER; JORGENSENT, 2010; BARANTAL et al., 2011). Nas raízes, a menor quantidade remanescente de lignina em RE pode ser resultado da atuação da comunidade decompositora especializada na degradação do material de eucalipto, após sucessivos anos de rotações da espécie na área estudada. Talbolt e Treseder (2012) suportam a hipótese de que a lignina protege os polissacarídeos das paredes celulares de degradação microbiana. A lignina não apresenta sempre o mesmo desempenho à decomposição, assim como o encontrado por Talbolt et al. (2011) sobre os diferentes níveis de recalcitrância da lignina, de acordo com as variações estruturais que essa molécula apresenta. Assim, a diferente conduta deste componente entre folhas e raízes pode ser devida aos distintos tipos de lignina entre esses compostos.

A concentração inicial de celulose não foi diferente entre os tipos de folhas utilizadas e, após 367 dias, a porcentagem de quantidade de celulose remanescente foi de $48 \%$ e $41 \%$ em FA e FE, respectivamente $(p>0,0784)$. A quantidade de celulose para as raízes, ao final do período, demonstrou distinção entre os tipos de raízes, permanecendo $24 \%$ em RA e $18 \%$ em RE ( $p>0,0127)$. Costa, Gama-Rodrigas e Cunha (2005) também encontraram diminuição nos valores de celulose para folhas de eucalipto da ordem de $50 \%$, em relação à concentração inicial, após período semelhante de decomposição. Esses autores ainda observaram relação entre a perda de celulose e altas taxas pluviométricas. A ausência de diferença na decomposição da celulose, apesar de folhas com diferentes concentrações iniciais de $\mathrm{N}$, sugere que a degradação deste composto não foi influenciada pela quantidade deste elemento. Entretanto, Talbolt e Treseder (2012), ao isolarem o efeito de celulose na decomposição, encontraram correlação positiva entre a perda de celulose e a concentração inicial de $\mathrm{N}$ do material vegetal. Esses autores observaram que a celulose não foi o componente que exerceu o maior controle na decomposição, mas pode ser usado como fonte de C para os 
microrganismos durante o processo, o que incrementa a degradação da lignina (TALBOLT; TRESEDER, 2012).

As folhas de acácia apresentaram maior concentração inicial de hemicelulose em comparação às de eucalipto. Este é outro composto que apresenta controle na decomposição, pois foi encontrada, na literatura, correlação negativa entre a concentração inicial de hemicelulose e a perda de massa da serapilheira (VIVANCO; AUSTIN, 2008; BARANTAL et al., 2011). As concentrações de hemicelulose iniciais nas raízes também foram maiores para o material da acácia. Ao final do período, não houve diferença na concentração de hemicelulose entre os tipos de folhas e entre os tipos de raízes.

O material de eucalipto, folhas e raízes, apresentou os maiores teores iniciais de carboidratos solúveis. Este componente se apresentou como o responsável pela maior perda de massa do material durante os três meses iniciais de estudo e pela perda mais acentuada em FE. Relações positivas, durante a fase inicial da decomposição de serapilheira, com a concentração de carboidratos solúveis são encontradas diversas vezes na literatura (BERG, 1986; VIVANCO; AUSTIN, 2008; PÉREZ-SUÁREZ; ARREDONDO-MORENO; HUBERSANNWALD, 2012).

\section{- Taninos totais, taninos condensados e outros fenóis nas folhas e raízes em decomposição}

No início deste estudo, FA apresentou os maiores valores para taninos condensados e outros fenóis, enquanto FE teve os maiores valores apenas para taninos totais (Figura 12). Nas raízes, as de eucalipto mostraram os mais altos valores iniciais para taninos totais, taninos condensados e outros fenóis. Entretanto, após 367 dias de decomposição, as concentrações destes compostos em folhas e raízes não apresentaram diferenças entre os tipos de material, exceto para taninos condensados, cujo valor, em FA, continuou maior que em FE.

$\mathrm{Na}$ literatura, é encontrado que os fenóis do eucalipto são responsáveis pela recalcitrância deste material (CANHOTO; GRAÇA, 1996); entretanto, no presente trabalho, as folhas de eucalipto não apresentaram esta característica em comparação às da acácia. Os fenóis correspondem a uma ampla classe de compostos, com diferentes maneiras de atuar na decomposição: efeitos na comunidade e atividade microbiana, incluindo incremento na decomposição e efeitos físico-químicos (HÄTTENSCHWILER; VITOUSEK, 2000). Efeitos positivos de fenóis na decomposição foram encontrados em alguns trabalhos (VIVANDO; AUSTIN, 2008, HÄTTENSCHWILER; JORGENSENT, 2010). Os efeitos 
positivos podem ser devidos a fenóis solúveis, que lixiviam no início da decomposição (HÄTTENSCHWILER; VITOUSEK, 2000). Esse fato pode ter incrementando a decomposição de FE, que apresenta maior concentração inicial destes compostos.
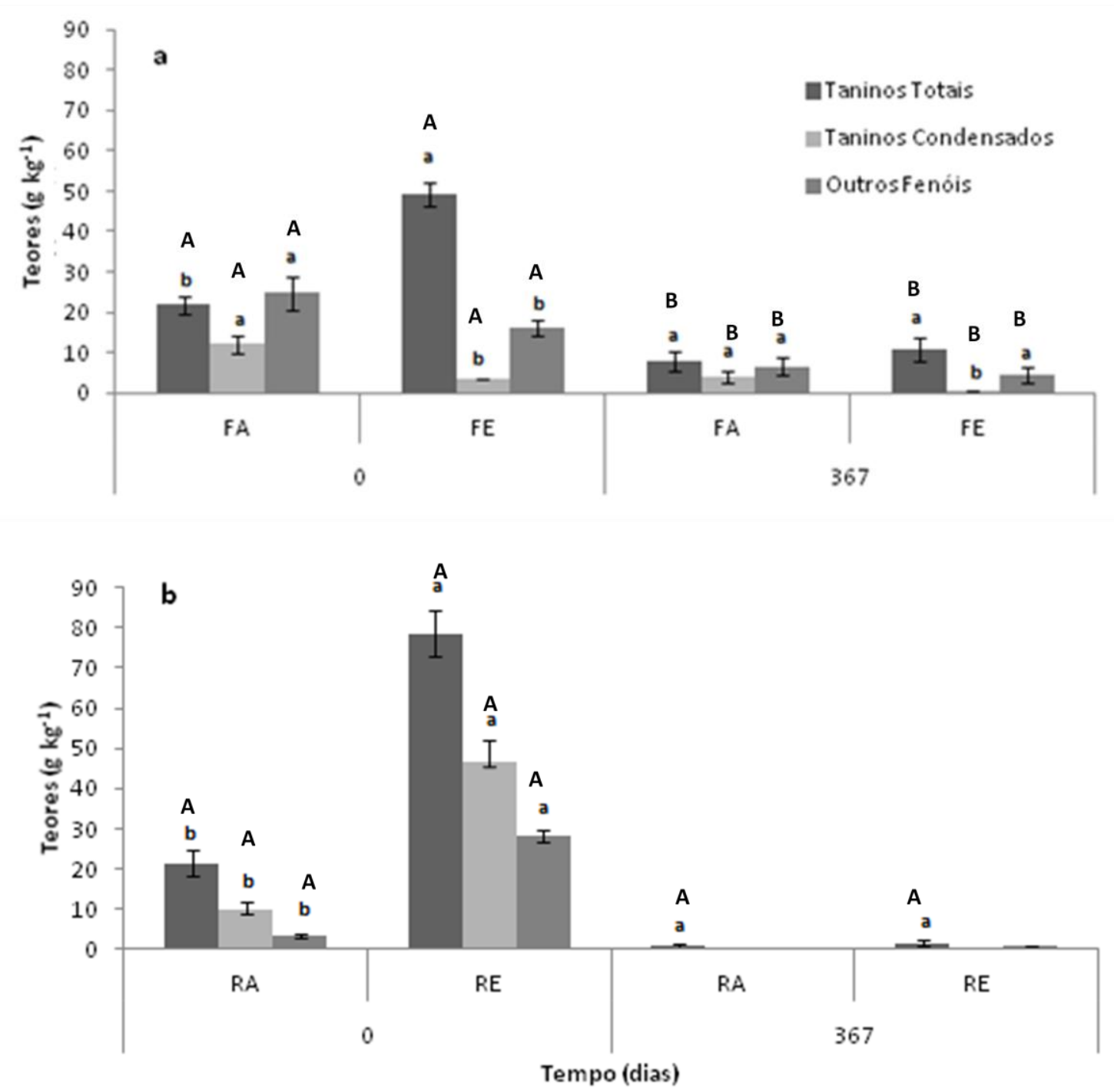

Figura 12 - Teores de taninos totais, taninos condensados e outros fenóis nas folhas (a) e raízes (b) de Eucalyptus grandis e Acacia mangium durante o experimento de decomposição: a) folhas nos tratamentos FAE, FA1R, FA2R, FEE, FE1R e FE2R; b) raízes nos tratamentos RAE, RA1R, RA2R, REE, RE1R e RE2R. Os valores representam a média $(n=9) \pm$ desvio padrão. As diferenças significativas entre tratamentos em cada data são indicadas por letras minúsculas diferentes $(p<0,05)$. As diferenças significativas entre as datas em cada tratamento são indicadas por letras maiúsculas diferentes $(p<0,05)$

Os altos valores iniciais de taninos condensados encontrados em FA podem ser correlacionados negativamente com a perda de massa da serapilheira, assim como é encontrado na literatura (HÄTTENSCHWILER; JORGENSENT, 2010; BARANTAL et al., 
2011). A influência negativa na decomposição por estes compostos é em virtude da facilidade de estes formarem complexos com proteínas, o que torna o $\mathrm{N}$ indisponível aos microrganismos. Os complexos protegem outros compostos, como a celulose, da decomposição e são resistentes à ação de quase todos decompositores, exceto alguns basidiomicetos, que possuem polifenol oxidase (HÄTTENSCHWILER; VITOUSEK, 2000). Para as raízes, embora a concentração maior de taninos, totais e condensados, em RE classifique este material como recalcitrante, após 12 meses de decomposição, não houve concentrações significativas desses compostos nas raízes.

\subsubsection{Dinâmica de carbono, nitrogênio, enxofre, fósforo e potássio em folhas e raízes}

Os teores e quantidades de carbono, nitrogênio, enxofre, fósforo e potássio totais para as folhas e raízes de E. grandis e A. mangium foram analisados no início (Anexos F e G) e durante todas as coletas (Anexos H, I, J e K).

\section{- Teor e quantidade de carbono}

A concentração inicial de $\mathrm{C}$ foi maior em FE e assim permaneceu durante os três primeiros meses, quando os tratamentos não apresentaram mudanças significativas nos teores de C (Figura 13). Entretanto, as quantidades de C diminuíram em todos os tratamentos cerca de 50\%, com os menores valores para FEE e FE2R. Após seis meses, os tratamentos das folhas iniciaram inclinação de perdas gradativas de $\mathrm{C}$, sem diferença entre os valores de teores, mas com distinção dos valores de quantidade, maiores para FA e menores para FE. Após nove meses, o FEE apresentou o menor valor de quantidade e o FA1R, o maior valor. No último período observado, as folhas de eucalipto estabilizaram a perda de massa; entretanto, em FAE, continuaram a ocorrer perdas de $\mathrm{C}$, sendo o tratamento de folhas de acácia o que apresentou o menor de teor de $\mathrm{C}$.

As quantidades e os teores de $\mathrm{C}$ total para as raízes não apresentaram diferenças no início do estudo (Figura 14). No início do período, até os 181 dias, ocorreu diminuição nos valores de quantidade de $\mathrm{C}$ total, restando, em média, $60 \%$ da quantidade de $\mathrm{C}$ total em relação ao início. Ao final do período, não foi observada diferença entre os valores de quantidade de $\mathrm{C}$ total entre os tratamentos de cada tipo de folha. Os teores de $\mathrm{C}$ total para 
raízes também apresentaram tendência de perdas a partir da fase secundária, assim como para folhas.
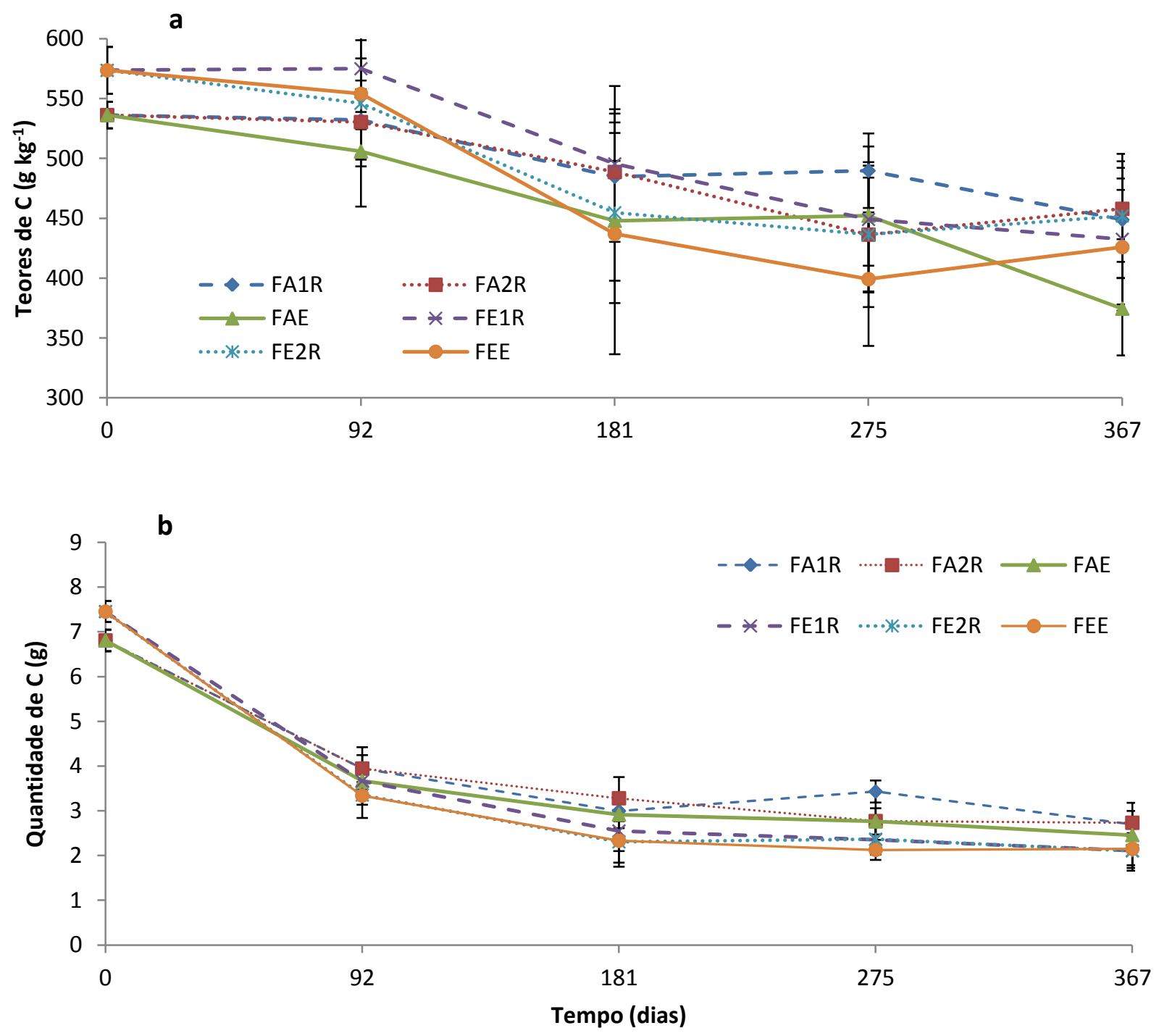

Figura 13 - Teores (a) e quantidades (b) de carbono nas folhas de E. grandis e A. mangium durante o experimento de decomposição nos tratamentos FAE, FA1R, FA2R, FEE, FE1R e FE2R. Os valores representam a média $(n=9) \pm$ desvio padrão

Em nenhum momento, os teores de $\mathrm{C}$ foram diferentes entres os tratamentos para cada tipo de raiz (RA ou RE). Assim como o observado para folhas, os teores e as quantidades de C não se conduzem da mesma forma. As raízes apresentaram inclinações para maiores perdas relativas na quantidade de $\mathrm{C}$ do que as folhas, restando, no final do período estudado, apenas $40 \%$ da quantidade de $\mathrm{C}$ inicial. 

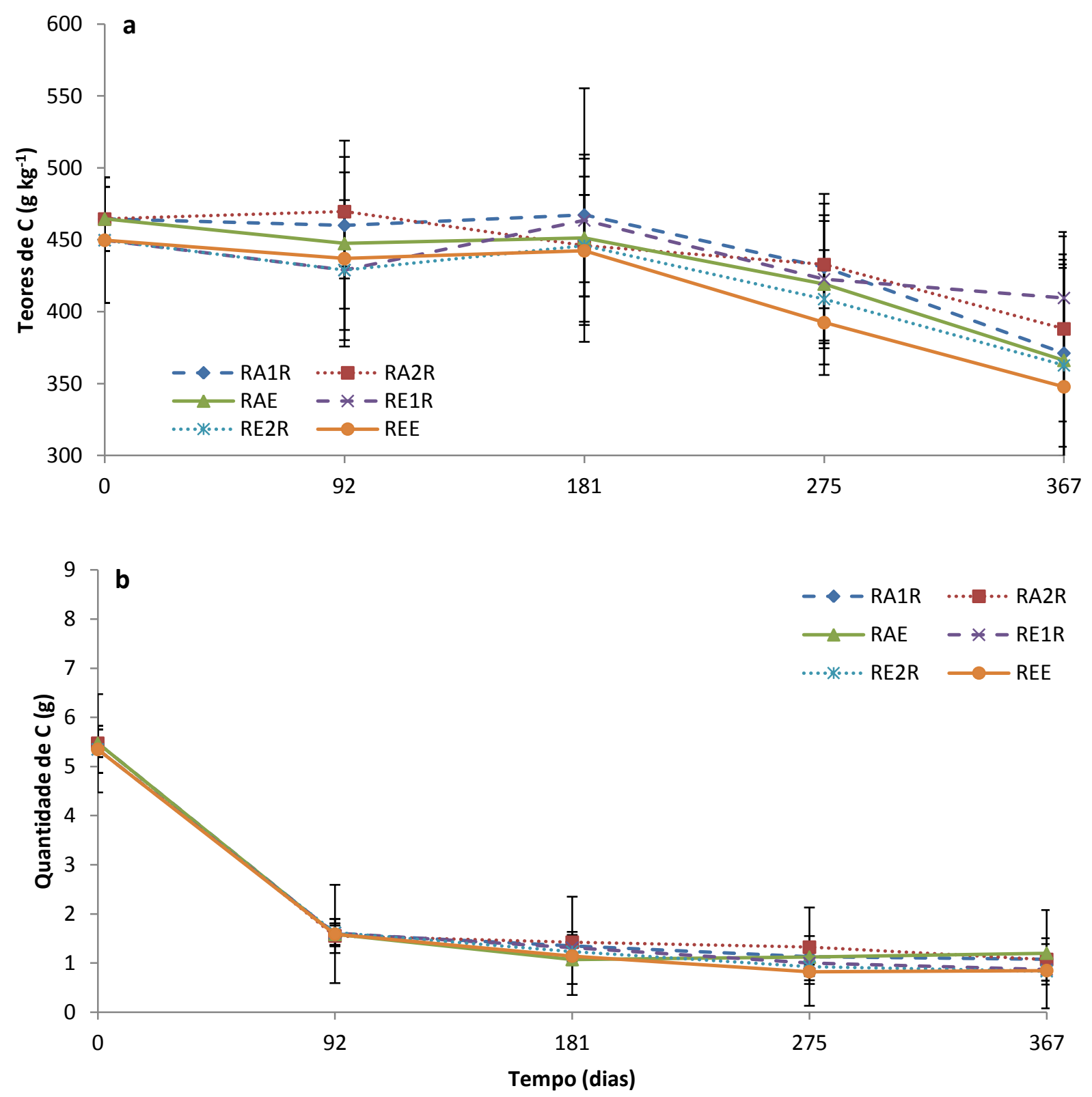

Figura 14 - Teores (a) e quantidades (b) de carbono nas raízes de E. grandis e A. mangium durante o experimento de decomposição nos tratamentos RAE, RA1R, RA2R, REE, RE1R e RE2R. Os valores representam a média $(n=9) \pm$ desvio padrão

As variações dos teores de $\mathrm{C}$ total em $\mathrm{FE}$ encontradas neste trabalho também foram relatadas na literatura, em que se aponta o início das alterações nos valores de teores de C ocorre apenas na fase secundária da decomposição (PÉREZ-SUÁREZ; ARREDONDOMORENO; HUBER-SANNWALD, 2012). As maiores perdas relativas de C para FE representam a mineralização de $\mathrm{C}$ e são positivamente correlacionadas à maior concentração de compostos solúveis em água e facilmente degradados, presentes neste tipo de material (HERNÁNDEZ et al., 2009); além disso, ocorreram, nas folhas deste material, 
componentes com maior quantidade de C solúveis, como os carboidratos. As perdas de $\mathrm{C}$ para FA podem estar relacionadas à degradação da porção lábil dos fenóis solúveis, quando os compostos mais facilmente degradáveis não estão mais presentes (NGAO; BERNAHARD-REVERSAT; LOUMETO, 2009). Nas perdas de C em raízes durante a primeira fase da decomposição, pode haver relação entre a decomposição apenas com a concentração dos compostos de C solúveis (BAUMANN et al., 2011).

\section{- Teor e quantidade de nitrogênio}

Os teores e a quantidade de $\mathrm{N}$ para folhas (Figura 14) mantiveram diferença entre FE e FA durante todo o estudo. Os valores de teores apresentaram tendência de aumento durante o período estudado, variando, em média, no início, entre 15 e $8 \mathrm{~g} \mathrm{~kg}^{-1}$, e após 367 dias, entre 19 e $13 \mathrm{~g} \mathrm{~kg}^{-1}$, para FA e FE, respectivamente. As folhas de eucalipto tiveram tendência linear para os teores de N, com aumento de $18 \%$ nos primeiros 92 dias e 35\%, em 182 dias. Ao contrário dos teores, as quantidades de $\mathrm{N}$ apresentaram perda nos três meses iniciais, $35 \%$ e $44 \%$ para FA e FE, respectivamente. Posteriormente, ao longo do estudo, manteve-se um padrão estável entre as quantidades de $\mathrm{N}$ para as folhas.

Os teores de $\mathrm{N}$ nas raízes (Figura 16) foram distintos entre RA e RE durante todo o período de estudo; entretanto, não houve diferença entre os tratamentos em nenhum momento. Os valores de teores para RE apresentaram orientação de aumento durante o período, variando, em média, no início, de $7 \mathrm{~g} \mathrm{~kg}^{-1}$, e após 367 dias, de $13 \mathrm{~g} \mathrm{~kg}^{-1}$. As quantidades de $\mathrm{N}$ para raízes tiveram tendência de diminuição aos 92 dias, observando-se $73 \%$ e $61 \%$ do valor inicial, para RA e RE, respectivamente. Assim como nas folhas, as quantidades de N após a perda inicial mantiveram médias constantes e, ao final do período de estudo, RA e RE foram diferentes entre si, mas não entre os tratamentos. $\mathrm{O}$ aumento da concentração de $\mathrm{N}$ pode ser relacionado à perda de massa do material. Esse aumento pode ser devido à imobilização inicial de $\mathrm{N}$ em FE, com maior acúmulo de $\mathrm{N}$ no período de chuvas pela lixiviação de compostos solúveis. $\mathrm{O}$ aumento nos valores das concentrações de $\mathrm{N}$ em folhas de Eucalyptus dunnii foi encontrado por Hernández et al. (2009) durante os três primeiros meses de decomposição, mas depois esses valores permaneceram estáveis em até dois anos de estudo. Também foi observado o aumento das concentrações de nitrogênio durante a decomposição de FA em relatos na literatura (CASTELLANOS-BARLIZA; PELÁEZ, 2011, PÉREZSUÁREZ; ARREDONDO-MORENO; HUBER-SANNWALD, 2012) e também em estudos 
com outras leguminosas (CORBEELS et al., 2003). As concentrações de $\mathrm{N}$ podem não exercer influência na decomposição em razão da formação de complexos tanino-proteínas, que protegem o $\mathrm{N}$ dos decompositores (NGAO; BERNHARD-REVERSAT; LOUMETO, 2009).
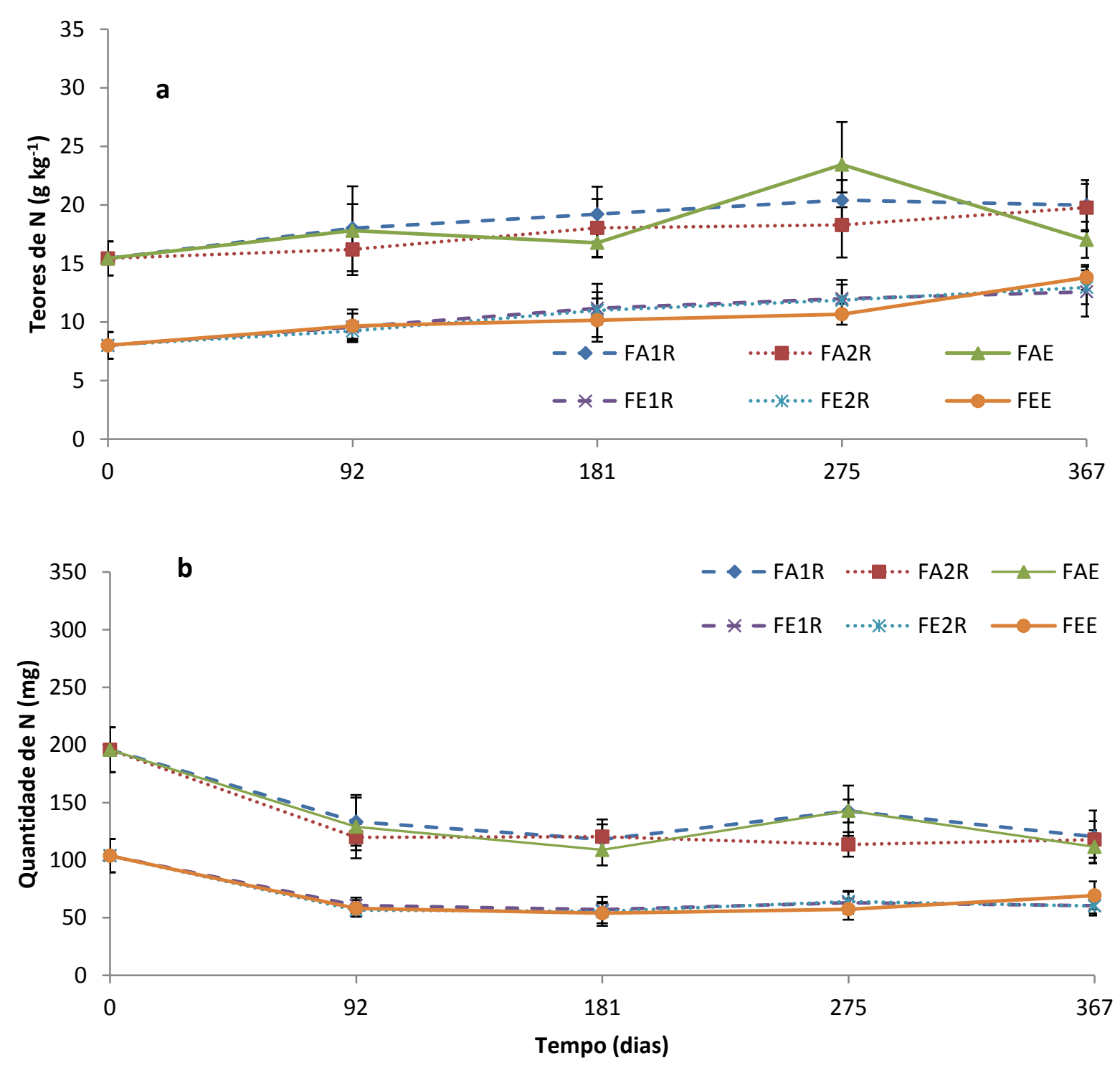

Figura 15 - Teores (a) e quantidades (b) de nitrogênio nas folhas de E. grandis e A. mangium durante o experimento de decomposição nos FAE, FA1R, FA2R, FEE, FE1R e FE2R. Os valores representam a média $(n=9) \pm$ desvio padrão

No presente estudo, houve perda nas quantidades de $\mathrm{N}$ em todos os tipos de folhas e tratamentos. As perdas de $\mathrm{N}$ ocorrem por meio da lixiviação na forma de $\mathrm{N}$ orgânico dissolvido. Fahey et al. (2011) estudaram o transporte de $\mathrm{N}$ entre a serapilheira e o solo com o uso de folhas de Acer saccharum enriquecidas de ${ }^{15} \mathrm{~N}$ no norte dos Estados Unidos, e 
observaram que até $90 \%$ do $\mathrm{N}$ marcado foi recuperado no solo e na biomassa microbiana da camada superficial do solo. Como uma das formas de transporte de $\mathrm{N}$ entre a serapilheira e o solo, foi considerada a colonização com hifas de fungos (FAHEY et al., 2011).

A adição de EFN não teve efetiva influência na liberação de $\mathrm{N}$, pois o local onde ocorreu a decomposição não influenciou nas perdas de N. Estes resultados também foram encontrados por Castro-Díez et al. (2012) em estudo de decomposição de nativas Quercus robur e Pinus pinaster, e exóticas Eucalyptus globulus e Acacia dealbata. As espécies fixadoras, no trabalho desses autores, não aumentaram a liberação de $\mathrm{N}$ para o solo devido à composição recalcitrante do material destas espécies.

Não houve efeito da concentração de $\mathrm{N}$ na decomposição para folhas e raízes, pois embora FA e RA apresentassem maior concentração do elemento, não tiveram maiores perdas de massa do que o material do eucalipto. A ausência de efeitos do $\mathrm{N}$ na decomposição é evidenciada em outros trabalhos. Chigineva et al. (2012) estudaram a decomposição de um material com baixa concentração de N (Populus tremula) e alta concentração (Alnus glutinosa), com e sem a adição de N. Esses autores observaram que, apesar de o N adicional poder aumentar a atividade enzimática, não foi encontrada correlação entre a adição de $\mathrm{N}$ e a decomposição de ambos os materiais (CHIGINEVA et al., 2012). Partey et al. (2011) também não encontraram correlação entre a concentração de $\mathrm{N}$ e a perda de massa, em comparação entre Tithonia diversifolia e leguminosas (Senna spectabilis, Glicidia sepium, Leucaena leucocephala e Acacia auriculiformis).

Embora o material de maior concentração de $\mathrm{N}$ não tenha apresentado maior perda de massa, sua contribuição na liberação de $\mathrm{N}$ durante a decomposição é maior do que a do material de eucalipto. As folhas de acácia liberaram 79mg de $\mathrm{N}$ durante um ano de decomposição, enquanto FE, apenas $40 \mathrm{mg}$ de N. As raízes de acácia perderam 190mg de N durante o período e as de eucalipto, $57 \mathrm{mg}$ de $\mathrm{N}$. 

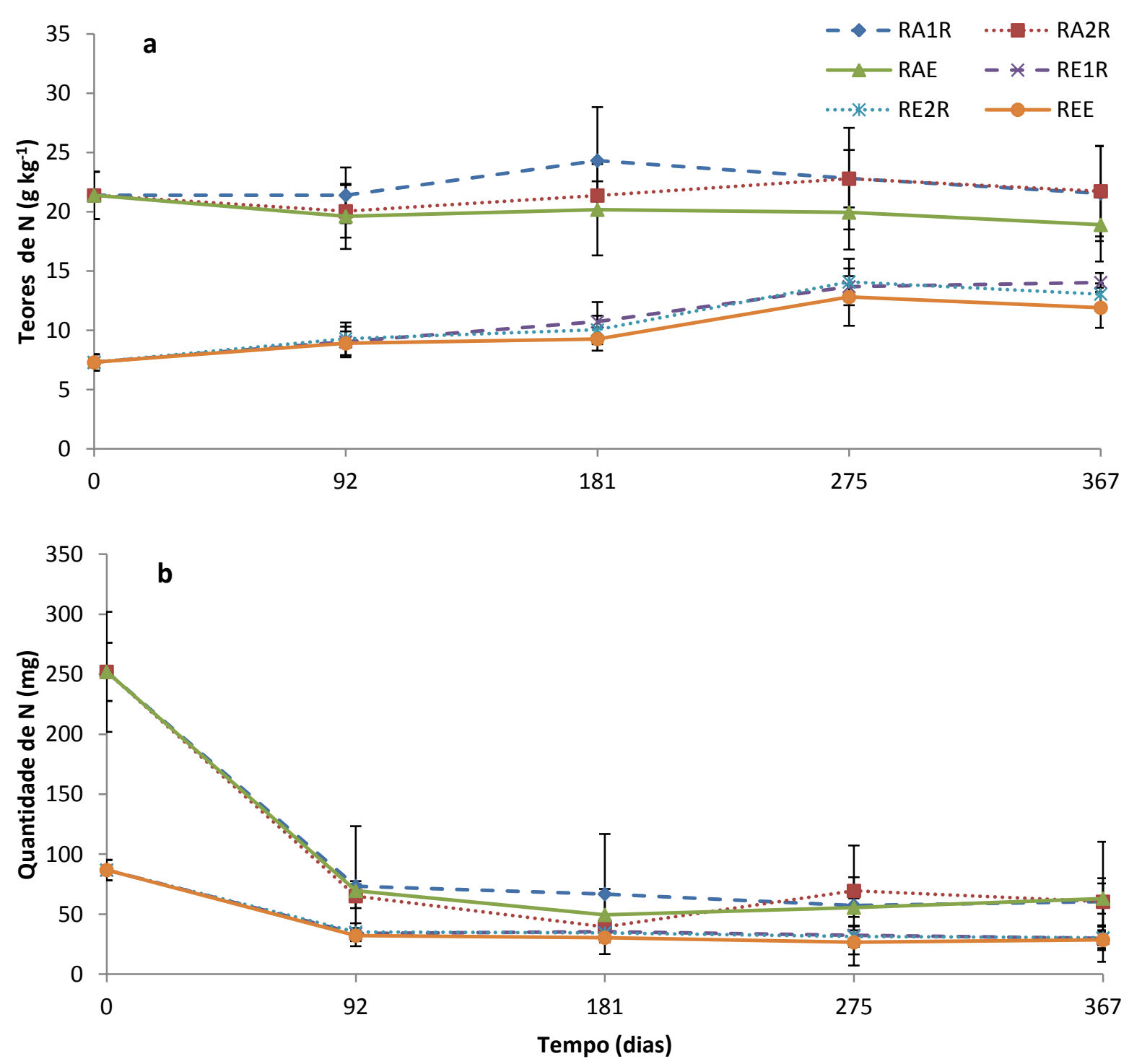

Figura 16 - Teores (a) e quantidades (b) de nitrogênio nas raízes de E. grandis e A. mangium durante o experimento de decomposição nos tratamentos RAE, RA1R, RA2R, REE, RE1R e RE2R. Os valores representam a média $(n=9) \pm$ desvio padrão

\section{- Teor e quantidade de enxofre}

Os teores de S durante os 367 dias de estudo não demonstraram padrão claro de aumento ou diminuição para folhas e raízes (Figuras 17 e 18, respectivamente). No início, FA e FE apresentaram diferença. No final do período estudado, houve diferença entre os tipos de folhas, FA e FE, com valores médios de 1,28 e $0,94 \mathrm{~g} \mathrm{~kg}^{-1}$, respectivamente. As quantidades de $\mathrm{S}$ nas folhas apresentaram inclinação de perdas no início do período e, aos 181 dias, restou, em média, $52 \%$ da quantidade de S inicial nas folhas. 
Os teores de $\mathrm{S}$ para raízes apresentaram diferença entre os tipos, RA e RE, e não houve diferenças estatisticamente significativas entre os tratamentos nos dois tipos de raízes durante todo o trabalho. As quantidades de $\mathrm{S}$ nas raízes apresentaram tendência de perdas durante os três meses iniciais e mantiveram valores significativamente diferentes entre RA e RE.

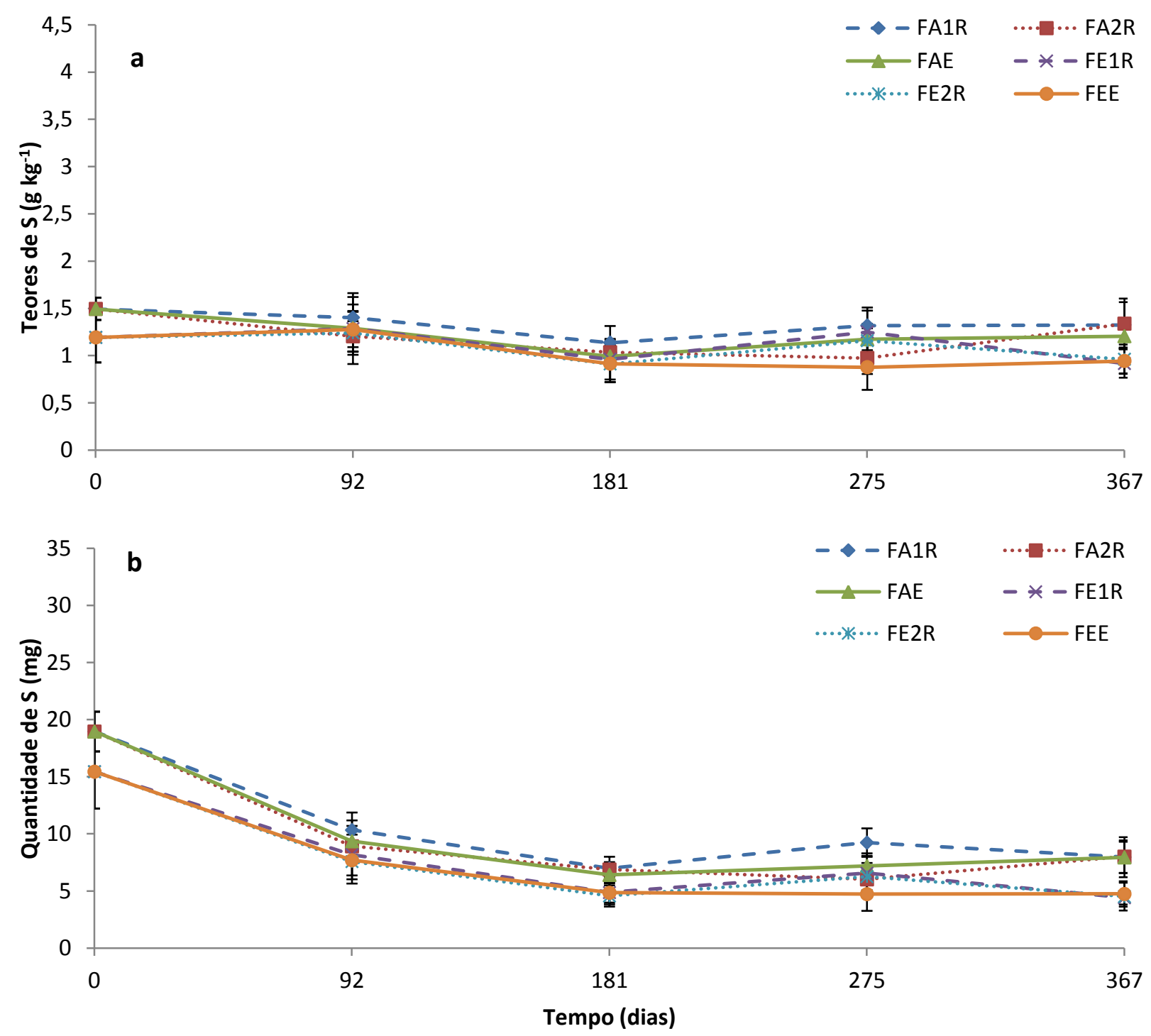

Figura 17 - Teores (a) e quantidades (b) de enxofre nas folhas de E. grandis e A. mangium durante o experimento de decomposição nos tratamentos FAE, FA1R, FA2R, FEE, FE1R e FE2R. Os valores representam a média $(n=9) \pm$ desvio padrão

Estes valores de perdas de $\mathrm{S}$ não conferem com o encontrado na literatura para decomposição de FE, em que é relatado aumento na concentração de S. Lemma et al. (2007) 
estudaram a decomposição em condições de laboratório de folhas frescas e raízes finas de Cupressus lusitanica, Pinus patula e Eucalyptus grandis, e encontraram aumento da concentração de S no material em decomposição de todas as espécies. Segundo esses autores, o incremento dos valores de $\mathrm{S}$ foi em razão da perda de massa e da imobilização deste elemento pela comunidade microbiana (LEMMA et al., 2007).
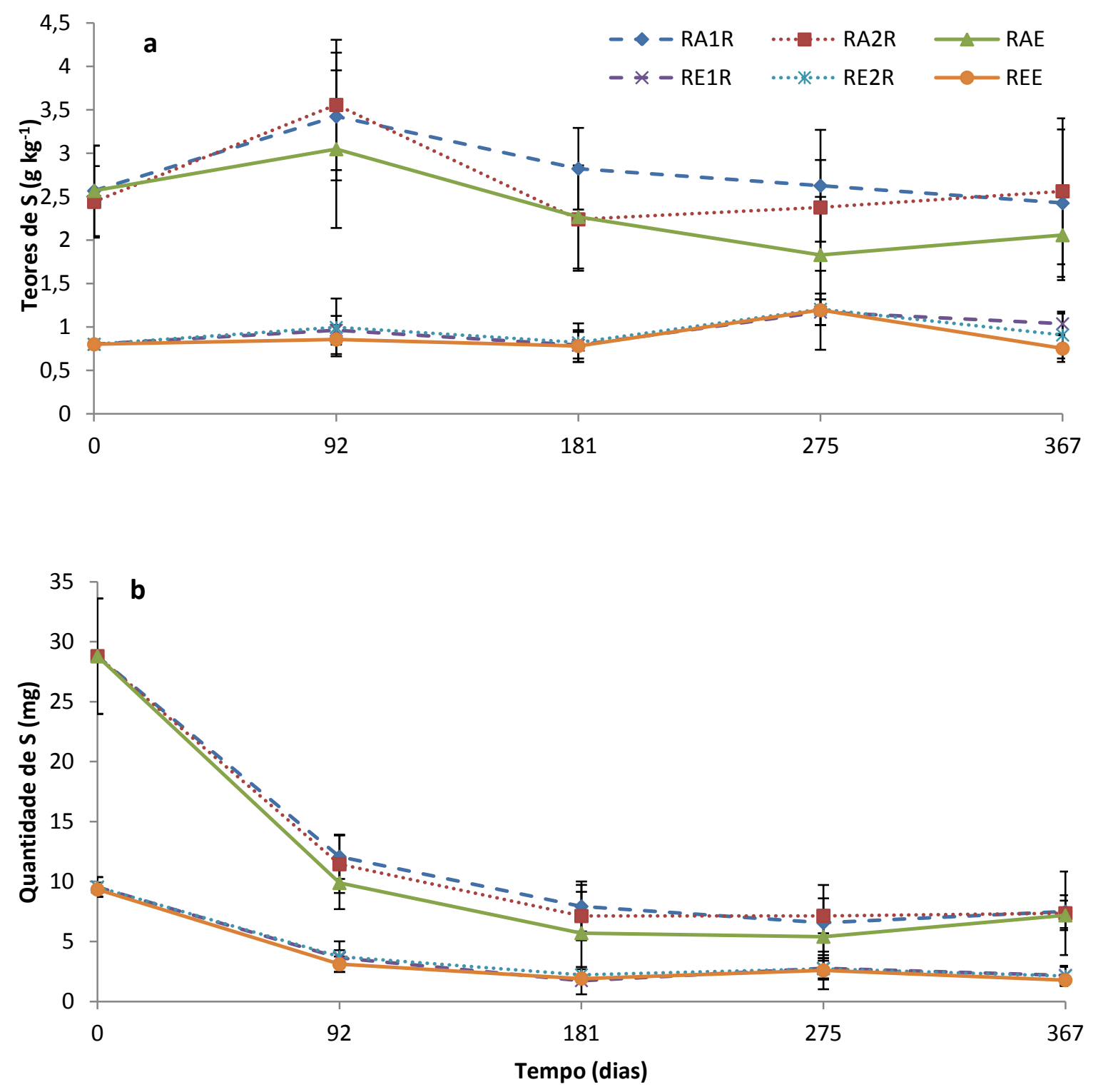

Figura 18 - Teores (a) e quantidades (b) de enxofre nas raízes de E. grandis e A. mangium durante o experimento de decomposição nos tratamentos RAE, RA1R, RA2R, REE, RE1R e RE2R. Os valores representam a média ( $n=9) \pm$ desvio padrão 


\section{- Teor e quantidade de fósforo}

Os teores de $\mathrm{P}$ para folhas (Figura 19) durante os seis meses iniciais não tiveram padrão claro, aumentando e diminuindo, assim como observado por Dickow (2010). Porém, no último período estudado, entre 181 e 367 dias, houve tendência de aumento nos valores de $\mathrm{P}$ em todos os tratamentos, sendo que não diferiram estatisticamente entre si. As quantidades de $\mathrm{P}$ em folhas seguiram o mesmo padrão de teores ao longo do tempo: aumentou $46 \%$ a partir dos 181 dias e, aos 367 dias, existiram diferenças entre os tratamentos.
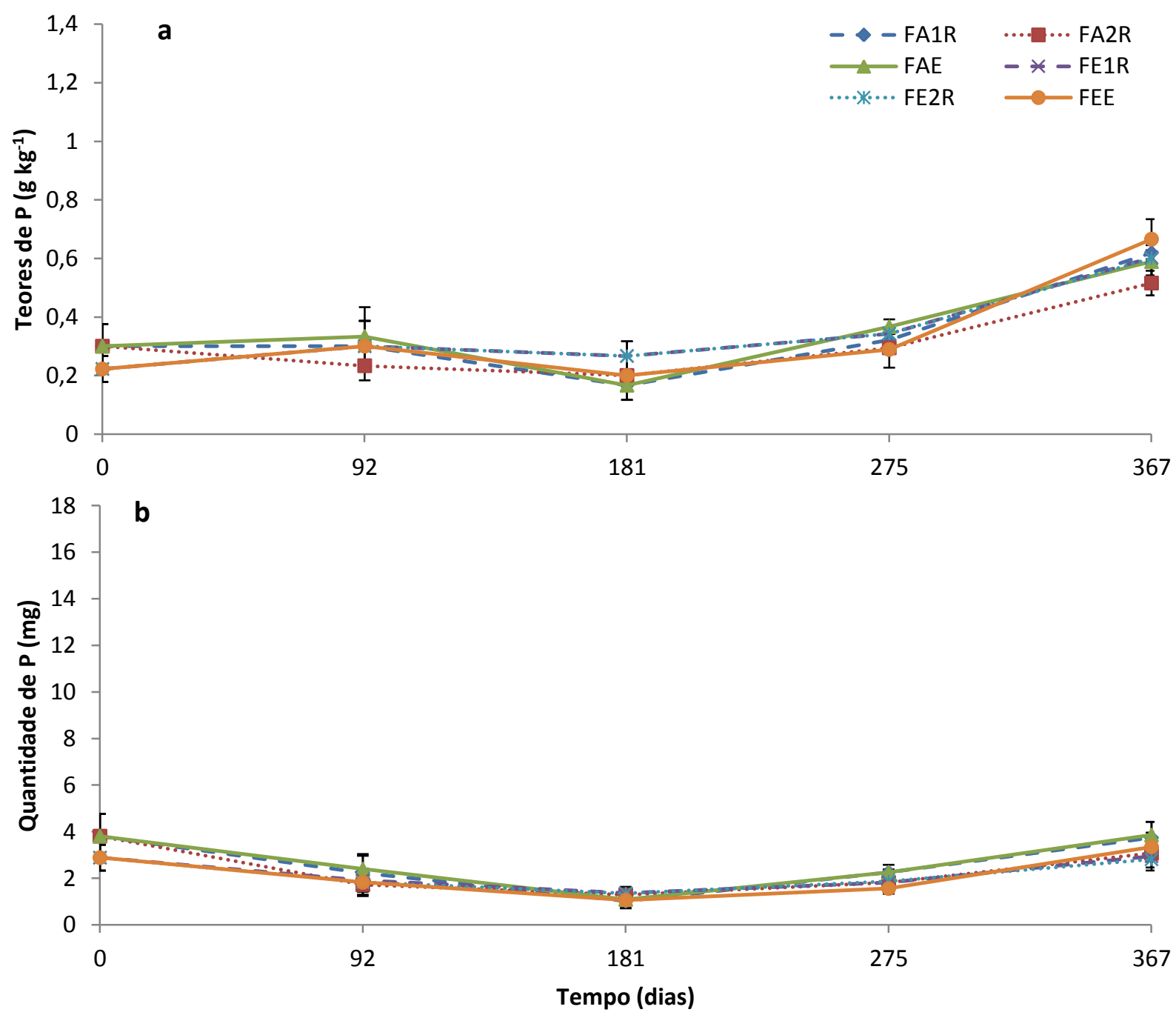

Figura 19 - Teores (a) e quantidades (b) de fósforo nas folhas de E. grandis e A. mangium durante o experimento de decomposição tratamentos FAE, FA1R, FA2R, FEE, FE1R e FE2R. Os valores representam a média $(n=9) \pm$ desvio padrão

Os teores de $\mathrm{P}$, no início, tiveram valores diferentes entre os tipos de raízes (Figura 20), mas, aos 92 dias, não houve diferença entre as médias dos tratamentos. 
Aos 367 dias, ocorreram as maiores médias do estudo, com $0,79 \mathrm{~g} \mathrm{~kg}^{-1}$ e $0,66 \mathrm{~g} \mathrm{~kg}^{-1}$ para RA e $\mathrm{RE}$, respectivamente. A quantidade de $\mathrm{P}$ em raízes teve valores iniciais distintos e, aos 92 dias, os valores se igualaram, com perda de $75 \%$ para RA e $22 \%$ para RE. Assim como para teores, as médias de quantidade não possuem diferenças estatísticas entre si e apresentaram propensão de aumento a partir dos 275 dias.
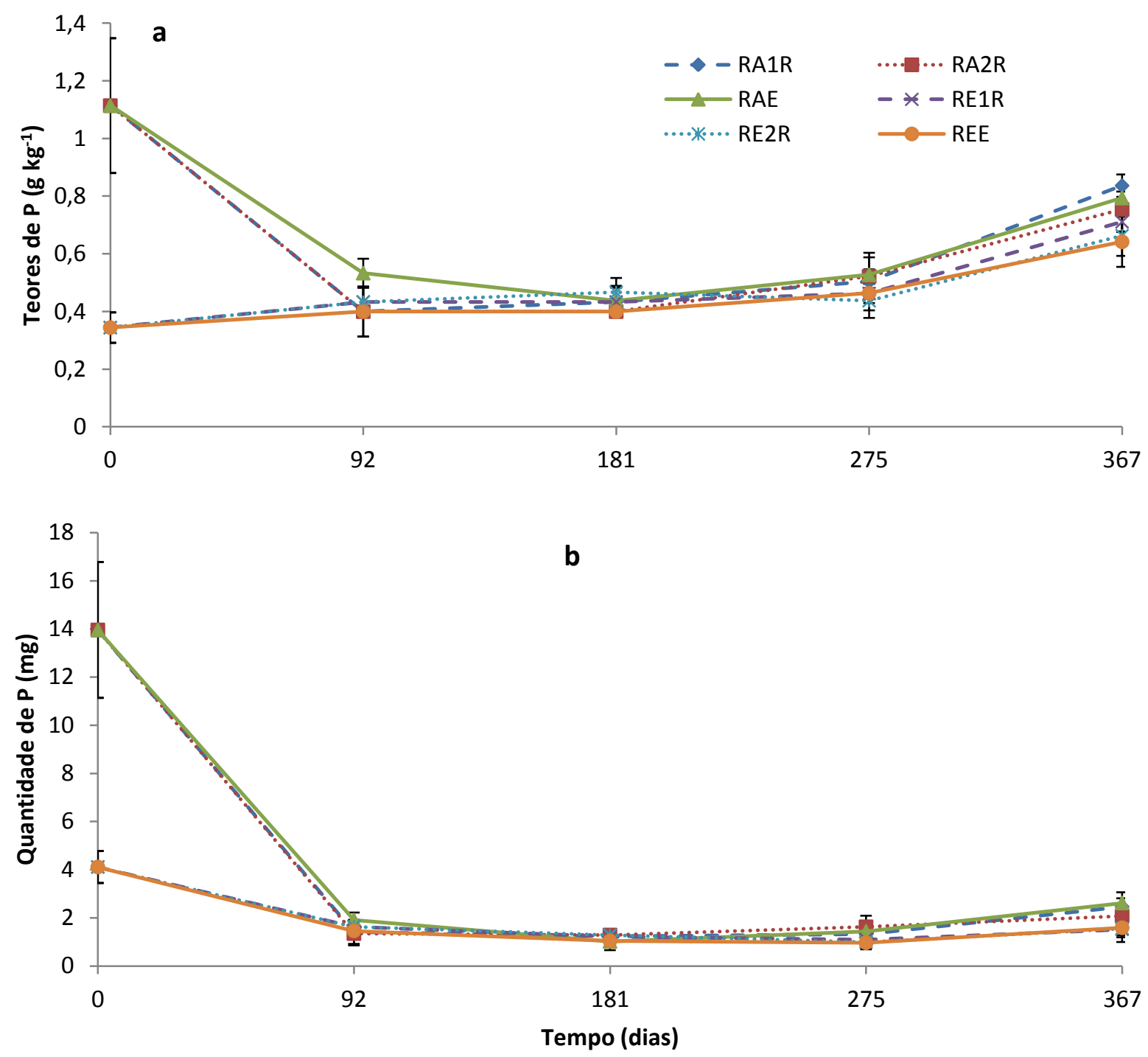

Figura 20 - Teores (a) e quantidades (b) de fósforo nas raízes de E. grandis e A. mangium durante o experimento de decomposição nos tratamentos RAE, RA1R, RA2R, REE, RE1R e RE2R. Os valores representam a média $(n=9) \pm$ desvio padrão

A forte diminuição de P em RA durante os três primeiros meses é, provavelmente, em função da liberação deste elemento para o solo. Os solos úmidos tropicais possuem baixa saturação de base em razão do alto grau de intemperismo (NOVAIS et al., 2007), conferindo 
baixa densidade de carga negativa e ocorrência de cargas positivas, pelas quais os fosfatos são fortemente absorvidos (MOTTA et al., 2002). Assim, o P forma compostos de baixa solubilidade no solo, conferindo baixos teores em solução (RAIJ et al., 2001).

O P foi o nutriente menos liberado durante a decomposição e o aumento nos valores deste elemento para as folhas durante a decomposição, tanto FA quanto FE, encontrado neste trabalho, também é relatados na literatura (LEMMA et al., 2007; HERNÁNDEZ et al., 2009, CASTELLANOS-BARLIZA; PELÁEZ, 2011), A imobilização de P durante a decomposição foi encontrada por Salas et al. (2003), em trabalho com as espécies de Sorghum bicolor e Crotalaria juncea. Esses autores sugerem que a imobilização do $\mathrm{P}$ foi ocasionada por colonização com hifas de fungos (SALAS et al., 2003).

Durante a decomposição das raízes, o P provavelmente não é limitante, pois não foi observada imobilização deste durante o estudo. Entretanto, o $\mathrm{P}$ pode ter influência na decomposição apenas a partir da segunda fase (LIN et al., 2011).

\section{- Teor e quantidade de potássio}

Os teores e as quantidades de $\mathrm{K}$ nas folhas e raízes de E. grandis e A. mangium (Figuras 21 e 22, respectivamente) mostraram grandes perdas nos três primeiros meses (92 dias), restando pequenas quantidades deste elemento ao final do período. Os teores iniciais de $\mathrm{K}$ em raízes diferiram entre RA e RE, mas aos 92 dias, não houve mais diferença estatística entre os tratamentos. Entretanto, houve uma maior liberação de K pelo material da leguminosa. As folhas de acácia liberaram, em média, 96mg de $\mathrm{K}$ durante um ano de decomposição, enquanto $\mathrm{FE}$, apenas $29 \mathrm{mg}$. As raízes de acácia perderam, em média, $41 \mathrm{mg}$ de K durante o período e as de eucalipto, $24 \mathrm{mg}$ de $\mathrm{K}$.

As rápidas perdas de $\mathrm{K}$ observadas neste trabalho também são relatadas por outros autores: para folhas de eucalipto, com perda entre 50\% e $80 \%$ nos primeiros meses de decomposição (COSTA; GAMA-RODRIGAS; CUNHA, 2005; LEMMA et al., 2007; HERNÁNDEZ et al., 2009), e também para folhas de acácia (CASTELLANOS-BARLIZA; PELÁEZ, 2011). Rápidas perdas de K no início do processo de decomposição também foram encontradas para raízes (LIN et al., 2011). 

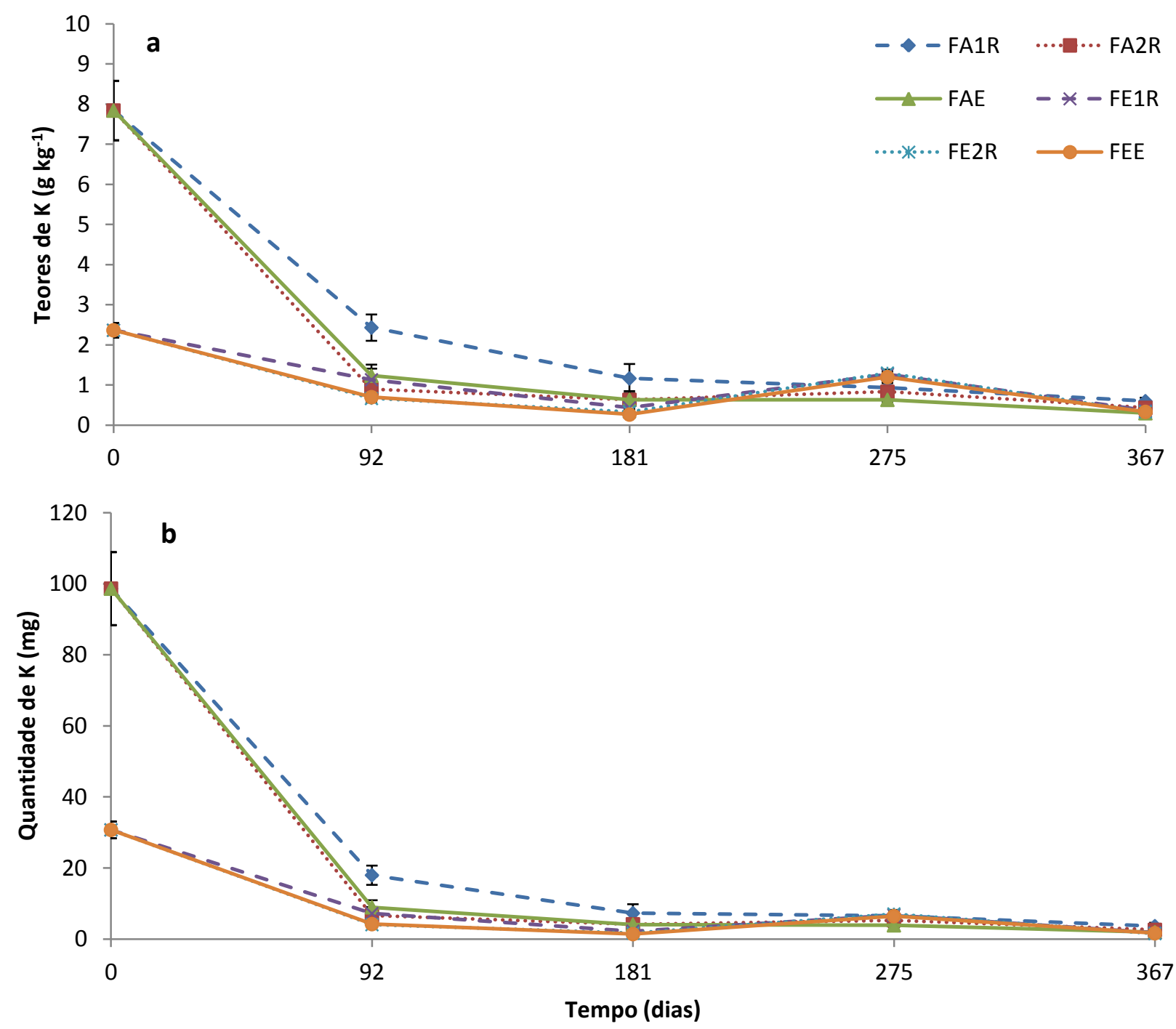

Figura 21 - Teores (a) e quantidades (b) de potássio nas folhas de E. grandis e A. mangium durante o experimento de decomposição nos tratamentos FAE, FA1R, FA2R, FEE, FE1R e FE2R. Os valores representam a média $(n=9) \pm$ desvio padrão

O K não é um elemento estrutural no tecido vegetal e também é muito móvel nas plantas, sendo facilmente lixiviado (KOLM; POGGIANI, 2003). Neste trabalho, as rápidas perdas iniciais de $\mathrm{K}$ podem ter aumentado com o período de chuvas. 

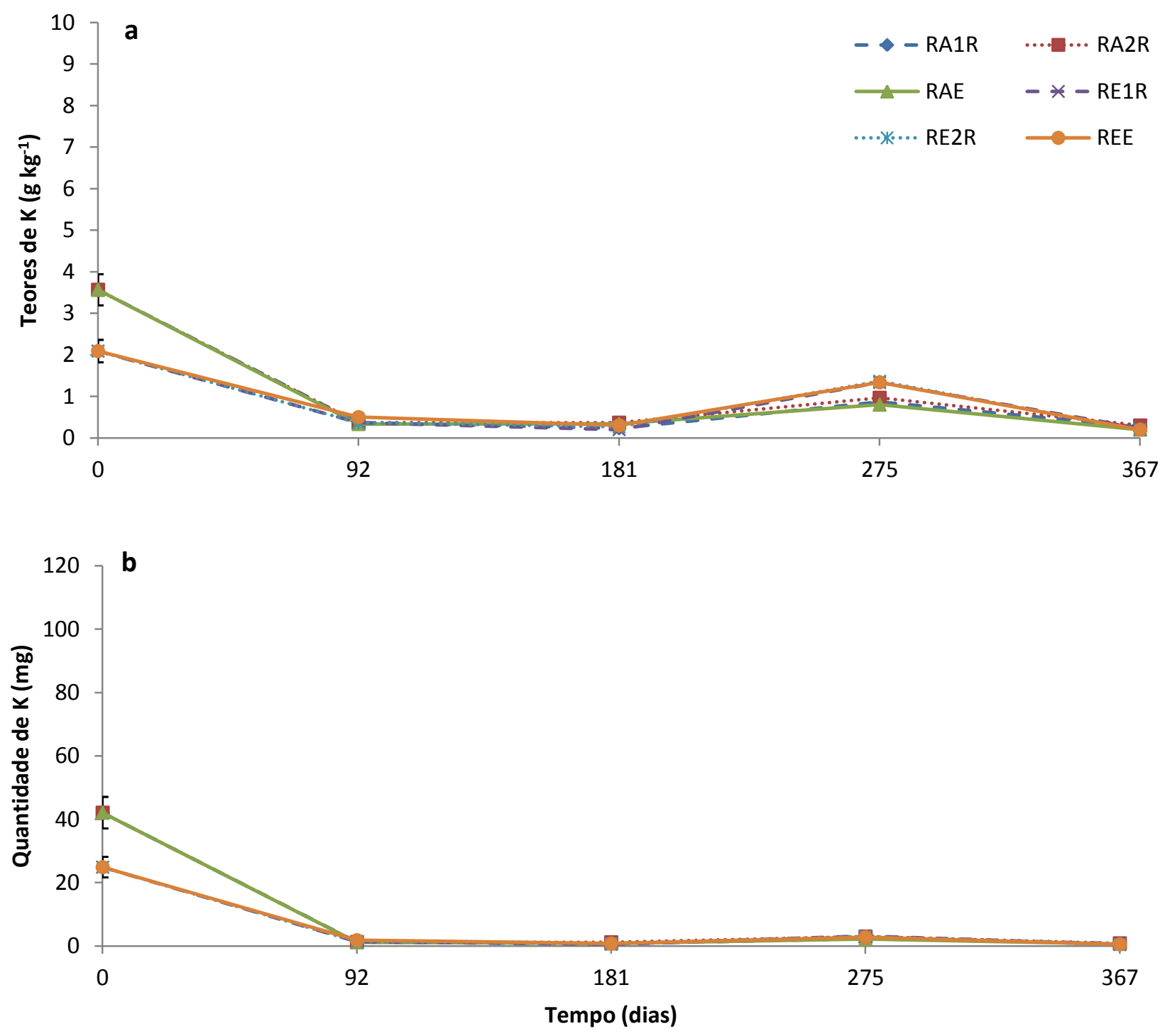

Figura 22 - Teores (a) e quantidades (b) de potássio nas raízes de E. grandis e A. mangium durante o experimento de decomposição nos tratamentos RAE, RA1R, RA2R, REE, RE1R e RE2R. Os valores representam a média $(n=9) \pm$ desvio padrão

\subsection{4 Índices de decomposição das folhas e raízes}

$\mathrm{O}$ índice de qualidade lignina/ $\mathrm{N}$ foi realizado para o tempo zero e aos 367 dias.

Os índices C/N e N/P foram realizados nas datas zero, 92, 181, 275 e 367 dias. 


\section{- Relação Lignina/N durante a decomposição}

Os valores da relação lignina/N para as folhas, no início do estudo, não apresentaram diferenças entre FA e FE (Tabela 2). Após 367 dias, os tratamentos diferiram apenas entre os tipos de folhas, sendo os menores valores para as de eucalipto (14-16), em relação às de acácia (18-20). A relação lignina/ $\mathrm{N}$ das raízes no tempo zero foi diferente entre $\mathrm{RE}$ e $\mathrm{RA}$, e ao final do período não foram observadas diferenças entre os tratamentos e entre os tipos de raízes.

Tabela 2 - Relação lignina/N nas folhas e raízes de E. grandis e A. mangium no início (n=5) e no final do experimento $(n=3)$ de decomposição ${ }^{1}$. Os resultados representam a média \pm desvio padrão ${ }^{2}$

\begin{tabular}{|c|c|c|c|}
\hline Tratamentos & Lignina/N & Tratamentos & Lignina/N \\
\hline Folhas & $\mathbf{t}=\mathbf{0}$ dia & Raízes & $\mathbf{t}=0 \mathrm{dia}$ \\
\hline FA & $23,87 \pm 1,62 \mathbf{a}$ & $\mathrm{RA}$ & $13,67 \pm 1,14 \mathbf{a}$ \\
\hline FE & $\begin{array}{c}24,50 \pm 1,14 \mathbf{a} \\
\mathbf{t}=\mathbf{3 6 7} \text { dias }\end{array}$ & $\mathrm{RE}$ & $\begin{array}{c}40,53 \pm 1,21 \mathbf{b} \\
\mathbf{t}=\mathbf{3 6 7} \text { dias }\end{array}$ \\
\hline FAE & $20,07 \pm 1,90 \mathbf{a}$ & RAE & $12,52 \pm 2,36 \mathbf{a}$ \\
\hline FA1R & $17,91 \pm 1,62 \mathbf{a b}$ & RA1R & $11,13 \pm 3,22 \mathbf{a}$ \\
\hline FA2R & $18,60 \pm 1,58 \mathbf{a b}$ & RA2R & $10,73 \pm 2,67 \mathbf{a}$ \\
\hline FEE & $14,33 \pm 2,65 \mathbf{b}$ & REE & $13,15 \pm 6,00 \mathbf{a}$ \\
\hline FE1R & $16,33 \pm 1,44 \mathbf{a b}$ & RE1R & $16,91 \pm 0,08 \mathbf{a}$ \\
\hline FE2R & $16,12 \pm 1,32 \mathbf{a b}$ & RE2R & $15,87 \pm 3,57 \mathbf{a}$ \\
\hline
\end{tabular}

A degradação da lignina é diretamente influenciada pela quantidade de $\mathrm{N}$ na serapilheira. A adição de $\mathrm{N}$ incrementa a decomposição de material com baixa lignina e retarda a degradação da serapilheira com alta concentração do composto por meio da supressão das enzimas envolvidas na degradação da lignina (PRESCOTT, 2010).

$\mathrm{O}$ parâmetro lignina/ $\mathrm{N}$ é, muitas vezes, considerado indicador dos atributos químicos do material vegetal relacionados à decomposição. John et al. (2011) estimaram a qualidade do material pela relação lignina/ $\mathrm{N}$ e encontraram correlação positiva entre material de menor relação lignina/ $\mathrm{N}$ e a velocidade de decomposição. Esses autores também utilizaram essa relação para demonstrar o predomínio na comunidade de decompositores (bactérias ou fungos) e encontraram maior diversidade de bactérias no material de menor relação lignina/N (espécies de gramíneas), em comparação à espécie arbórea (Kunzea ericoides), de maior 
relação lignina/N. A relação lignina/N foi utilizada por Ayres et al. (2009) como suporte à teoria da vantagem doméstica. No trabalho destes autores, a HFA não foi encontrada em todos os tipos de material vegetal em decomposição; entretanto, à medida que os valores de lignina/N diminuíram, a HFA foi confirmada.

\section{- Relação C/N durante a decomposição}

As relações $\mathrm{C} / \mathrm{N}$ de E. grandis e A. mangium, para folhas e raízes (Figura 23 e Anexo L), apresentaram padrão semelhante: maiores valores para eucalipto, menores para acácia e sem diferença estatística entre os tratamentos de cada tipo. Durante os seis meses iniciais, as folhas e raízes de eucalipto tiveram as maiores variações nos valores de $\mathrm{C} / \mathrm{N}$, de 72 para 52 e de 61 para 36, em FE e RE, respectivamente. Os valores de $\mathrm{C} / \mathrm{N}$ para folhas de eucalipto e acácia corresponderam aos encontrados na literatura (XIONG; BAUHUS, 2007). O material de acácia, folhas e raízes, não apresentou padrão de variação no período estudado.

Os materiais com maior relação $\mathrm{C} / \mathrm{N}$ - FE e RE - tiveram perdas de massa maiores ou iguais ao material de menor $\mathrm{C} / \mathrm{N}$. Entretanto, é relatado na literatura que materiais com alta relação $\mathrm{C} / \mathrm{N}$ (superior a 40) apresentam limitação de $\mathrm{N}$ durante a decomposição, pois os microrganismos decompositores possuem relação $\mathrm{C} / \mathrm{N}$ menor (entre 5 e 17) (PAUL; CLARK, 1996). Portanto, a relação C/N, neste estudo, não foi considerada como um bom indicador de decomposição. Hättenschwiler e Jorgensent (2010) também não encontraram correlação entre a relação $\mathrm{C} / \mathrm{N}$ e a perda de massa na mistura de serapilheira na Floresta Amazônica.

A relação $\mathrm{C} / \mathrm{N}$ encontrada no presente trabalho sugere que: (1) $\mathrm{N}$ externo ao material pode ter sido utilizado pelos microrganismos, o que é indicado pelo declínio da relação $\mathrm{C} / \mathrm{N}$ ao longo do tempo para FE e RE (ZELLER, 2000); (2) menor exigência da comunidade microbiana para $\mathrm{N}$, com prevalência de bactérias no material de alta relação $\mathrm{C} / \mathrm{N}$ (GÜSEWELL; GESSNER, 2009), e (3) maior quantidade de composto com C-decomponível no eucalipto em relação à acácia.

Zhang e Wang (2012) encontram em seu trabalho de decomposição em plantio de Cummighamia lanceolata com serapilheira da própria espécie e de Alnus cremastogune, cujo material nativo, embora de maior relação $\mathrm{C} / \mathrm{N}$ (62), teve a maior perda de massa do que os outros tipos de serapilheira com menor relação C/N (31). Os microrganismos do solo estariam adaptados na decomposição de seu próprio material, como garantia de energia e nutrientes (ZHANG; WANG, 2012). 


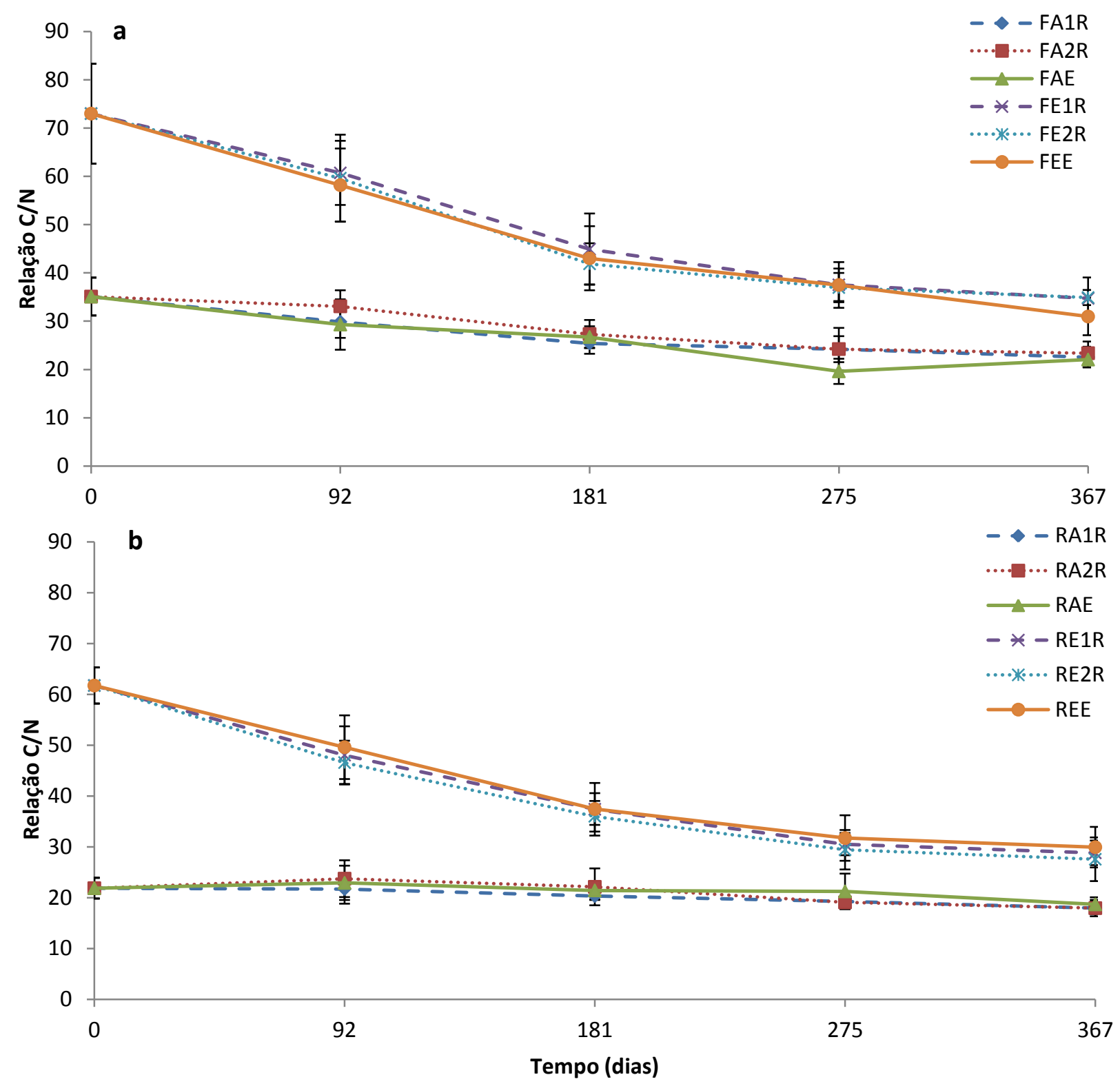

Figura 23 - Relação C/N nas folhas (a) e raízes (b) de Eucalyptus grandis e Acacia mangium durante o experimento de decomposição: a) folhas nos tratamentos FAE, FA1R, FA2R, FEE, FE1R e FE2R; b) raízes nos tratamentos RAE, RA1R, RA2R, REE, RE1R e RE2R. Os valores representam a média $(n=9)$

\section{- Relação N/P durante a decomposição}

Os valores da relação N/P para folhas de A. mangium e E. grandis (Figura 24a) aumentaram durante os seis meses iniciais de estudo, com 90 e 45, para FA e FE, respectivamente. No período seguinte, nos seis meses iniciais, em todos os tratamentos houve decréscimo dos valores e, aos 367 dias, observam-se as menores médias. Apesar de todos os tratamentos apresentarem comportamento semelhante, o material de A. mangium teve o maior 
aumento relativo aos 181 dias e também a maior perda, aos 367 dias. Na relação N/P para raízes (Figura 24b), no início do período, não houve diferença entre os tipos de material. Porém, durante o tempo do estudo, RA apresentou aumento nos valores de N/P e os tipos de raízes apresentaram diferenças. $\mathrm{O}$ aumento de N/P para folhas e raízes coincidiu com a menor quantidade de $\mathrm{P}$ durante o experimento.

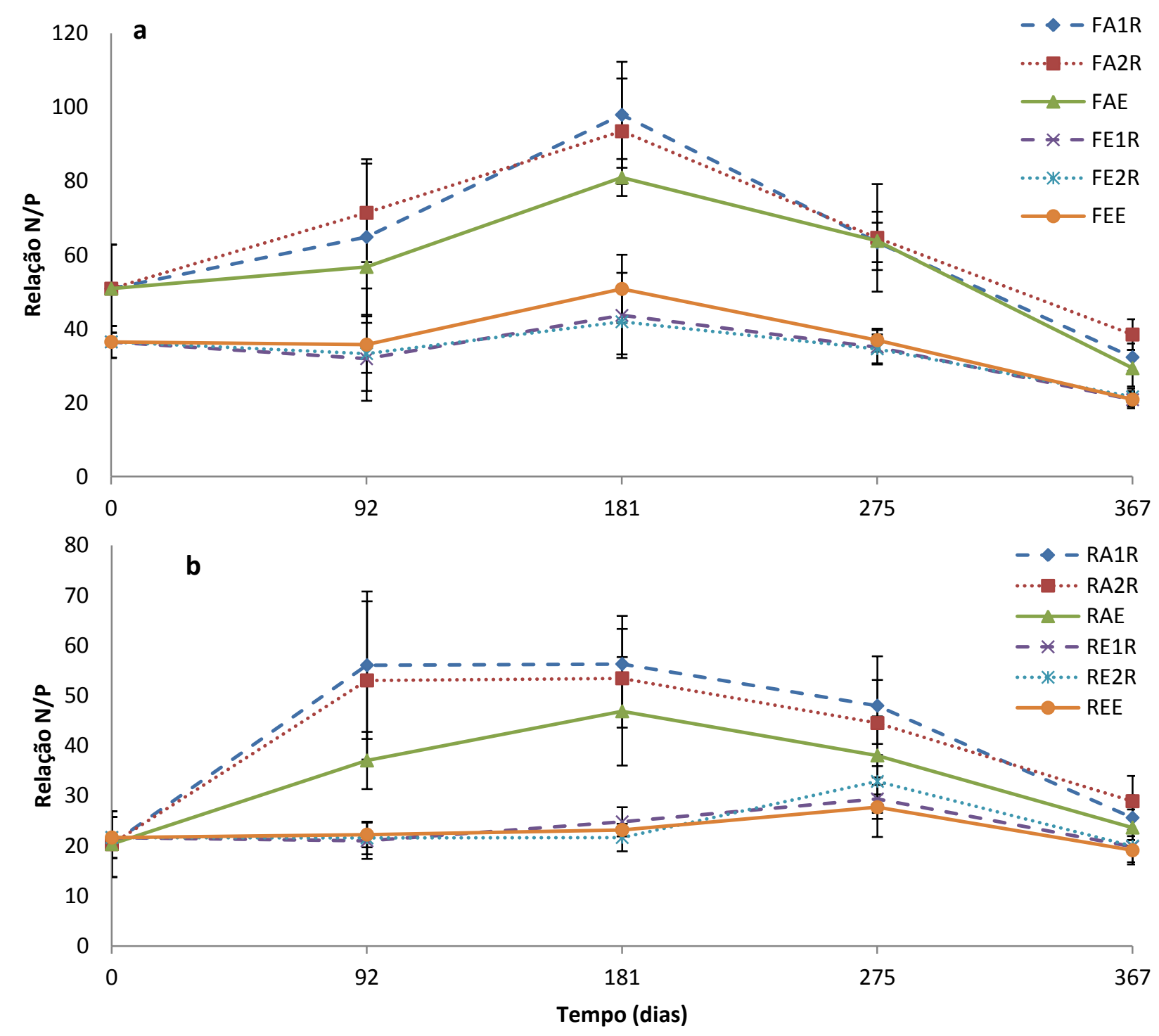

Figura 24 - Relação N/P nas folhas (a) e raízes (b) de E. grandis e A. mangium durante o experimento de decomposição: a) folhas nos tratamentos FAE, FA1R, FA2R, FEE, FE1R e FE2R; b) raízes nos tratamentos RAE, RA1R, RA2R, REE, RE1R e RE2R. Os valores representam a média $(n=9) \pm$ desvio padrão

Durante a decomposição do material da acácia, folhas e raízes, pode ter ocorrido limitação por $\mathrm{P}$, indicada pelo aumento da relação N/P durante $\mathrm{o}$ processo 
(HÄTTENSCHWILER; JORGENSENT, 2010). Partey et al. (2011) observaram aumento na relação N/P durante a decomposição de Tithonia diversifolia comparada com leguminosas, embora, para esses autores, a relação N/P tenha sido controlada apenas pela variação de N no material. Entretanto, não é possível delinear exatamente em qual momento a relação N/P é N limitante ou P limitante (GÜSEWELL; FREEMAN, 2005). A relação N/P pode fornecer informações sobre a atuação decompositora no material, conforme verificaram Güsewell e Gessner (2009), que encontraram o predomínio de bactérias em condições de baixa N/P, com a decomposição $\mathrm{N}$ limitante; em condições de alta N/P, houve superioridade na comunidade de fungos, com P limitante na decomposição (GÜSEWELL; GESSNER, 2009). No presente trabalho, é plausível ocasionar a prevalência de fungos no material de acácia, pois estes são os principais decompositores de lignina em virtude da sua capacidade de transportar nutrientes pelos micélios para o substrato em decomposição (HAMMEL, 1997). Entretanto, o valor de N/P encontrado em FA foi superior ao encontrado por Güsewell e Gessner (2009) (entre 15 e 45, para a dominância de fungos), o que pode ter ocasionado limitação no crescimento microbiano.

\subsection{5 Índices de qualidade de decomposição para folhas e raízes}

Os valores de QCL, no início, foram maiores para FE e, aos 367 dias, este material continuou a apresentar os maiores valores para o índice, embora em todos os tratamentos de folhas tenha havido diminuição dos valores (Tabelas 3 e 4). O ILC no início do período foi maior para FA e, embora aos 367 dias este índice tenha apresentado aumento nos seus valores, as folhas continuaram com diferenças significantes entre FA e FE. Esses valores para folhas correspondem ao incremento na concentração de lignina em todos os tratamentos e à menor decomposição deste composto (CORTEZ et al., 1996), principalmente para o material de acácia.

O índice QCL para raízes não apresentou diferença nos valores iniciais. No final do período de estudo, os valores de QCL nas raízes diminuíram; entretanto, REE e RE2R mantiveram os mesmos valores iniciais. Para ILC, RA apresentou maior valor inicial e, aos 367 dias, os tratamentos RE1R e RE2R não apresentaram diferença com os tratamentos de acácia. Esses resultados correspondem ao não aumento das concentrações de lignina para raízes. Constatou-se o ID para RE no maior valor no início do período; aos 367 dias, houve diminuição, mas sem diferenças estatísticas entre RA e RE. 
Tabela 3 - Índices de qualidade do material no início ( $\mathrm{t}=0$ dia) do experimento de decomposição ${ }^{1}$. Os resultados representam a média ( $\left.\mathrm{n}=5\right) \pm$ desvio padrão ${ }^{2}$

\begin{tabular}{|c|c|c|c|}
\hline \multirow[t]{2}{*}{ Tratamentos } & \multicolumn{3}{|c|}{$\mathbf{t}=\mathbf{0}$ dia } \\
\hline & Quociente holocelulose/lignocelulose - QCL & Índice ligno-celulósico - ILC & Índice de decomponibilidade - ID \\
\hline Folha Acácia & $0,49 \pm 0,03 \mathbf{b}$ & $0,63 \pm 0,04 \mathbf{a}$ & $390,32 \pm 48,22 \mathbf{a}$ \\
\hline Folha Eucalipto & $0,61 \pm 0,02 \mathbf{a}$ & $0,47 \pm 0,02 \mathbf{b}$ & $355,89 \pm 24,63 \mathbf{a}$ \\
\hline Raiz Acácia & $0,59 \pm 0,02 \mathbf{a}$ & $0,48 \pm 0,02 \mathbf{a}$ & $226,14 \pm 23,15 \mathbf{b}$ \\
\hline Raiz Eucalipto & $0,62 \pm 0,01 \mathbf{a}$ & $0,42 \pm 0,01 \mathbf{b}$ & $464,51 \pm 22,38 \mathbf{a}$ \\
\hline \multicolumn{4}{|c|}{$\begin{array}{l}{ }^{1} \text { Folhas e raízes foram comparadas separadamente. } \\
{ }^{2} \text { Médias seguidas da mesma letra não diferem estatisticamente na coluna entre folhas e entre raízes, pelo Teste de Tukey a 5\% probabilidade. }\end{array}$} \\
\hline \multicolumn{4}{|c|}{$\begin{array}{l}\text { Tabela } 4 \text { - Índices de qualidade do material vegetal de E. grandis e A. mangium no final do experimento de decomposição }{ }^{1} \text { (t= } 367 \text { dias) nos } \\
\text { tratamentos de folhas FAE, FA1R, FA2R, FEE, FE1R e FE2R, e nos tratamentos de raízes RAE, RA1R, RA2R, REE, RE1R e RE2R. Os } \\
\text { resultados representam a média }(n=3) \pm \text { desvio padrão }{ }^{2}\end{array}$} \\
\hline \multirow[t]{2}{*}{ Tratamentos } & \multicolumn{3}{|c|}{$t=367$ dias } \\
\hline & Quociente holocelulose/lignocelulose - QCL & Índice ligno-celulósico - ILC & Índice de decomponibilidade - ID \\
\hline \multicolumn{4}{|c|}{ 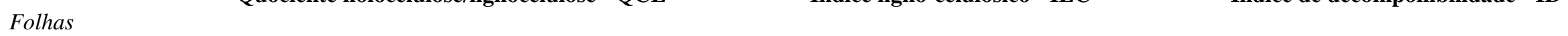 } \\
\hline FAE & $0,42 \pm 0,01 \mathbf{b}$ & $0,71 \pm 0,01 \mathbf{a}$ & $123,03 \pm 11,65 \mathbf{a b}$ \\
\hline FA1R & $0,40 \pm 0,01 \mathbf{b}$ & $0,72 \pm 0,01 \mathbf{a}$ & $120,38 \pm 10,88 \mathbf{a b}$ \\
\hline FA2R & $0,41 \pm 0,02 \mathbf{b}$ & $0,72 \pm 0,01 \mathbf{a}$ & $126,88 \pm 11,67 \mathbf{a}$ \\
\hline FEE & $0,54 \pm 0,02 \mathbf{a}$ & $0,60 \pm 0,01 \mathbf{b}$ & $93,85 \pm 17,33 \mathbf{b}$ \\
\hline FE1R & $0,55 \pm 0,02 \mathbf{a}$ & $0,57 \pm 0,05 \mathbf{b c}$ & $108,42 \pm 8,78 \mathbf{a b}$ \\
\hline FE2R & $0,56 \pm 0,01 \mathbf{a}$ & $0,53 \pm 0,01 \mathbf{c}$ & $108,44 \pm 9,66 \mathbf{a b}$ \\
\hline \multicolumn{4}{|l|}{ Raízes } \\
\hline RAE & $0,45 \pm 0,01 \mathbf{b}$ & $0,65 \pm 0,03 \mathbf{a}$ & $75,58 \pm 14,28 \mathbf{a}$ \\
\hline RA1R & $0,47 \pm 0,04 \mathbf{b}$ & $0,66 \pm 0,04 \mathbf{a}$ & $68,13 \pm 19,68 \mathbf{a}$ \\
\hline RA2R & $0,49 \pm 0,05 \mathbf{b}$ & $0,62 \pm 0,06 \mathbf{a}$ & $67,16 \pm 16,07 \mathbf{a}$ \\
\hline REE & $0,60 \pm 0,04 \mathbf{a}$ & $0,49 \pm 0,02 \mathbf{b}$ & $77,07 \pm 35,15 \mathbf{a}$ \\
\hline RE1R & $0,50 \pm 0,02 \mathbf{b}$ & $0,58 \pm 0,02 \mathbf{a}$ & $108,01 \pm 0,54 \mathbf{a}$ \\
\hline RE2R & $0,52 \pm 0,02 \mathbf{a b}$ & $0,57 \pm 0,01 \mathbf{a b}$ & $94,76 \pm 21,31 \mathbf{a}$ \\
\hline
\end{tabular}

${ }^{\mathrm{I}}$ Folhas e raízes foram comparadas separadamente.

${ }^{2}$ Médias seguidas da mesma letra na coluna não diferem estatisticamente pelo Teste de Tukey a 5\% probabilidade. 
Estes índices refletem as características da composição química do material, as quais, para as folhas, permaneceram distintas ao longo do período estudado; nas raízes, não existiu padrão claro na composição destes compostos. Este fato repete o mesmo padrão de perda de massa observado durante o trabalho para folhas e raízes. Pavei (2005) qualificou a decomponibilidade dos resíduos de aveia branca, soja e trigo durante diferentes tipos de preparo do solo e não observou diferença entre os índices, pois, em seu trabalho, não houve alterações significativas na composição dos resíduos.

Esses índices apresentam ligação entre dois componentes importantes no controle da decomposição: celulose e lignina. A celulose pode ser usada como fonte de C para os microrganismos, suavizando a limitação de C durante a decomposição (WAKSMAN; STARKEY, 1924), e a lignina é normalmente um composto que impede a degradação do material vegetal, por ser resistente à decomposição (BERG; McCLAUGHERTY, 2003). Entretanto, quando combinados, esses compostos se relacionam, pois a celulose atua como um iniciador da degradação da lignina. Talbot e Treseder (2012) observaram que, apesar de a celulose não controlar efetivamente a perda de massa do material vegetal, ela proporcionou a degradação da lignina nas folhas em que havia maior concentração de celulose.

\subsection{Experimento B}

\subsubsection{N-total nas folhas durante a transferência de $\mathrm{N}$}

A quantidade de $\mathrm{N}$ nas folhas fonte, tanto de eucalipto como de acácia, apresentou durante o período estudado uma tendência linear (Figura 24). Portanto, foi admissível que ocorressem poucas perdas de $\mathrm{N}$ durante a decomposição ou a imobilização de $\mathrm{N}$, também evidenciadas em outros trabalhos (BLAIR; CROSSLEY; CALLAHANA, 1992, VALENZUELA-SOLANO; CROHN, 2006). Os diferentes tipos de combinações entre os pares de folhas não apresentaram diferenças nos teores finais de N, com exceção apenas para o tipo de folha, FA ou FE, que teve diferença significativa. Schimel e Hättenschwiler (2007), em estudo sobre transferência de $\mathrm{N}$ durante a decomposição de pares de folhas, observaram que as folhas tiveram maiores concentrações finais de $\mathrm{N}$ total quando pareadas com folhas de alta concentração do que com folhas de baixa concentração de $\mathrm{N}$. 


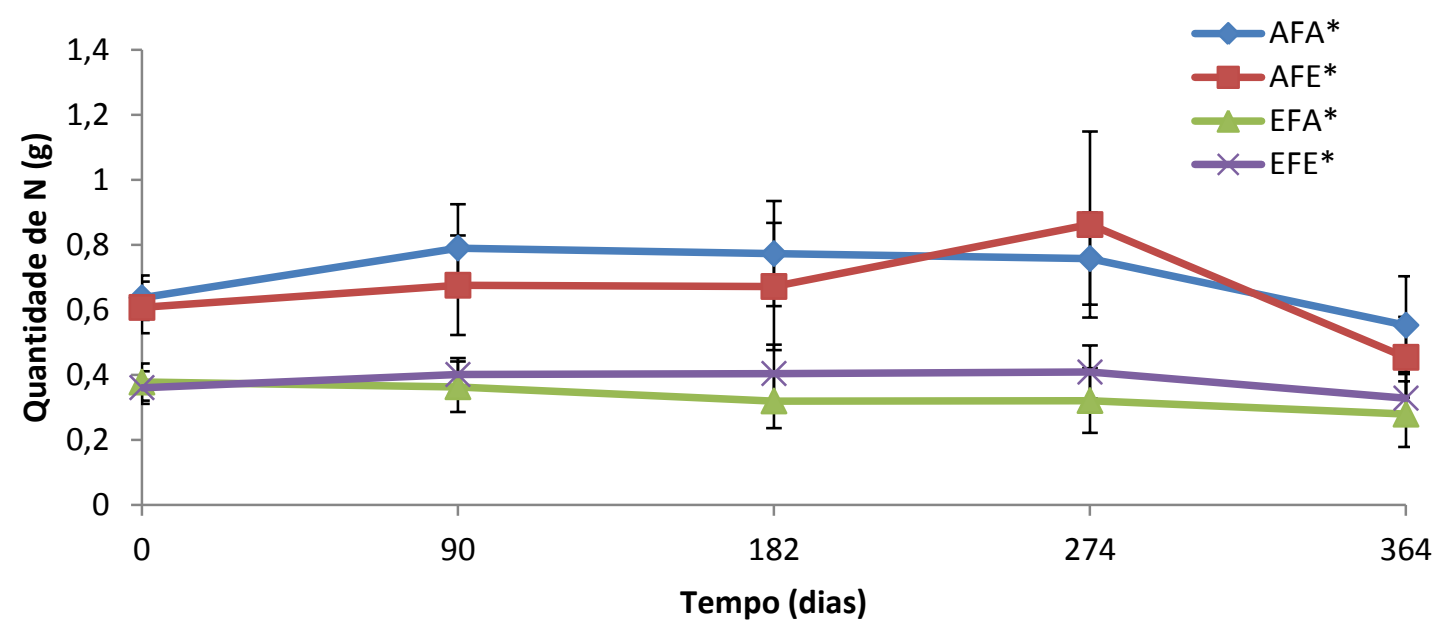

Figura 25 - Fluxos de quantidade (g) de nitrogênio total durante o experimento de transferência de $\mathrm{N}$ entre os tratamentos drenos AFA*, AFE*. EFA* e EFE*. Os valores representam a média $(n=4) \pm$ desvio padrão

\subsubsection{Taxa de transferência de $\mathbf{N}$ entre as folhas durante a decomposição}

A taxa de transferência de $\mathrm{N}$ entre as folhas em decomposição (Figura 25) apresentou diferença significativa entre os tratamentos de drenos. No primeiro período, 90 dias, a maior transferência de $\mathrm{N}$ foi para as folhas de acácia (82\%), independentemente da fonte. Entretanto, ao longo do estudo, a transferência de $\mathrm{N}$ para FA foi intensificada quando a fonte foi $\mathrm{FE}$, com valores de $65 \%$ e $100 \%$ com fonte de FA e FE, respectivamente. Aos 364 dias, houve diferença apenas entre os tratamentos de drenos FA e FE $(p=0,007)$. As folhas de eucalipto como dreno apresentaram as menores taxas de transferência, sem influência do tipo de folha fonte, com média de $20 \%$ de transferência. A partir dos 182 dias, considerou-se que houve transferência líquida de $\mathrm{N}$ entre FA e FE de $70 \%$. O fluxo de $\mathrm{N}$ entre as folhas pode ser bidirecional, principalmente quando ocorre colonização por hifas de fungos (FREY; SIX; ELLIOTT, 2003; HOOBIE; HOBBIE, 2006; FAHEY et al., 2011).

A transferência de $\mathrm{N}$ guiada pela diferença entre as concentrações de $\mathrm{N}$ das folhas não foi observada neste trabalho. Schimel e Hättenschwiler (2007), em trabalho sobre a transferência de $\mathrm{N}$ entre folhas com diferentes concentrações de $\mathrm{N}$, encontraram a maior taxa entre as folhas de maior concentração de N para as de menor concentração. Entretanto, esses autores não explicam este fato pela diferença de concentrações dos pares de folhas e sim por meio da teoria clássica da mineralização, segundo a qual os microrganismos teriam o primeiro 
acesso ao $\mathrm{N}$ e controlariam a quantidade de $\mathrm{N}$ que posteriormente seria liberada (SCHIMEL; BENNET, 2004). O dreno foi o controle do deslocamento de $\mathrm{N}$, diferentemente do encontrado por Schimel e Hättenschwiler (2007), em que a fonte de $\mathrm{N}$ orientou a transferência. A permuta de $\mathrm{N}$ entre folhas da mesma espécie foi encontrada por esses autores, assim como no presente trabalho.

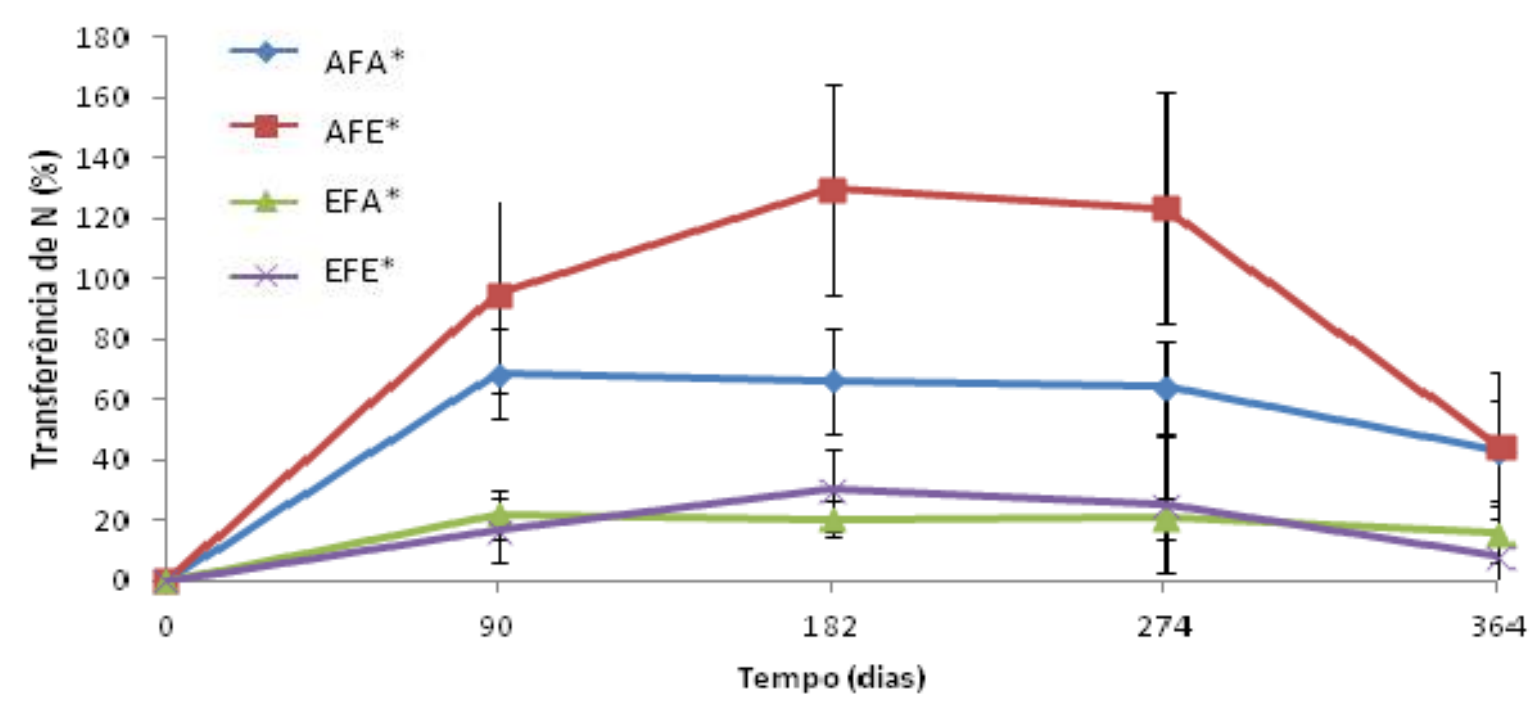

Figura 26 - Transferência de $\mathrm{N}$ entre as folhas nos tratamentos de drenos AFA*, AFE*, EFA* e EFE*. Os valores representam a média $(n=4) \pm$ desvio padrão

A maior transferência controlada pelas folhas de acácia como dreno ocorreu em função da situação limitada de $\mathrm{N}$ que a comunidade microbiana encontrou neste material. Apesar da maior concentração bruta de $\mathrm{N}$ em FA, este elemento pode não estar disponível aos microrganismos que utilizam uma fonte externa de N (TALBOLT; TRESEDER, 2012). O estabelecimento da comunidade de bactérias e fungos no material da acácia em curto prazo não foi estimulado pelo longo período de sucessivas rotações de eucalipto, que ocorreram no local. Ayres et al. (2009) observaram que o aparecimento da teoria da vantagem doméstica foi relacionado à capacidade de colonização dos decompositores, o que não ocorreu com as espécies recentemente implantadas no local do estudo. Além disso, a colonização dos microrganismos pode ocorrer com vantagem em determinados substratos, impossibilitando a liberação de N neste material. John, Orwin e Dickie (2010) sugerem que a colonização dos decompositores é pouco controlada pelo local, tal controle dar-se-ia, preferencialmente, pela composição química do material. Assim, o material do eucalipto se apresentou como fonte de $\mathrm{N}$ por ser um material mais facilmente decomponível e ter disponibilidade de $\mathrm{N}$; ou, ainda, a 
comunidade microbiana do local mostrar-se selecionada para adquirir mais facilmente o $\mathrm{N}$ presente nas folhas do eucalipto. 


\section{CONCLUSÕES}

\subsection{Experimento A}

A teoria da vantagem doméstica em curto período não foi observada, pois o local onde ocorreu a decomposição (plantio de eucalipto, plantio de acácia primeira rotação ou plantio de acácia em segunda rotação) não influenciou no processo durante esta primeira fase. A cobertura da vegetação tem a capacidade de modificar a comunidade microbiana do solo e incrementar o decaimento dos seus resíduos; entretanto, este efeito pode acontecer em longo prazo e os tratamentos de acácia ainda seriam recentes para tal modificação.

A concentração inicial de nitrogênio não influenciou positivamente na decomposição e o material com maior teor de $\mathrm{N}$ teve a decomposição mais lenta, para folhas, ou igual, para raízes. A composição de compostos orgânicos, como os carboidratos estruturais ou os facilmente decomponíveis, teve maior influência na porcentagem de massa remanescente do que a concentração inicial dos macroelementos. A lignina foi o componente que apresentou maior resistência na decomposição do material, permanecendo a concentração final semelhante à inicial, embora as quantidades tenham se diferenciado entre os tipos de materiais, FA, FE, RA e RE.

As relações lignina/N e $\mathrm{C} / \mathrm{N}$ não puderam ser utilizadas como parâmetro de decomposição. Entretanto, a relação N/P é capaz de indicar o predomínio entre bactérias e fungos da comunidade decompositora. A primeira demanda da decomposição foi energética, demonstrada pela variação da composição do material, sendo, posteriormente, nutricional. O fósforo foi o elemento que pode ter limitação da decomposição a partir dos 181 dias de experimento, pelo aumento dos teores e quantidades. 


\subsection{Experimento B}

A transferência de $\mathrm{N}$ via serapilheira entre espécies fixadoras de nitrogênio e espécies não fixadoras ocorreu em condições de campo e a rápida troca de $\mathrm{N}$ entre as folhas no começo do período pode ter sido incrementada com a fase inicial de decomposição e as condições de alta pluviosidade e temperatura em que o experimento foi instalado.

O controle da transferência deu-se quando as folhas de acácia atuaram como tipo folha dreno, independentemente da fonte ou da diferença de concentração de $\mathrm{N}$ entre o par de folhas. Após permanecer décadas com plantio de eucalipto, o ambiente onde ocorreu o estudo pode ter limitado a ação dos decompositores presentes no material então recentemente incorporado na área, as folhas da acácia. A maior transferência de $\mathrm{N}$ de FE para FA foi incrementada pelas condições limitantes para aquisição de $\mathrm{N}$ no material da própria leguminosa. Apesar de haver maior quantidade de $\mathrm{N}$ em FA, este elemento possivelmente não está facilmente disponível para o uso dos microrganismos. As folhas da leguminosa apresentaram maior concentração inicial de lignina e, após 367 dias de decomposição, permaneceram mais de $70 \%$ da quantidade deste componente que, além de ser negativamente correlacionado com a perda de massa, tem a capacidade de proteger as proteínas da quebra microbiana, indisponibilizando o $\mathrm{N}$. 


\section{CONSIDERAÇÕES FINAIS DOS EXPERIMENTOS}

A adição de EFN em uma monocultura de eucalipto pode influenciar a decomposição da serapilheira; entretanto, este fato depende do estabelecimento de uma comunidade microbiana capaz de quebrar os constituintes de ambos os materiais vegetais. A área de estudo passou sucessivos anos com cobertura vegetal apenas de eucalipto, o que levou a especialização do solo e sua comunidade decompositora a agirem sobre sua própria serapilheira, considerada recalcitrante e com alta relação $\mathrm{C} / \mathrm{N}$. O material de A. mangium, apesar de apresentar maior quantidade de N, não foi facilmente decomponível neste local, mesmo que em segunda rotação desta espécie, como foi observado no Experimento A. O N contido na acácia pode não estar disponível aos decompositores presentes, que, por sua vez, não são eficientes na degradação da leguminosa. Como tentativa de supressão da limitação de $\mathrm{N}$ durante a decomposição, houve maior transferência do elemento para FA, principalmente quando pareadas com FE, como foi observado no Experimento B. A relação C/N não pode ser considerada neste trabalho como parâmetro para decomposição, pois FA aprestou o valor equivalente ao dobro de FE. A relação N/P também não foi relacionada com a perda de massa e sim com as características da comunidade microbiana, da prevalência de bactérias ou fungos. 


\section{REFERÊNCIAS}

ASSOCIAÇÃO BRASILEIRA DE PRODUTORES DE FLORESTAS PLANTADAS ABRAF. Anuário estatístico da ABRAF 2011 ano base 2010. Brasília: ABRAF, 2010. 130 p.

AITA, C.; GIACOMINI, S. J. Matéria orgânica do solo, nitrogênio, e enxofre nos diversos sistemas de exploração agrícola. In: YAMADA, T.; ABDALLA, S. R. S.; VITTI, G. C. (Eds.). Nitrogênio e enxofre na agricultura brasileira. Piracicaba: IPNI Brasil, 2007. 722 p.

AYRES, E.; DROMPH, K. M.; BARDGETT, R. D. Do plant species encourage soil biota that specialize in the rapid decomposition of their litter? Soil Biology \& Biochemistry, Oxford, v. 38, n. 1, p. 183-186, 2006.

AYRES, E.; STELTZER, H.; BERG, S.; WALL, D.H. Soil biota accelerate decomposition in high-elevation forests by specializing in the breakdown of litter produced by the plant species above them. Journal of Ecology, Oxford, v. 97, n. 5, p. 901-912, 2009.

BAKKER, M. A.; CARREÑO-ROCABADO, G.; POORTER, L. Leaf economics traits predict litter decomposition of tropical plants and differ among land use types. Functional Ecology, Oxford, v. 25, n. 3, p. 473-483, 2011.

BALIEIRO, F. C.; DIAS, L. E.; FRANCO, A. A.; CAMPELlO, E. F. C.; FARIA, S.M. Acúmulo de nutrientes na parte aérea, na serapilheira acumulada sobre o solo e decomposição de filódios de Acacia mangium Willd. Ciência Florestal, Santa Maria, v. 14, n. 1, p. 59-65, 2003.

BALIEIRO, F. C.; FRACO, A. A.; PEREIRA, M. G. CAMPELlO, E. F. C.; DIAS, L. E.; FARIA, S. M.; ALVES, B. J. R. Dinâmica da serapilheira e transferência de nitrogênio ao solo, em plantios de Pseudosamanea guachapele e Eucalyptus grandis. Pesquisa Agropecuária Brasileira, Brasília, v.39, n.6, p.597-601, 2004.

BALIEIRO, F. C.; ALVES, B. J. R.; PEREIRA, M. G.; FARIA, S. M.; FRANCO, A. A.; CAMPELLO, E. F. C. Biological nitrogen fixation and nutrient release from litter of the guachapele leguminous tree under pure and mixed plantation with eucalyptus. Cerne, Lavras, v. 14, n. 3, p. 185-193, 2008.

BARANTAL, S.; ROY, J.; FROMIN, N.; SCHIMANN, H.; HÄTTENSCHWILER. S. Longterm presence of tree species but not chemical diversity affect litter mixture effects on decomposition in a neotropical rainforest. Oecologia, Berlin, v. 167, n. 1, p. 241-251, 2011.

BÄRLOCHER, F. Leaf mass loss estimated by litter bag technique. In: GRAÇA, M. A. S.; BÄRLOCHER, F.; GESSENER, M. (Eds.) Methods to study litter decomposition: a pratical guide. Dordrecht: Springer, 2005. p. 37-42.

BAUHUS, J; KHANNA, P. K.; MENDEN, N. Aboveground and belowground interactions in mixed plantations of Eucalyptus globulus and Acacia mearnsii. Canadian Journal of Chemistry, Ottawa, v. 30, n. 12, p. 1886-1894, 2000. 
BAUMANN, K.; MARSCHNER, P.; SNERNIK, R. J.; BALDOCK, J. A. Residue chemistry and microbial community structure during decomposition of eucalypt, wheat and vetch residues. Soil Biology and Biochemistry, Oxford, v. 41, n. 9, p. 1966-1975, 2009.

BAUMANN, K.; MARSCHNER, P.; SNERNIK, R. J.; BALDOCK, J. A. Microbial community structure and residue chemistry during decomposition of shoots and roots of young and mature wheat (Triticum aestivum L.) in sand. European Journal of Soil Science, Oxford, v. 62, n. 5, p. 666-675, 2011.

BERG, B.; EKBOHM, G.; McCLAUGHERTY, C. Lignin and holocellulose relations during long term decomposition of some forest litters: Long- term decomposition in a Scots-pine forest. IV. Canadian Journal of Botany, Ottawa, v. 62, n. 12, p. 2540-2550, 1984.

BERG, B. Nutrient release from litter and humus in coniferous forest soil: a mini review. Scandinavian Journal of Forest Research, New York, v. 1, n. 1-4, p. 359-369, 1986.

BERG, B.; MATZNER, E. Effect of N deposition on decomposition of plant litter and soil organic matter in forest systems. Environmental Review, Denver, v. 5, n. 1, p. 1-25, 1997.

BERG, B; McClAUGHERTY, C. Plant litter: decomposition, humus formation, carbon sequestration. Berlin: Springer Verlag, 2003, 286 p.

BLAIR, J. M.; CROSSlEY, D. A.; CALLAHANA, C. Effects of litter quality and microarthropods on $\mathrm{N}$ dynamics and retention of exogenous $15 \mathrm{~N}$ in decomposition litter. Biology and Fertility of Soils, Berlin, v. 12, n. 4, p. 241-252, 1992.

BODDEY, R. M. PEOPLES, M. B.; PALMER, B.; DART, P. J. Use of ${ }^{15} \mathrm{~N}$ natural abundance technique to quantify biological nitrogen fixation by Woody perennial. Nutrient Cycling in Agroecosystems, Amsterdam, v. 57, n. 3, p. 235-270, 2000.

BOUILLET, J. P; LACLAU, J. P.; GONÇALVES, J. L. M.; MOREIRA, M. Z.; TRIVELIN, P. C. O.; JOURDAN, C.; SILVA, E. V.; PICCOLO, M. C.; TSAI, S. M.; GALIANA, A. Mixed-species plantations of Acacia mangium and Eucalyptus grandis in Brazil 2: Nitrogen accumulation in the stands and biological $\mathrm{N}_{2}$ fixation. Forest Ecology and Management, Amsterdam, v. 255, n. 12, p. 3918-3930, 2008.

BRIONES, M. J. I.; INESON, P. Decomposition of eucalyptus leaves in litter mixtures. Soil Biology \& Biochemistry, Oxford, v. 28, n. 10-11, p. 1381-1388, 1996.

CALVI, G. P.; PEREIRA, G. M.; JUNIOR, A. E. Produção da serapilheira e o aporte de nutrientes em área de floresta atlântica em Santa Maria de Jetibá, ES. Ciência Florestal, Santa Maria, v. 19, n. 2, p. 131-138, 2009.

CANHOTO, C.; GRAÇA, M. A. S. Decomposition of Eucalyptus globulus leaves and three native leaf species (Alnus glutinosa, Castanea sativa and Quercus faginea) in a Portuguese low order stream. Hydrobiology, Berlin, v. 333, n. 2, p. 79-85, 1996.

CASTELLANOS-BARLIZA, J.; PELÁEZ, J. D. L. Descomposición de hojarasca y liberación de nutrientes en plantaciones de Acacia mangium establecidas en suelos degradados de Colombia. Revista de Biologia Tropical, San José, v. 59, n. 1, p. 113-128, 2011. 
CASTRO-DÍEZ, P.; FIERRO-BRUNNENMEISTER， N.; GONZÁLEZ-MUÑOZ， N.; GALLARDO, A. Effects of exotic and native tree leaf litter on soil properties of two contrasting sites in the Iberian Peninsula. Plant and Soil, Dordrecht, v. 350, p. 179-191, 2012.

CHAMPMAN, S. K.; KOCH, G. W. What type of diversity yields synergy during mixed litter decomposition in a natural forest ecosystem? Plant and soil, The Hague, v. 299, n. 1-2, p. 153-162, 2007.

CHIGINEVA, N. I.; ALEKSANDROVA, A. V.; MARHAN, S.; KANDELER, E.; TIUNOV, A. V. The importance of mycelia connection at the soil-litter interface for nutrient translocation, enzyme activity and litter decomposition. Applied Soil Ecology, Amsterdam, v. 51, p. 35-41, 2012.

CHRISTINA, M.; LACLAU, J.-P.; GONÇALVES, J. L. M.; JOURDAN, C.; NOUVELLON, Y.; BOUILLET, J.-P. Almost symmetrical vertical growth rates above and below ground in one of the world's most productive forests. Ecosphere, v. 2, n. 3, 2011. Disponível em: <http://www.esajournals.org/doi/pdf/10.1890/ES10-00158.1>. Acesso em: 20 mar. 2012.

COELHO, S. R. F.; GONÇALVES, J. L. M.; MELLO, S. L. M.; MOREIRA, R. M.; SILVA, E. V.; LACLAU, J-P. Crescimento, nutrição e fixação biológica de nitrogênio em plantios mistos de eucalipto e leguminosas arbóreas. Pesquisa Agropecuária Brasileira, Brasília, v. 42, n. 6, p. 759-768, 2007.

COLEMAN, D. C.; CROSSlEY, D. A. J. R.; HENDRIX, P. F. Fundamentals of soil ecology. Burlington: Elsevier Academic Press, 2004. 386 p.

COQ, S.; WEIGEL, J.; BUTENSCHOEN, O.; BONAL, D.; HÄTTENSCHWILER, S. Litter composition rather than plant presence affects decomposition of tropical litter mixtures. Plant and Soil, Dordrecht, v. 343, n. 1-2, p. 273-286, 2011.

CORREIA, M. E. F.; ANDRADE, A. G. Formação de serapilheira e ciclagem de nutrientes. In: SANTOS, G. A. et al. (Eds.). Fundamentos da matéria orgânica do solo. 2. ed. Porto Alegre: Metrópole, 2008. 645 p.

CORTEZ, J.; DEMARD, J. M.; BOTTNER, P.; JACTEUR MONROZIER, L. Decomposition of Mediterranean leaf litter: a microcosm experiment investigating relationships between decomposition rates and litter quality. Soil Biology \& Biochemistry, Oxford, v. 28, n. 4-5, p. 443-452, 1996.

COSTA, G. S.; GAMA-RODRIGAS, A. C.; CUNHA, G. M. Decomposição e liberação de nutrientes da serapilheira foliar em povoamento de Eucalyptus grandis no norte fluminense. Revista Árvore, Viçosa, v. 29, n. 4, p. 563-570, 2005.

DICKOW, K. M. C. Deposição, decomposição e ciclagem de fitomassa e nutrientes da serapilheira, em sucessão secundária na Floresta Atlântica, Antonina (PR). 2010. 234 f. Tese (Doutorado em Engenharia Florestal) - Universidade Federal do Paraná, Curitiba, 2010. 
DJARWANTO; TACHIBANA, S. Decomposition of lignin and holocellulose on Acacia mangium leaves and twings by six fungal isolates from nature. Pakistan Journal of Biological Sciences, v. 13, n. 12, p. 604-610, 2010.

DORNBUSH, M. E.; ISENHART, T. M.; RAICH, J. W. Quantifying fine-root decomposition: an alternative to buried litterbags. Ecology, Washington, v.83, n. 11, p. 29852990, 2002.

DUBOIS, M.; GILLES, K. A.; HAMILTON, J. K.; REBERS, P. A.; SMITH, F. Colorimetric method for determination of sugars and related substances. Analytical Chemistry, Moscow, v. 28, p. 350-356, 1956.

EMBRAPA. Centro Nacional de Pesquisa de Solos. Manual de métodos de análise de solos. Rio de Janeiro: EMBRAPA-CNCS, 1997. 212 p.

EMBRAPA. Sistema brasileiro de classificação de solos. Rio de Janeiro: Embrapa Solos, 1999. $412 \mathrm{p}$.

FAHEY, T. J.; YAVITT, J. B.; SHERMAN, R. E.; GROFFMAN, P. M.; FISK, M. C.; MAERZ, J. C. Transport of carbon and nitrogen between litter and soil organic matter in a northern Hardwood Forest. Ecosystems, New York, v. 14, n. 4, p. 326-340, 2011.

FOOD AND AGRICULTURE ORGANIZATION - FAO. Disponível em: <http://www.fao.org>. Acesso em: 18 maio 2011.

FENILLI, T. A. B.; REICHARDT, K.; BACCHI, O. O. S.; TRIVELIN, P. C. O.; DOURADO-NETO, D. The ${ }^{15} \mathrm{~N}$ isotope to evaluate fertilizer nitrogen absorption efficiency by the coffee plant. Anais da Academia Brasileira de Ciências, Rio de Janeiro, v. 79, n. 4, p. 767-776, 2007.

FREY, S. D.; SIX, J.; ELLIOTT, E. T. Reciprocal transfer of carbon and nitrogen by decomposer fungi at the soil: litter interface. Soil Biology \& Biochemistry, Oxford, v. 35, n. 7, p. 1001-1004, 2003.

FOELKEL, C. O eucalipto e as leguminosas. 2008. Disponível em: < http://www.eucalyptus.com.br/capitulos/PT08_leguminosas.pdf >. Acesso em: 29 abr. 2012.

FORRESTER, D. I.; BAUHUS, J.; COWIE, A. L.; VANCLAY, J. K. Mixed-species Eucalyptus with nitrogen-fixing trees: a review. Forest Ecology and Management, Amsterdam, v. 233, n. 2-3, p. 211-230, 2006.

GARAY, I.; KINDEL, A.; CARNEIRO, R.; FRANCO, A.; BARROS, E.; ABBADIE, L. Comparação da matéria orgânica e de outros atributos do solo entre plantações de Acacia mangium e Eucalyptus grandis. Revista Brasileira de Ciência do Solo, Campinas, v. 27, p. 705-712, 2003.

GARTEN, C. T. J.; IVERSEN, C.; NORBY, R. J. Litterfall ${ }^{15} \mathrm{~N}$ abundance indicates declining soil nitrogen availability in a free-air $\mathrm{CO}_{2}$ enrichment experiment. Ecology, Washington, v. 92, n. 1, p. 133-139, 2011. 
GATTO, A.; BARRO, N. I.; NOVAIS, R. F.; SILVA, I. R.; LEITE, H. G.; LEITE, F. P.; VILLANI, E. M. Estoques de carbono no solo e na biomassa em plantação de eucalipto. Revista Brasileira de Ciência do Solo, Viçosa, v. 34, n. 4, p. 1069-1079, 2010.

GAVA, G. J. C.; TRIVELIN, P. C. O.; VITTI, A. C.; OLIVEIRA, M. W. Recuperação de nitrogênio $\left({ }^{15} \mathrm{~N}\right)$ da uréia e da palhada por soqueira de cana-de-açúcar (Saccharum spp.). Revista Brasileira de Ciência do Solo, Viçosa, v. 27, p. 621-630, 2003

GHOLZ H. O.; WEDIN, D. A.; SMITHERMAN, S. M.; HARMON, M. E.; PARTON, W. J. Long term dynamics of pine and hardwood litter in contrasting environments: toward a global model of decomposition. Global Change Biology, Oxford, v. 6, n. 7, p. 751-765, 2000.

GONÇALVES, J. L. M.; VAN RAIJ, B; GONÇALVES, J. C.; Florestais. In: VAN RAIJ, B.; CANTARELlA, H.; QUAGGIO, J. A.; FURLANI, A. M. C. (Eds.) Recomendações de adubação e calagem para o Estado de São Paulo. Campinas: Instituto Agronômico de Campinas, 1996. p. 245-259.

GONÇALVES, J. L. M.; STAPE, J. L.; LACLA, J-P.; SMETHURST, P.; GAVA, J. L. Silvicultural effects on the productivity and wood quality of eucalypt plantations. Forest Ecology and Management, Amsterdam, v. 193, n. 1-2, p. 45-61, 2004.

GÜSEWELL, S.; FREEMAN, C. Nutrient limitation and enzyme activities during litter decomposition of nine wetland species in relation to litter N:P ratios. Functional Ecology, Oxford, v. 19, n. 4, p. 582-593, 2005.

GÜSEWELL, S.; GESSNER, M. O. N:P ratios influence litter decomposition and colonization by fungi and bacteria in microcosms. Functional Ecology, Oxford, v. 23, n. 1, p. 211-219, 2009.

HAMMEL, K. E. Fungal degradation of lignin. In: GADISH, G.; GILLER, K. E. (Eds.). Driven by nature: plant litter quality and decomposition. Wallingford: CAB International, 1997. p. 33-45.

HARGUiNDEGUY, N. P.; BLUNDO, C. M.; GURVICH, D. E.; DÍAZ, S.; CUEVAS. E. More than the sum of its parts? Assessing litter heterogeneity effects on the decomposition of litter mixtures through leaf chemistry. Plant and Soil, Dordrecht, v. 303, p. 151-159, 2008.

HÄTTENSCHWILLER, S.; VITOUSEK, P. M. The role of polyphenols in terrestrial ecosystem nutrient cycling. Tree, Washington, v.15, n. 6, p. 238-243, 2000.

HÄTTENSCHWILER, S.; TIUNOV, A. V.; SCHEU, S. Biodiversity and litter decomposition in terrestrial ecosystems. Annual Review of Ecology Evolution and Systematics, Palo Alto, v. 36, n. 1, p. 191-218, 2005.

HÄTTENSCHWILER, S.; JORGENSENT, H. B. Carbon quality rather than stoichiometry controls litter decomposition in a tropical rain forest. Journal of Ecology, Oxford v. 98, n. 4, p. 754-763, 2010.

HILLEL, D. Environmental soil physic. San Diego: Academic Press, 1998. 771 p. 
HE, X. N.; CRITCHLEY, C.; BLEDSOE, C. Nitrogen transfer within and between plants through common mycorrhizal networks (CMNs). Reviews in Plant Sciences, Boca Raton, v. 22, n. 6, p. 531-567, 2003.

HE, X.; CRITCHLEY, C.; NG, H.; BLEDSOE, C. Nodulated $\mathrm{N}_{2}$-fixing Casuarina cunninghamiana is the sink for net $\mathrm{N}$ transfer from non- $\mathrm{N}_{2}$-fixing Eucalyptus maculata via an ectomycorrhizal fungus Pisolithus sp. using ${ }^{15} \mathrm{NH}_{4}{ }^{+}$or ${ }^{15} \mathrm{NO}_{3}{ }^{-}$supplied as ammonium nitrate. New Phytologist, Cambridge, v. 167, n. 3, p. 897-912, 2005.

HE, X.; XU, M.; QIU, G. Y.; ZHOU, J. Use of ${ }^{15} \mathrm{~N}$ stable isotope to quantify nitrogen transfer between mycorrhizal plants. Journal of Plant Ecology, Oxford, v. 2, n. 3, p. 107-118, 2009.

HERMANN, W. A.; McGILL, W.B.; DORMMAR, J. F. Effects of initial chemical composition on decomposition of roots of three grass species. Canadian Journal of Soil Science, Ottawa, v. 57, n. 2, p. 205-215, 1977.

HERNÁNDEZ, J.; PINO, A.; SALVO, L.; ARRANTE, G. Nutrient export and harvest residue decomposition patterns of a Eucalyptus dunnii Maiden plantation in temperate climate of Uruguay. Forest Ecology and Management, Amsterdam, v. 258, n. 2, p. 92-99, 2009.

HOBBIE, J. E.; HOBBIE, E. A. ${ }^{15} \mathrm{~N}$ in symbiotic fungi and plants estimates nitrogen and carbon flux rates in Arctic tundra. Ecology, Washington, v.87, n. 4, p. 816-822, 2006.

HÖGBERG, P. Tansley review No 95-N15 natural abundance in soil-plant systems. New Phyologist, London, v. 137, n. 2, p. 179-203, 1997.

JENSEN, E. S. Barley uptake of $\mathrm{N}$ deposited in the rhizosphere of associated field pea. Soil Biology \& Biochemistry, Oxford, v. 28, n. 2, p. 159-162, 1996.

JOHN, M. G. S.; ORWIN, K. H.; DICKIE, I. A. No 'home' versus 'away' effects of decomposition found in a grassland-forest reciprocal litter transplant study. Soil Biology \& Biochemistry, Oxford, v. 43, n. 7, p. 1482-1489, 2011.

JUNK, G.; SVEC, H. V. The absolute abundance of the nitrogen isotopes in the atmosphere and compressed gas from various sources. Geochimica et Cosmochimica Acta, London, v. 14, n. 3, p. 234-243, 1958.

KHANNA, P. K. Nutrient cycling under mixed-species tree systems in southeast Asia. Agroforestry Systems, Dordrecht, v. 38, n. 1-3, p. 99-120, 1998.

KOLM, L.; POGGIANI, F. Ciclagem de nutrientes em povoamentos de Eucalyptus grandis submetidos à prática de desbastes progressivos. Scientia Forestalis, Piracicaba, n. 63, p. 7983, 2003.

KUPERMAN, R. G. Litter decomposition and nutrient dynamics in oak-hickory Forest along a historic gradiente of nitrogen and sulfur deposition. Soil Biology and Biochemistry, Oxford,v. 31, n. 2, p. 237-244, 1999. 
LACLAU, J. P.; RANGER, L.; DELEPORTE, P.; NOUVELLON, Y.; SAINT-ANDRÉ, L.; MARLET, S.; BOUILLET, J. P. Nutrient cycling in a clonal stand of Eucalyptus and an adjacent savanna ecosystem in Congo. 3. Input-output budgets and consequences for the sustainability of the plantations. Forest Ecology and Management, Amsterdam, v. 210, n. 13, p. 375-391, 2005.

LACLAU, J. P.; BOUILLET, J. P.; GONÇALVES, J. L. M.; SILVA, E. V.; JOURDAN, C.; CUNHA, M. C. S.; MOREIRA, M. R.; SAINT-ANDRÉ, L.; MAQUÈRE, V.; NOUVELLON, Y.; RANGER, J. Mixed-species plantation of Acacia mangium and Eucalyptus grandis in Brazil 1. Growth dynamics and aboveground net primary production. Forest Ecology and Management, Amsterdam, v. 255, n. 12, p. 3905-3917, 2008.

LACLAU, J. P.; RANGER, J.; GONÇALVES, J. L. M.; MAQUÈRE, V.; KRUSCHE, A.V.; BOU, A. T; NOUVELLON, Y.; SAINT-ANDRÉ, L.; BOUILLET, J. P.; PICCOLO, M. C.; DELEPORTE, P. Biogeochemical cycles of nutrients in tropical Eucalyptus plantation: Main features shown by intensive monitoring in Congo and Brazil. Forest Ecology and Management, Amsterdam, v. 259, n. 9, p. 1771-1785, 2010.

LEÃO, M. R. A floresta e o homem. São Paulo: EDUSP, 2000. 448 p.

LEMMA, B.; NILSSON, I.; KLEJA, D. B.; OLSSON, M.; KNICKER, H. Decomposition and substrates quality of leaf litters and fine roots from three exotic plantation and a native forest in the southwestern highlands of Ethiopia. Soil Biology \& Biochemistry, v. 39, n. 9, p. 2317 2328, 2007.

LEVEAU, J. Life on leaves. Nature, London, v. 461, n. 7265, p. 741, 2009.

LI, Z.; PENG, S.; RAE, D. J.; ZHOU, G. Litter decomposition and nitrogen mineralization of soils in subtropical plantation forests of southern China, with special attention to comparisons between legumes and non-legumes. Plant and Soil, Dordrecht, v. 229, p. 105-116, 2001.

LIN, C.; YANG, Y.; GUO, J.; CHEN, G.; XIE, J. Fine root decomposition of evergreen broadleaved and coniferous tree species in mid-subtropical China: dynamics of dry mass, nutrient and organic fractions. Plant and Soil, Dordrecht, v. 229, p. 105-116, 2001.

LOPES, E. S. Fixação biológica do nitrogênio no sistema solo-planta. In: YAMADA, T.; ABDALLA, S. R. S.; VITTI, G. C. (Eds.). Nitrogênio e enxofre na agricultura brasileira. Piracicaba: IPNI Brasil, 2007. 722 p.

LOUZADA, J. N. C.; SCHOEREDER, J. H.; DE MARCO, P. J. Litter decomposition, semideciduous forest and Eucalyptus spp.: crop in Brazil; a comparison. Forest Ecology and Management, Amsterdam, v. 94, n. 1-3, p. 31-36, 1997.

MACEDO, R. L. G.; VALE, A. B.; VENTURIN, N. Eucalipto em sistemas florestais. Lavras: Editora UFLA, 2010. 331 p.

MAISTO, G. MARCO, A.; MEOLA, A.; SESSA, L.; SANTO, A. V. Nutrient dynamics in litter mixtures of four Mediterranean maquis species decomposing in situ. Soil Biology \& Biochemistry, Oxford, v. 43, n. 3, p. 520-530, 2011. 
MAKKAR, H. P. S.; BLUMMEL M.; BOROWY, N. K.; BECKER, K. Gravimetric determination of tannins and their correlation with chemical and protein precipitation methods. Journal of the Science of Food and Agriculture, London, v. 61, p. 161-165, 1993.

MALAVOLTA, E.; VITTI, G.C.; OLIVEIRA, S.A. de. Avaliação do estado nutricional das plantas: princípios e aplicações. Piracicaba: Associação Brasileira para Pesquisa da Potassa e do Fosfato, 1989. 201p.

MARSHALL, J. D.; BROOKS, R.; LAJTHA, K. Source of variation in the stable isotopic composition of plants. In: MICHENER, R.; LAJTHA, K. (Eds.). Stable isotopes in ecology and environment science (ecological methods and concepts). Oxford: Wiley-Blackwell, 2007. $592 \mathrm{p}$.

MARTINS, S. C. Caracterização dos solos e serapilheira ao longo do gradiente altitudinal da Mata Atlântica, estado de São Paulo. 2010. 155 f. Tese (Doutorado em Ciências) - Centro de Energia Nuclear na Agricultura, Universidade de São Paulo, Piracicaba, 2010.

MELILLO, J. M.; ABER, J. D.; LINKENS, A. E.; RICCA, A.; FRY, B.; NADELHOFFER, $\mathrm{K}$. Carbon and nitrogen dynamics along the decay continuum: plant litter to soil organic matter. In: CLARHOLM, M.; BERGSTRON, L. (Eds.). Ecology of arable lands. Dordrecht: Kluwer Academic Press, 1989. p.53-62.

MELLO, S. L. M.; GONÇALVES, J. L. M.; GAVA, J. L. Pre and post harvest fine root growth in E. grandis stands installed in sandy and loamy soils. Forest Ecology and Management, Amsterdam, v. 246, n. 2-3, p. 186-1985, 2007.

MOORHEAD, D. L.; CURRIE, W. S.; RASTTETTER, E. B.; PARTON, W. J.; HARMON, M. E. Climate and litter quality controls on decomposition: an analysis of modeling approaches. Global Biogeochemical Cycles, Washington, v. 13, p. 575-589, 1999.

MORA, A. L.; GARCIA, C. H. A cultura do eucalipto no Brasil. São Paulo: SBS, 2000. $112 \mathrm{p}$.

MOREIRA, F. M. S.; SIQUEIRA, J. O. Microbiologia e bioquímica do solo. Lavras: Editora UFLA, 2006. 729 p.

MOTTA, P. E. F.; CURI, N.; SIQUEIRA, J. O.; VAN RAIJ, B.; FURTINI NETO, A. E.; LIMA, J. M. Adsorção e formas de fósforo em latossolos: influências da mineralogia e histórico de uso. Revista Brasileira de Ciência do Solo, Viçosa, v. 26, n. 2, p. 349-359, 2002.

NEVES, M. C. P.; Como os microrganismos do solo obtêm energia e nutrientes. In: CARDOSO, E. J. B. N.; TSAI, S. M.; NEVES, M. C. P. (Org.). Microbiologia do solo. Campinas: SBCS, 1992, 360 p.

NGAO, J.; BERNHARD-REVERSAT, F.; LOUMETO, J-J. Changes in eucalypt litter quality during the first three months of field decomposition in a Congolese plantation. Applied Soil Ecology, Amsterdam, v. 42, n. 3, p. 191-199, 2009. 
NOVAIS, R. F.; SMYTH, T. J.; NUNES, F. N. Fósforo. In: NOVAIS, R. F.; ALVAREZ, V. H.; BARROS, N. F.; FONTES, R. L. F.; CANTARUTTI, R. B.; NEVES, J. C. L. Fertilidade do solo. Viçosa: SBCS, 2007. p. 471-537.

O'CONNELL, A. M.; GROVE, T. S. Biomass production nutrient uptake and nutrient cycling in the Jarrah (Eucalyptus marginata) and Karri (Eucalyptus diversicolor) forests of SouthWestern Australia. In: ATTIWILL, P. M.; MARK, A. A. (Eds.). Nutrition of eucalypts. Melborne: CSIRO, 1996. p. 155-189.

ORSBORNE, J. L.; MacULEY, B.J. Decomposition of Eucalyptus leaf litter: influence of seasonal variation in temperature and moisture conditions. Soil Biology \& Biochemistry, Oxford, v. 20, n. 3, p. 369-375, 1988.

PARTEY, S. T.; QUASHIE-SAM, S. J.; THEVATHASAN, N. V.; GORDON, A. M. Decomposition and nutrient release patterns of the leaf biomass of the wild sunflower (Tithonia diversifolia): a comparative study with four leguminous agroforestry species. Agroforestry Systems, Dordrecht, v. 81, n. 2, p. 123-134, 2011.

PAUL, E. A.; CLARK, F. E. Soil microbiology and biochemistry. San Diego: Academic Press, 1996. 340 p.

PAVEI, M. A. Decomposição de resíduos culturais e emissão de gases do efeito estufa em sistemas de manejo do solo em Ponta Grossa (PR). 2005. 114 f. Dissertação (Mestrado em Ecologia de Agrossistemas) - Escola Superior de Agricultura Luiz de Queiroz, Universidade de São Paulo, Piracicaba, 2005.

PÉREZ-SUÁREZ, M.; ARREDONDO-MORENO, J. T.; HUBER-SANNWALD, E. Early stage of single and mixed leaf-litter decomposition in semiarid Forest pine-oak: the role of rainfall and microsite. Biogeochemistry, Dordrecht, v. 108, n. 1-3, p. 245-258, 2012.

PICCOLO, M. C.; NEIL, C.; MELILlO, J. M.; CERRI, C. C.; STEUDLER, P. A. 15N natural abundance in Forest and pasture soils of the Brazilian Amazon Basin. Plant and Soil, Dordrecht, v. 182, n. 2, p. 249-258, 1996.

PRESCOTT, C. E. Litter decomposition: what controls it and how can we alter it to sequester more carbon in forest soils? Biogeochemistry, Dordrecht, v. 101, n. 1-3, p. 133-149, 2010.

PORTER, L. J.; HRSTICH, L. N.; CHAN, B. G. The conversion of procyanidins and prodelphinidins to cyanidin and delphinidin. Phytochemistry, New York, v. 25, n. 1, p. 223230, 1986.

RACHID, C. T. C. C. Comunidade bacteriana, atributos do solo e fluxo de gases em solo sob Cerrado e cana-de-açúcar. 2010. 126 f. Dissertação (Mestrado em Ciências) - Centro de Energia Nuclear na Agricultura, Universidade de São Paulo, Piracicaba, 2010.

SAlAS, A. M.; ElliOT, E. T.; WESTFAlL, D. G.; COLE, C. V.; SIX, J. The role of particulate organic matter in phosphorus cycling. Soil Science Society of America Journal, Madison, v. 67, n. 1, p. 181-189, 2003. 
SAMAULLAH, M.; CHABBI, A.; LEIFELD, J.; BARDOUX, G.; BILLOU, D.; RUMPEL, C. Decomposition and stabilization of root litter in top- and subsoil horizons: what is the difference? Plant and Soil, Dordrecht, v. 338, n. 1-2, p. 127-141, 2011.

SCHIMEL, J. P.; BENNET, J. Nitrogen mineralization: challenges of a chancing paradigm. Ecology, Washington, v. 85, n. 3, p. 591-602, 2004.

SCHIMEL, J. P.; HÄTTENSCHWILER, S. Nitrogen transfer between decomposing leaves of different N status. Soil Biology \& Biochemistry, Oxford, v. 39, n. 7, p. 1428-1436, 2007.

SCHWENDENER, C. M.; LEHMANN, J.; CAMARGO, P. B.; LUIZÃO, R. C. C; FERNANDES, E.C.M. Nitrogen transfer between high- and low-quality leaves on a nutrientpoor Oxisol determined by ${ }^{15} \mathrm{~N}$ enrichment. Soil Biology \& Biochemistry, Oxford, v. 37, n. 4, p. 787-794, 2005.

SERVIÇO FLORESTAL BRASILEIRO. Florestas do Brasil em resumo - 2010: dados de 2005-2010. Brasília: SFB, 2010. 152 p.

SHEARE, G.; KOHL, D. H. $\mathrm{N}_{2}$-fixation in field settings: estimations based on natural $15 \mathrm{~N}$ abundance. Australian Journal of Plant Physiology, Collingwood, v. 13, n. 6, p. 699-756, 1986.

SIERRA, J.; DAUDIN, D.; DOMENACH, A. M.; NYGREN, P.; DESFONTAINES, L.; SILVA, J C. Nitrogen transfer from a legume tree to the associated grass estimated by the isotopic signature of tree root exudates: A comparison of the ${ }^{15} \mathrm{~N}$ leaf feeding and natural ${ }^{15} \mathrm{~N}$ abundance methods. European Journal of Agronomy, Amsterdam, v. 27, n. 2-4, p. 178-186, 2007.

SILVA, J. C. Paradigmas das plantações de eucalipto: no limiar entre o bom senso e a insensatez. Viçosa: Arka, 2009. 128 p.

SIQUEIRA, J. O.; FRANCO, A. A. Biotecnologia do solo: fundamentos e perspectivas. Brasília: Ministério da Educação e Cultura, 1988. 236 p.

SOCIEDADE BRASILEIRA DE SILVICULTURA. Fatos e números do Brasil florestal. 2008. Disponível em: 〈http://www.sbs.org.br/FatoseNumerosdoBrasilFlorestal.pdf>. Acesso em: 26 de jun. 2011.

SWIFT, M. J.; HEAL, O. W.; ANDERSON, J. M. Decomposition in terrestrial ecosystems. Oxford: Blackell Scientific, 1979. 372 p.

TALBOLT, J. M.; YELLE, D. J,; NOWICK, J.; TRESEDER, K. K. Litter decay are determined by lignin chemistry. Biogeochemistry, Dordrecht, v. 108, n. 1-3, p. 279-295, 2011.

TALBOLT, J. M.; TRESEDER, K. K. Interactions among lignin, cellulose, and nitrogen drive litter chemistry-decay raltionship. Ecology, Oxford, v. 93, n. 2, p. 345-354, 2012. 
TRIVELIN, P. C. O.; SALATI, E.; MATSUI, E. Preparo de amostras para análise de ${ }^{\mathbf{1 5}} \mathbf{N}$ por espectrometria de massas. Piracicaba: CENA/USP, 1973. 41 p. (Cena. Boletim Técnico, 2).

TRIVELIN, P. C. O.; BENDASSOLI, J. A.; OlIVEIRA, M. W.; MURAOK, T. Potencialidade da mistura da aquamônia com vinhaça na fertilização de canaviais colhidos sem despalha a fogo. Parte II. Perdas por volatilização da amônia e recuperação do ${ }^{15} \mathrm{~N}$ aplicado ao solo. STAB - Açúcar, Álcool e Subprodutos, Piracicaba, v. 16, n. 3, p. 23-26, 1998.

TRIVELIN, P. C. O.; OLIVEIRA, M. W.; VITTI, A. C.; GAVA, G. J. L.; BENDASSOLI, J. A. Perdas de nitrogênio as ureia no sistema solo-planta em dois ciclos de cana-de-açúcar. Pesquisa Agropecuária Brasileira, Brasília, v. 37, n. 2, p. 193-201, 2002.

VALENZUELA-SOLANO, C.; CROHN, D. M. Are decomposition and N release from organic mulches determined mainly by their chemical composition? Biology \& Biochemistry, Oxford, v. 38, n. 2, p. 377-384, 2006.

VAN RAIJ, B.; ANDRADE, J. C.; CANTARELLA, H.; QUAGGIO, J. A. Análise química para avaliação da fertilidade de solos tropicais. Campinas: Instituto Agronômico, 2001, $285 \mathrm{p}$.

VAN SOEST, P. J. Symposium on nutrition and forage and pastures new chemical procedures for evaluating forages. Journal of Animal Science, Albany, v. 23, n. 3, p. 838-845, 1964.

VEZZANI, F. M.; TEDESCO, M. J.; BARROS, N. F. Alterações dos nutrientes no solo e nas plantas em consórcio de eucalipto e acácia negra. Revista Brasileira de Ciência do Solo, Viçosa, v. 25, n. 1, p. 225-231, 2001.

VIERA, M.; SCHUMACHER, M. V.; LIBERALESSO, E. Crescimento e produtividade de povoamentos monoespecíficos e mistos de eucalipto e acácia-negra. Pesquisa Agropecuária Tropical, Goiânia, v. 41, n. 3, p. 415-421, 2011.

VIVANCO, L.; AUSTIN, A. T. Intrinsic effects of species on leaf litter and root decomposition: a comparison of temperate grasses from North and South America. Oecologia, Berlin, v. 150, n. 1, p. 97-107, 2006.

VIVANDO, L; AUSTIN, A. T. Tree species identity alters forest litter decomposition through long-term plant and soil interactions in Patagonia, Argentina. Journal of Ecology, Oxford, v. 96, p. 727-736, 2008.

VIVANDO, L; AUSTIN, A. T. Nitrogen addition stimulates Forest litter decomposition and disrupts species interactions in Patagonia, Argentina. Global Changes Biology, Oxford, v. 17, p. 1963-1974, 2011.

VOIGTLAENDER, M.; LACLAU, J. P.; GONÇALVES, J. L. M.; PICCOLO, M. C.; MOREIRA, M.; NOUVELLON, Y.; RANGER, J.; BOUILLET, J. P. Introducing Acacia mangium trees in Eucalyptus grandis plantations: consequences for soil organic matter stocks and nitrogen mineralization. Plant and Soil, Dordrecht, v. 347, p. 1-13, 2011. 
WAKSMAN, S. A.; STARKEY, R. L. Influence of organic matter upon the development of fungi, actinomycetes and bacterial in the soil. Soil Science, v. 17, n. 3, p. 374-378, 1924.

WALLENDER, H.; JOHANSSON, J.; PALLON, J. PIXEL analysis to estimate the elemental composition of ectomycorrhizal rhizomorphs grown in contact with different minerals in forest soil. FEMS Microbiology Ecology, Amsterdam, v. 9, n. 2, p. 147-156, 2002.

WARDLE, D. A.; WALKER, L. R.; BARDGETT, R. D. Ecosystem properties and forest decline in contrasting long-term chronosequences. Science, Washington, v. 305, n. 5683, p. 509-513, 2004.

WANG, H.; LIU, S.; MO, J. Correlation between leaf litter and fine root ecompositionamong subtropical tree species. Plant and Soil, The Hague, v. 335, n. 1-2, p. 289-298, 2010.

WANG, F. M.; LI, Z. A.; XIA, H. P.; ZOU, B.; LI, N. Y.; LIU, J.; ZHU, W. X Effects of nitrogen-fixing and non-nitrogen-fixing tree species on soil properties and nitrogen transformation during forest restoration in southern China. Soil Science and Plant Nutrition, Tokyo, v. 56, n. 2, p. 297-306, 2010.

XIANG, W.; BAUHUS, J.; Does the addition of litter from N-fixing Acacia mearnsii accelerate leaf decomposition of Eucalyptus globulus? Australian Journal of Botany, Melbourne, v. 55, n. 5, p. 576-583, 2007.

XIONG, Y.; XIA, H.; LI, ZHI'AN.; CAI, XI'AN.; FU, S. Impacts of litter and understory removal on soil properties in a subtropical Acacia mangium plantation on China. Plant and Soil, The Hague, v. 304, n. 1-2, p. 179-188, 2008.

ZELLER, B.; COLIN-BELGRAND, M.; DAMBRINE, E.; MARTIN, F.; BOTTNER, P. Decomposition of ${ }^{15} \mathrm{~N}$-labelled beech litter and fate of nitrogen derived from litter in a beech forest. Oecologia, Berlin, v. 123, n. 4, p. 550-559, 2000.

ZELLER, B.; COLIN-BELGRAND, M.; DAMBRINE, E.; MARTIN, F. Fate of nitrogen released from ${ }^{15} \mathrm{~N}$-labeled litter in European beech forests. Tree Physiology, Oxford v. 21, n. 2-3, p.153-163, 2001.

ZHANG, W.; WANG, S. Effects of $\mathrm{NH}_{4}{ }^{+}$and $\mathrm{NO}_{3}{ }^{-}$on litter and soil organic carbon decomposition in a Chinese fir plantation forest in South China. Soil Biology \& Biochemistry, Oxford, v. 47, n. 7, p. 116-122, 2012. 
ANEXOS 
Anexo A - Porcentagem de massa remanescente das folhas e raízes ${ }^{(1)}$ de E. grandis e A. mangium nas condições plantio de eucalipto (E), plantio de acácia na primeira rotação (1R) e plantio de acácia na segunda rotação $(2 \mathrm{R})$ durante o experimento de decomposição ${ }^{(2)}$. Os valores representam a média $(n=9) \pm$ desvio padrão $^{(3)}$

\begin{tabular}{|c|c|c|c|c|c|}
\hline \multicolumn{2}{|l|}{ Tipo de material } & \multicolumn{4}{|c|}{ Massa remanescente $(\%)$} \\
\hline Folhas & Condição & 92 dias & 181 dias & 275 dias & 367 dias \\
\hline A. mangium & $\mathrm{E}^{3}$ & $88,81 \pm 4,26 \mathbf{a}$ & $88,81 \pm 4,26 \mathbf{a}$ & $76,03 \pm 8,39$ abc & $81,21 \pm 10,21 \mathbf{a}$ \\
\hline A. mangium & $1 \mathrm{R}$ & $91,24 \pm 7,83 \mathbf{a}$ & $91,24 \pm 7,83 \mathbf{a}$ & $84,87 \pm 6,36 \mathbf{a}$ & $75,69 \pm 10,87 \mathbf{a}$ \\
\hline A. mangium & $2 \mathrm{R}$ & $89,99 \pm 5,35 \mathbf{a}$ & $89,99 \pm 5,35 \mathbf{a}$ & $77,01 \pm 8,34 \mathbf{a b}$ & $72,88 \pm 10,53 \mathbf{a b}$ \\
\hline E. grandis & $\mathrm{E}$ & $72,09 \pm 5,93 \mathbf{b}$ & $65,06 \pm 9,27 \mathbf{b}$ & $65,52 \pm 9,27 \mathbf{b c}$ & $61,82 \pm 11,44 \mathbf{b c}$ \\
\hline E. grandis & $1 \mathrm{R}$ & $74,67 \pm 7,27 \mathbf{b}$ & $62,23 \pm 16,59 \mathbf{b}$ & $64,35 \pm 8,43 \mathbf{c}$ & $60,66 \pm 12,00 \mathbf{b c}$ \\
\hline E. grandis & $2 \mathrm{R}$ & $74,12 \pm 7,42 \mathbf{b}$ & $61,74 \pm 7,33 \mathbf{b}$ & $66,01 \pm 9,12$ bc & $56,75 \pm 10,53 \mathbf{c}$ \\
\hline Raízes & Condição & 92 dias & 181 dias & 275 dias & 367 dias \\
\hline A. mangium & $\mathrm{E}^{3}$ & $67,81 \pm 7,38 \mathbf{a}$ & $67,81 \pm 7,38 \mathbf{a}$ & $52,70 \pm 8,65 \mathbf{a b}$ & $62,50 \pm 8,97 \mathbf{a}$ \\
\hline A. mangium & $1 \mathrm{R}$ & $66,28 \pm 12,24 \mathbf{a}$ & $66,33 \pm 10,21 \mathbf{a}$ & $52,21 \pm 9,84 \mathbf{a b}$ & $56,83 \pm 8,04 \mathbf{a b}$ \\
\hline A. mangium & $2 \mathrm{R}$ & $62,51 \pm 12,72 \mathbf{a}$ & $71,27 \pm 9,25 \mathbf{a}$ & $57,97 \pm 9,25 \mathbf{a}$ & $54,35 \pm 12,40 \mathbf{a b}$ \\
\hline E. grandis & $\mathrm{E}$ & $70,24 \pm 6,13 \mathbf{a}$ & $63,23 \pm 7,30 \mathbf{a}$ & $39,89 \pm 10,22 \mathbf{b}$ & $48,99 \pm 16,86 \mathbf{a b}$ \\
\hline E. grandis & $1 \mathrm{R}$ & $72,75 \pm 5,94 \mathbf{a}$ & $66,71 \pm 7,65 \mathbf{a}$ & $46,00 \pm 11,15 \mathbf{a b}$ & $41,92 \pm 13,46 \mathbf{b}$ \\
\hline E. grandis & $2 \mathrm{R}$ & $71,99 \pm 5,12 \mathbf{a}$ & $64,05 \pm 8,12 \mathbf{a}$ & $43,73 \pm 11,19 \mathbf{b}$ & $44,07 \pm 9,27 \mathbf{a b}$ \\
\hline
\end{tabular}

(1) Folhas e raízes foram comparadas separadamente.

(2) As datas foram comparadas separadamente.

(3) Médias seguidas da mesma letra nas colunas não diferem estatisticamente pelo teste de Tukey a 5\% de probabilidade. 
Anexo B - Massa (g) das folhas e raízes ${ }^{(1)}$ de E. grandis e A. mangium nas condições plantio de eucalipto (E), plantio de acácia na primeira rotação $(1 \mathrm{R})$ e plantio de acácia na segunda rotação $(2 \mathrm{R})$ durante o experimento de decomposição ${ }^{(2)}$. Os valores representam a média $(\mathrm{n}=9) \pm$ desvio padrão ${ }^{(3)}$

\begin{tabular}{|c|c|c|c|c|c|c|}
\hline Tipo de material & & & & Massa ( & & \\
\hline Folhas & Condição & 0 dias & 92 dias & 181 dias & 275 dias & 367 dias \\
\hline A. mangium & $\mathrm{E}^{3}$ & $10,06 \pm 0,31 \mathbf{a}$ & $7,27 \pm 0,51 \mathbf{a}$ & $6,51 \pm 0,88 \mathbf{a}$ & $6,14 \pm 0,77 \mathbf{a b c}$ & $6,59 \pm 0,86 \mathbf{a}$ \\
\hline A. mangium & $1 \mathrm{R}$ & $10,02 \pm 0,37 \mathbf{a}$ & $7,42 \pm 0,77 \mathbf{a}$ & $6,19 \pm 0,74 \mathbf{a}$ & $7,01 \pm 0,40 \mathbf{a}$ & $6,03 \pm 0,95 \mathbf{a}$ \\
\hline A. mangium & $2 \mathrm{R}$ & $9,72 \pm 0,45 \mathbf{a}$ & $7,45 \pm 0,61 \mathbf{a}$ & $6,71 \pm 0,60 \mathbf{a}$ & $6,33 \pm 1,01 \mathbf{a b}$ & $5,97 \pm 0,56 \mathbf{a b}$ \\
\hline E. grandis & $\mathrm{E}$ & $9,98 \pm 0,45 \mathbf{a}$ & $6,03 \pm 0,32 \mathbf{b}$ & $5,32 \pm 0,57 \mathbf{b}$ & $5,40 \pm 0,78 \mathbf{b c}$ & $5,04 \pm 0,92 \mathbf{b c}$ \\
\hline E. grandis & $1 \mathrm{R}$ & $9,80 \pm 0,31 \mathbf{a}$ & $6,36 \pm 0,32 \mathbf{b}$ & $5,13 \pm 0,47 \mathbf{b}$ & $5,28 \pm 0,69 \mathbf{c}$ & $4,95 \pm 0,99 \mathbf{b c}$ \\
\hline E. grandis & $2 \mathrm{R}$ & $9,84 \pm 0,29 \mathbf{a}$ & $6,75 \pm 0,52 \mathbf{b}$ & $5,07 \pm 0,66 \mathbf{b}$ & $5,45 \pm 0,78 \mathbf{b c}$ & $4,69 \pm 0,85 \mathrm{c}$ \\
\hline Raízes & Condição & 0 dias & 92 dias & 181 dias & 275 dias & 367 dias \\
\hline A. mangium & $E^{3}$ & $7,08 \pm 0,33 \mathbf{a}$ & $3,57 \pm 0,34 \mathbf{a}$ & $2,35 \pm 0,33 \mathbf{a}$ & $2,71 \pm 0,50 \mathbf{a b}$ & $3,29 \pm 0,86 \mathbf{a}$ \\
\hline A. mangium & $1 \mathrm{R}$ & $6,93 \pm 0,28 \mathbf{a}$ & $3,44 \pm 0,30 \mathbf{a}$ & $2,87 \pm 0,38 \mathbf{a}$ & $2,63 \pm 0,56 \mathbf{a b}$ & $2,94 \pm 0,71 \mathbf{a b}$ \\
\hline A. mangium & $2 \mathrm{R}$ & $7,03 \pm 0,29 \mathbf{a}$ & $3,29 \pm 0,32 \mathbf{a}$ & $3,20 \pm 0,36 \mathbf{a}$ & $3,07 \pm 0,58 \mathbf{a}$ & $2,77 \pm 0,51 \mathbf{a b}$ \\
\hline E. grandis & $\mathrm{E}$ & $6,99 \pm 0,33 \mathbf{a}$ & $3,63 \pm 0,35 \mathbf{a}$ & $2,59 \pm 0,95 \mathbf{a}$ & $2,08 \pm 0,48 \mathbf{b}$ & $2,56 \pm 0,54 \mathbf{a b}$ \\
\hline E. grandis & $1 \mathrm{R}$ & $7,01 \pm 0,32 \mathbf{a}$ & $3,77 \pm 0,62 \mathbf{a}$ & $2,84 \pm 0,46 \mathbf{a}$ & $2,36 \pm 0,49 \mathbf{a b}$ & $2,13 \pm 0,40 \mathbf{b}$ \\
\hline E. grandis & $2 \mathrm{R}$ & $7,05 \pm 0,18 \mathbf{a}$ & $3,76 \pm 0,65 \mathbf{a}$ & $2,76 \pm 0,42 \mathbf{a}$ & $2,25 \pm 0,56 \mathbf{b}$ & $2,35 \pm 0,60 \mathbf{a b}$ \\
\hline
\end{tabular}

(1) Folhas e raízes foram comparadas separadamente.

(2) As datas foram comparadas separadamente.

(3) Médias seguidas da mesma letra nas colunas não diferem estatisticamente pelo teste de Tukey a 5\% de probabilidade. 
Anexo C - Composição de compostos orgânicos do material vegetal no início ( $\mathrm{t}=0$ dia) do experimento de decomposição ${ }^{(1)}$. Os resultados representam a média $(n=5) \pm$ desvio padrão ${ }^{(2)}$ Tratamentos

\begin{tabular}{|c|c|c|}
\hline & Lignina $\left(\mathrm{g} \mathrm{kg}^{-1}\right)$ & Celulose $\left(\mathrm{g} \mathrm{kg}^{-1}\right)$ \\
\hline Folha Acácia & $367,67 \pm 24,92 \mathbf{a}$ & $217,86 \pm 22,87 \mathbf{a}$ \\
\hline Folha Eucalipto & $195,78 \pm 9,14 \mathbf{b}$ & $218,50 \pm 10,79 \mathbf{a}$ \\
\hline Raiz Acácia & $292,33 \pm 24,49 \mathbf{a}$ & $306,95 \pm 16,78 \mathbf{b}$ \\
\hline \multirow[t]{2}{*}{ Raiz Eucalipto } & $295,87 \pm 8,82 \mathbf{a}$ & $392,72 \pm 13,21 \mathbf{a}$ \\
\hline & Hemicelulose ( $\left.\mathrm{g} \mathrm{kg}^{-1}\right)$ & Outros fenóis ( $\mathrm{g} \mathrm{kg}^{-1}$ ) \\
\hline Folha Acácia & $137,07 \pm 7,68 \mathbf{a}$ & $24,66 \pm 4,46 \mathbf{a}$ \\
\hline Folha Eucalipto & $86,58 \pm 13,55 \mathbf{b}$ & $17,27 \pm 0,60 \mathbf{b}$ \\
\hline Raiz Acácia & $114,34 \pm 6,40 \mathbf{a}$ & $3,56 \pm 0,60 \mathbf{b}$ \\
\hline \multirow[t]{2}{*}{ Raiz Eucalipto } & $84,90 \pm 17,61 \mathbf{b}$ & $28,19 \pm 0,60 \mathbf{a}$ \\
\hline & Carboidratos solúveis ( $\mathrm{g} \mathrm{kg}^{-1}$ ) & Taninos totais $\left(\mathrm{g} \mathrm{kg}^{-1}\right)$ \\
\hline Folha Acácia & $111,51 \pm 20,87 \mathbf{b}$ & $21,86 \pm 2,19 \mathbf{a}$ \\
\hline Folha Eucalipto & $161,78 \pm 12,92 \mathbf{a}$ & $7,87 \pm 2,84 \mathbf{b}$ \\
\hline Raiz Acácia & $80,28 \pm 7,04 \mathbf{b}$ & $21,53 \pm 3,03 \mathbf{b}$ \\
\hline \multirow[t]{2}{*}{ Raiz Eucalipto } & $155,49 \pm 15,55 \mathbf{a}$ & $78,60 \pm 5,50 \mathbf{a}$ \\
\hline & Taninos condensados $\left(\mathrm{g} \mathrm{kg}^{-1}\right)$ & \\
\hline Folha Acácia & $12,10 \pm 2,09 \mathbf{a}$ & \\
\hline Folha Eucalipto & $3,85 \pm 1,52 \mathbf{b}$ & \\
\hline Raiz Acácia & $9,85 \pm 2,16 \mathbf{a}$ & \\
\hline Raiz Eucalipto & $46,48 \pm 5,45 \mathbf{b}$ & \\
\hline
\end{tabular}


Anexo D - Composição de compostos orgânicos das folhas de E. grandis e A. mangium no final do experimento de decomposição $(\mathrm{t}=367$ dias $)$ nos tratamentos folha FAE, FA1R, FA2R, FEE, FE1R e FE2R. Os resultados representam a média $(n=3) \pm$ desvio padrão ${ }^{(1)}$

\begin{tabular}{|c|c|c|}
\hline \multicolumn{3}{|c|}{ Tratamentos } \\
\hline & Lignina $\left(\mathrm{g} \mathrm{kg}^{-1}\right)$ & Celulose $\left(\mathrm{g} \mathrm{kg}^{-1}\right)$ \\
\hline FAE & $341,65 \pm 32,37 \mathbf{a}$ & $137,23 \pm 16,57 \mathbf{b}$ \\
\hline FA1R & $357,68 \pm 32,33 \mathbf{a}$ & $133,53 \pm 4,59 \mathbf{b}$ \\
\hline FA2R & $367,56 \pm 31,17 \mathbf{a}$ & $145,06 \pm 6,81 \mathbf{b}$ \\
\hline FEE & $197,89 \pm 36,54 \mathbf{b}$ & $129,44 \pm 16,56 \mathbf{b}$ \\
\hline FE1R & $205,49 \pm 16,65 \mathbf{b}$ & $151,66 \pm 19,83 \mathbf{b}$ \\
\hline \multirow[t]{2}{*}{ FE2R } & $209,02 \pm 18,62 \mathbf{b}$ & $184,79 \pm 4,64 \mathbf{a}$ \\
\hline & Hemicelulose $\left(\mathrm{g} \mathrm{kg}^{-1}\right)$ & Outros fenóis $\left(\mathrm{g} \mathrm{kg}^{-1}\right)$ \\
\hline FAE & $108,20 \pm 10,59 \mathbf{a}$ & $6,54 \pm 2,12 \mathbf{a}$ \\
\hline FA1R & $106,52 \pm 7,19 \mathbf{a}$ & $6,55 \pm 3,35 \mathbf{a}$ \\
\hline FA2R & $105,50 \pm 4,53 \mathbf{a}$ & $6,68 \pm 3,35 \mathbf{a}$ \\
\hline FEE & $106,57 \pm 9,31 \mathbf{a}$ & $3,57 \pm 0,11 \mathbf{a}$ \\
\hline FE1R & $102,18 \pm 22,34 \mathbf{a}$ & $4,14 \pm 2,59 \mathbf{a}$ \\
\hline \multirow[t]{2}{*}{ FE2R } & $86,01 \pm 15,74 \mathbf{a}$ & $6,07 \pm 2,59 \mathbf{a}$ \\
\hline & Carboidratos solúveis $\left(\mathrm{g} \mathrm{kg}^{-1}\right)$ & Taninos totais $\left(\mathrm{g} \mathrm{kg}^{-1}\right)$ \\
\hline FAE & $32,13 \pm 1,54 \mathbf{b}$ & $11,50 \pm 2,56 \mathbf{a}$ \\
\hline FA1R & $52,99 \pm 18,36 \mathbf{a}$ & $12,32 \pm 5,28 \mathbf{a}$ \\
\hline FA2R & $41,05 \pm 10,28 \mathbf{a b}$ & $11,35 \pm 2,73 \mathbf{a}$ \\
\hline FEE & $37,13 \pm 5,91 \mathbf{a b}$ & $9,72 \pm 2,04 \mathbf{a}$ \\
\hline FE1R & $57,05 \pm 7,60 \mathbf{a}$ & $12,40 \pm 4,73 \mathbf{a}$ \\
\hline \multirow[t]{2}{*}{ FE2R } & $54,63 \pm 10,99 \mathbf{a}$ & $13,06 \pm 3,17 \mathbf{a}$ \\
\hline & Taninos condensados $\left(\mathrm{g} \mathrm{kg}^{-1}\right)$ & \\
\hline FAE & $3,85 \pm 1,19 \mathbf{a}$ & \\
\hline FA1R & $3,78 \pm 1,28 \mathbf{a}$ & \\
\hline FA2R & $3,93 \pm 2,49 \mathbf{a}$ & \\
\hline FEE & $0,30 \pm 0,15 \mathbf{b}$ & \\
\hline FE1R & $0,54 \pm 0,36 \mathbf{b}$ & \\
\hline FE2R & $1,83 \pm 0,29 \mathbf{a b}$ & \\
\hline
\end{tabular}


Anexo E - Composição de compostos orgânicos das raízes de E. grandis e A. mangium no final do experimento de decomposição $(\mathrm{t}=367$ dias $)$ nos tratamentos raízes $\mathrm{RAE}$, RA1R, RA2R, REE, RE1R e RE2R. Os resultados representam a média $(n=3) \pm$ desvio padrão ${ }^{(1)}$

\begin{tabular}{|c|c|c|}
\hline \multicolumn{3}{|c|}{ Tratamentos } \\
\hline & Lignina $\left(\mathrm{g} \mathrm{kg}^{-1}\right)$ & Celulose $\left(\mathrm{g} \mathrm{kg}^{-1}\right)$ \\
\hline RAE & $242,02 \pm 45,74 \mathbf{a}$ & $131,95 \pm 36,56 \mathbf{a}$ \\
\hline RA1R & $232,42 \pm 67,15 \mathbf{a}$ & $118,99 \pm 26,88 \mathbf{a}$ \\
\hline RA2R & $233,08 \pm 65,78 \mathbf{a}$ & $142,56 \pm 37,58 \mathbf{a}$ \\
\hline REE & $152,13 \pm 69,37 \mathbf{a}$ & $156,20 \pm 58,42 \mathbf{a}$ \\
\hline RE1R & $238,44 \pm 1,18 \mathbf{a}$ & $172,51 \pm 13,67 \mathbf{a}$ \\
\hline \multirow[t]{2}{*}{ RE2R } & $207,15 \pm 46,58 \mathbf{a}$ & $154,63 \pm 27,67 \mathbf{a}$ \\
\hline & Hemicelulose $\left(\mathrm{g} \mathrm{kg}^{-1}\right)$ & Outros fenóis $\left(\mathrm{g} \mathrm{kg}^{-1}\right)$ \\
\hline RAE & $66,93 \pm 21,48 \mathbf{a}$ & $0,52 \pm 0,20 \mathbf{a}$ \\
\hline RA1R & $82,58 \pm 16,72 \mathbf{a}$ & $0,53 \pm 0,16 \mathbf{a}$ \\
\hline RA2R & $81,89 \pm 12,21 \mathbf{a}$ & $0,60 \pm 0,16 \mathbf{a}$ \\
\hline REE & $65,85 \pm 18,93 \mathbf{a}$ & $0,77 \pm 0,12 \mathbf{a}$ \\
\hline RE1R & $69,25 \pm 7,22 \mathbf{a}$ & $0,71 \pm 0,06 \mathbf{a}$ \\
\hline \multirow[t]{2}{*}{ RE2R } & $65,84 \pm 2,36 \mathbf{a}$ & $0,68 \pm 0,12 \mathbf{a}$ \\
\hline & Carboidratos solúveis $\left(\mathrm{g} \mathrm{kg}^{-1}\right)$ & Taninos totais $\left(\mathrm{g} \mathrm{kg}^{-1}\right)$ \\
\hline RAE & $21,43 \pm 3,39 \mathbf{b}$ & $1,34 \pm 0,70 \mathbf{a}$ \\
\hline RA1R & $26,22 \pm 2,26 \mathbf{a b}$ & $1,02 \pm 0,51 \mathbf{a}$ \\
\hline RA2R & $23,51 \pm 2,40 \mathbf{a b}$ & $0,89 \pm 0,80 \mathbf{a}$ \\
\hline REE & $27,99 \pm 5,53 \mathbf{a b}$ & $1,41 \pm 0,53 \mathbf{a}$ \\
\hline RE1R & $31,59 \pm 5,36 \mathbf{a}$ & $2,07 \pm 1,06 \mathbf{a}$ \\
\hline \multirow[t]{2}{*}{ RE2R } & $25,12 \pm 7,17 \mathbf{a b}$ & $1,21 \pm 0,22 \mathbf{a}$ \\
\hline & Taninos condensados $\left(\mathrm{g} \mathrm{kg}^{-1}\right)$ & \\
\hline RAE & $0,28 \pm 0,12 \mathbf{a}$ & \\
\hline RA1R & $0,26 \pm 0,15 \mathbf{a}$ & \\
\hline RA2R & $0,68 \pm 0,39 \mathbf{a}$ & \\
\hline REE & $0,11 \pm 0,07 \mathbf{a}$ & \\
\hline RE1R & $0,63 \pm 0,51 \mathbf{a}$ & \\
\hline RE2R & 0 & \\
\hline
\end{tabular}

Anexo F - Teores de carbono, nitrogênio, fósforo e potássio iniciais do material vegetal utilizado no experimento de decomposição ${ }^{(1)}$. Os valores representam a nédia $(n=9) \pm$ desvio padrão ${ }^{(2)}$

\begin{tabular}{|c|c|c|c|c|c|}
\hline Tipo de material & $\mathbf{C}$ & $\mathbf{N}$ & $\mathbf{S}$ & $\mathbf{P}$ & $\mathbf{K}$ \\
\hline Folha de acácia & $536,26 \pm 11,04 \mathbf{b}$ & $15,4 \pm 1,45 \mathbf{a}$ & $\frac{\mathbf{g}}{1,49 \pm 0,12 \mathbf{a}}$ & $0,30 \pm 0,07 \mathbf{a}$ & $7.84 \pm 0.07 \mathbf{a}$ \\
\hline Folha de eucalipto & $575,54 \pm 19,53 \mathbf{a}$ & $7,99 \pm 1,14 \mathbf{b}$ & $1,12 \pm 0,26 \mathbf{b}$ & $0,22 \pm 0,04 \mathbf{a}$ & $2,37 \pm 0,98 \mathbf{b}$ \\
\hline Raiz de acácia & $464,48 \pm 22,27 \mathbf{a}$ & $21,38 \pm 2,00 \mathbf{a}$ & $2,52 \pm 0,46 \mathbf{a}$ & $1,14 \pm 0,23 \mathbf{a}$ & $3,57 \pm 0,37 \mathbf{a}$ \\
\hline Raiz de eucalipto & $449,74 \pm 43,66 \mathbf{a}$ & $7,3 \pm 0,68 \mathbf{b}$ & $0,8 \pm 0,05 \mathbf{b}$ & $0,34 \pm 0,05 \mathbf{b}$ & $2,09 \pm 0,27 \mathbf{b}$ \\
\hline
\end{tabular}


Anexo G - Quantidade de carbono (g), nitrogênio, enxofre, fósforo e potássio ( $\mathrm{mg}$ ) iniciais do material vegetal utilizado no experimento de decomposição ${ }^{(1)}$. Média $(n=9) \pm$ desvio padrão ${ }^{(2)}$

\begin{tabular}{|c|c|c|c|c|c|}
\hline \multirow[t]{2}{*}{ Tipo de material } & $\mathbf{C}$ & $\mathbf{N}$ & $\mathbf{S}$ & $\mathbf{P}$ & $\mathbf{K}$ \\
\hline & "g" & \multicolumn{4}{|c|}{ mg } \\
\hline Folha de acácia & $6,80 \pm 0,24 \mathbf{b}$ & $195,79 \pm 19,41 \mathbf{a}$ & $18,96 \pm 1,74 \mathbf{a}$ & $4,08 \pm 1,22 \mathbf{a}$ & $98,64 \pm 10,26 \mathbf{a}$ \\
\hline Folha de eucalipto & $7,45 \pm 0,23 \mathbf{a}$ & $103,88 \pm 14,49 \mathbf{b}$ & $15,45 \pm 3,21 \mathbf{a}$ & $2,88 \pm 0,55 \mathbf{a}$ & $30,74 \pm 2,37 \mathbf{b}$ \\
\hline Raiz de acácia & $5,47 \pm 0,28 \mathbf{a}$ & $252 \pm 24,27 \mathbf{a}$ & $32,93 \pm 9,66 \mathbf{a}$ & $13,95 \pm 2,82 \mathbf{a}$ & $42,08 \pm 4,97 \mathbf{a}$ \\
\hline Raiz de eucalipto & $5,35 \pm 0,48 \mathbf{a}$ & $86,81 \pm 8,57 \mathbf{b}$ & $9,54 \pm 0,82 \mathbf{b}$ & $4,10 \pm 0,66 \mathbf{b}$ & $24,87 \pm 3,22 \mathbf{b}$ \\
\hline
\end{tabular}

(1) Folhas e raízes foram comparadas separadamente.

${ }^{(2)}$ Valores seguidos da mesma letra na coluna não diferem estatisticamente pelo teste Tukey $5 \%$.

Anexo H - Teores de carbono, nitrogênio, enxofre fósforo e potássio das folhas de serapilheira de $E$. grandis e A. mangium nos tratamentos FAE, FA1R, FA2R, FEE, FE1R e (FE2R durante o experimento de decomposição ${ }^{(1)}$. Os valores representam a média $(\mathrm{n}=9) \pm$ desvio padrão ${ }^{(2)}$

\begin{tabular}{|c|c|c|c|c|c|}
\hline Tratamentos & $\mathbf{C}$ & $\mathbf{N}$ & $\mathbf{S}$ & $\mathbf{P}$ & $\mathbf{K}$ \\
\hline & \multicolumn{5}{|c|}{$" \mathrm{~g} \mathrm{~kg}^{-1 . .}$} \\
\hline & & & $\mathrm{t}=92$ dias & & \\
\hline FAE & $505,90 \pm 46,08 \mathbf{b}$ & $17,80 \pm 3,78 \mathbf{a}$ & $1,29 \pm 0,25 \mathbf{a}$ & $0,33 \pm 0,11 \mathbf{a}$ & $1,23 \pm 0,32 \mathbf{b}$ \\
\hline FA1R & $532,11 \pm 33,04 \mathbf{a b}$ & $18,00 \pm 2,07 \mathbf{a}$ & $1,40 \pm 0,21 \mathbf{a}$ & $0,30 \pm 0,10 \mathbf{a}$ & $2,43 \pm 0,37 \mathbf{a}$ \\
\hline FA2R & $530,42 \pm 27,41 \mathbf{a b}$ & $16,19 \pm 1,85 \mathbf{a}$ & $1,20 \pm 0,15 \mathbf{a}$ & $0,23 \pm 0,05 \mathbf{a}$ & $0,9 \pm 0,26 \mathbf{b}$ \\
\hline FEE & $554,04 \pm 29,60 \mathbf{a b}$ & $9,67 \pm 1,39 \mathbf{b}$ & $1,28 \pm 0,18 \mathbf{a}$ & $0,30 \pm 0,10 \mathbf{a}$ & $0,7 \pm 0,1 \mathbf{b}$ \\
\hline FE1R & $574,99 \pm 36,11 \mathbf{a}$ & $9,57 \pm 1,14 \mathbf{b}$ & $1,29 \pm 0,37 \mathbf{a}$ & $0,30 \pm 0,10 \mathbf{a}$ & $1,13 \pm 0,32 \mathbf{b}$ \\
\hline FE2R & $546,15 \pm 52,71 \mathbf{a b}$ & $9,24 \pm 0,67 \mathbf{b}$ & $\begin{array}{l}1,24 \pm 0,23 \mathbf{a} \\
\mathbf{t}=\mathbf{1 8 1} \mathbf{d i a s}\end{array}$ & $0,30 \pm 0,10 \mathbf{a}$ & $0,67 \pm 0,11 \mathbf{b}$ \\
\hline FAE & $456,64 \pm 56,99 a$ & $17,88 \pm 2,55 \mathbf{a}$ & $0,99 \pm 0,10 \mathbf{a}$ & $0,17 \pm 0,05 \mathbf{b}$ & $0,63 \pm 0,05 \mathbf{a b}$ \\
\hline FA1R & $464,09 \pm 52,69 \mathbf{a}$ & $17,56 \pm 2,05 \mathbf{a}$ & $1,14 \pm 0,17 \mathbf{a}$ & $0,17 \pm 0,05 \mathbf{b}$ & $1,16 \pm 0,41 \mathbf{a}$ \\
\hline FA2R & $500,57 \pm 21,74 \mathbf{a}$ & $18,56 \pm 2,27 \mathbf{a}$ & $1,03 \pm 0,13 \mathbf{a}$ & $0,20 \pm 0 \mathbf{b}$ & $0,63 \pm 0,25 \mathbf{a b}$ \\
\hline FEE & $464,71 \pm 58,98$ a & $12,18 \pm 1,69 \mathbf{b}$ & $0,91 \pm 0,19 \mathbf{a}$ & $0,20 \pm 0 \mathbf{b}$ & $0,26 \pm 0,05 \mathbf{b}$ \\
\hline FE1R & $435,70 \pm 101,41 \mathbf{a}$ & $10,95 \pm 1,76 \mathbf{b}$ & $0,96 \pm 0,21 \mathbf{a}$ & $0,27 \pm 0,05 \mathbf{a}$ & $0,43 \pm 0,11 \mathbf{b}$ \\
\hline FE2R & $479,47 \pm 27,36 \mathbf{a}$ & $12,46 \pm 1,28 \mathbf{b}$ & $\begin{array}{l}0,91 \pm 0,19 \mathbf{a} \\
\mathbf{t}=\mathbf{2 7 5} \text { dias }\end{array}$ & $0,27 \pm 0,05 \mathbf{a}$ & $0,33 \pm 0,06 \mathbf{b}$ \\
\hline FAE & $452,22 \pm 41,80 \mathrm{ab}$ & $23,43 \pm 3,64 \mathbf{a}$ & $1,17 \pm 0,11 \mathbf{a b}$ & $0,37 \pm 0,03 \mathbf{a}$ & $0,63 \pm 0,06 \mathbf{c}$ \\
\hline FA1R & $489,80 \pm 31,13 \mathbf{a}$ & $20,40 \pm 1,71 \mathbf{a b}$ & $1,32 \pm 0,16 \mathbf{a}$ & $0,32 \pm 0,0 \mathbf{a}$ & $0,93 \pm 0,15 \mathbf{b c}$ \\
\hline FA2R & $436,40 \pm 60,55 \mathbf{a b}$ & $18,28 \pm 2,78 \mathbf{b}$ & $0,97 \pm 0,17 \mathbf{b c}$ & $0,29 \pm 0,08 \mathbf{a}$ & $0,83 \pm 0,06 \mathbf{c}$ \\
\hline FEE & $399,19 \pm 55,80 \mathbf{b}$ & $10,67 \pm 0,90 \mathbf{c}$ & $0,88 \pm 0,24 \mathbf{c}$ & $0,29 \pm 0 \mathbf{a}$ & $1,20 \pm 0,17 \mathbf{a b}$ \\
\hline FE1R & $449,03 \pm 61,01 \mathbf{a b}$ & $12,00 \pm 1,59 \mathbf{c}$ & $1,25 \pm 0,26 \mathbf{a}$ & $0,34 \pm 0 \mathbf{a}$ & $1,27 \pm 0,06 \mathbf{a}$ \\
\hline FE2R & $436,40 \pm 47,55 \mathbf{a b}$ & $11,85 \pm 1,34 \mathbf{c}$ & $\begin{array}{l}1,16 \pm 0,18 \text { ab } \\
\mathbf{t}=\mathbf{3 6 7} \text { dias }\end{array}$ & $0,34 \pm 0 \mathrm{a}$ & $1,30 \pm 0,10 \mathbf{a}$ \\
\hline FAE & $374,55 \pm 39,08 \mathbf{b}$ & $17,02 \pm 1,54 \mathbf{b}$ & $1,20 \pm 0,12 \mathbf{a b}$ & $0,59 \pm 0,08 \mathbf{a}$ & $0,30 \pm 0,00 \mathbf{b}$ \\
\hline FA1R & $448,88 \pm 48,79 \mathbf{a}$ & $19,97 \pm 2,13 \mathbf{a}$ & $1,32 \pm 0,24 \mathbf{a}$ & $0,62 \pm 0,03 \mathbf{a}$ & $0,60 \pm 0,10 \mathbf{a}$ \\
\hline FA2R & $457,93 \pm 25,35 \mathbf{a}$ & $19,76 \pm 2,02 \mathbf{a}$ & $1,34 \pm 0,26 \mathbf{a}$ & $0,51 \pm 0,05 \mathbf{a}$ & $0,43 \pm 0,06 \mathbf{a b}$ \\
\hline FEE & $425,89 \pm 47,86 \mathbf{a b}$ & $13,81 \pm 1,06 \mathbf{c}$ & $0,94 \pm 0,13 \mathbf{c}$ & $0,66 \pm 0,07 \mathbf{a}$ & $0,33 \pm 0,06 \mathbf{b}$ \\
\hline FE1R & $432,52 \pm 59,69 \mathbf{a b}$ & $12,58 \pm 2,12 \mathbf{c}$ & $0,91 \pm 0,15 \mathbf{c}$ & $0,60 \pm 0,07 \mathbf{a}$ & $0,37 \pm 0,06 \mathbf{b}$ \\
\hline FE2R & $451,99 \pm 51,88 \mathbf{a}$ & $12,96 \pm 1,45 \mathbf{c}$ & $0,96 \pm 0,15 \mathbf{b c}$ & $0,60 \pm 0,03 \mathbf{a}$ & $0,33 \pm 0,06 \mathbf{b}$ \\
\hline
\end{tabular}

As datas foram comparadas separadamente.

(2) Médias seguidas da mesma letra nas colunas não diferem estatisticamente pelo teste de Tukey a 5\% de probabilidade. 
Anexo I - Teores de carbono, nitrogênio, enxofre, fósforo e potássio das raízes de $E$. grandis e A. mangium nos tratamentos RAE, RA1R, RA2R, REE, RE1R e RE2R durante o experimento de decomposição ${ }^{(1)}$. Os valores representam a média $(\mathrm{n}=9) \pm$ desvio padrão ${ }^{(2)}$

\begin{tabular}{|c|c|c|c|c|c|}
\hline \multirow[t]{2}{*}{ Tratamentos } & $\mathbf{C}$ & $\mathbf{N}$ & $\mathbf{S}$ & $\mathbf{P}$ & $\mathbf{K}$ \\
\hline & \multicolumn{5}{|c|}{$" \mathrm{~g} \mathrm{~kg}^{-1 \ldots . . .}$} \\
\hline & & & $t=92$ dias & & \\
\hline RAE & $447,43 \pm 71,56 \mathbf{a}$ & $19,62 \pm 2,74 \mathbf{a}$ & $3,05 \pm 0,73 \mathbf{a}$ & $0,53 \pm 0,06 \mathbf{a}$ & $0,33 \pm 0,06 \mathbf{a}$ \\
\hline RA1R & $460,05 \pm 36,89 \mathbf{a}$ & $21,40 \pm 2,34 \mathbf{a}$ & $3,11 \pm 0,73 \mathbf{a}$ & $0,40 \pm 0,10 \mathbf{a}$ & $0,37 \pm 0,06 \mathbf{a}$ \\
\hline RA2R & $469,62 \pm 38,05 \mathbf{a}$ & $20,04 \pm 2,21 \mathbf{a}$ & $3,04 \pm 0,90 \mathbf{a}$ & $0,40 \pm 0,10 \mathbf{a}$ & $0,37 \pm 0,06 \mathbf{a}$ \\
\hline REE & $436,98 \pm 34,80 \mathbf{a}$ & $8,89 \pm 1,02 \mathbf{b}$ & $0,85 \pm 0,16 \mathbf{b}$ & $0,40 \pm 0 \mathbf{a}$ & $0,50 \pm 0,10 \mathbf{a}$ \\
\hline RE1R & $428,98 \pm 41,62 \mathbf{a}$ & $9,02 \pm 1,29 \mathbf{b}$ & $0,96 \pm 0,16 \mathbf{b}$ & $0,43 \pm 0,53 \mathbf{a}$ & $0,36 \pm 0,06 \mathbf{a}$ \\
\hline RE2R & $425,86 \pm 49,40 \mathbf{a}$ & $9.08 \pm 1,41 \mathbf{b}$ & $\begin{array}{l}0,96 \pm 0,33 \mathbf{b} \\
\mathbf{t}=\mathbf{1 8 1} \text { dias }\end{array}$ & $0,43 \pm 0,06 \mathbf{a}$ & $0,37 \pm 0,11 \mathbf{a}$ \\
\hline RAE & $430,32 \pm 82,94 \mathbf{a}$ & $20,18 \pm 4,36 \mathbf{a}$ & $2,67 \pm 0,59 \mathbf{a}$ & $0,43 \pm 0,05 \mathbf{a}$ & $0,33 \pm 0,06 \mathbf{a b}$ \\
\hline RA1R & $492,75 \pm 46,84 \mathbf{a}$ & $24,32 \pm 2,96 \mathbf{a}$ & $2,82 \pm 0,15 \mathbf{a}$ & $0,43 \pm 0,05 \mathbf{a}$ & $0,23 \pm 0,06 \mathbf{b c}$ \\
\hline RA2R & $464,82 \pm 61,33 \mathbf{a}$ & $21,38 \pm 3,94 \mathbf{a}$ & $2,48 \pm 0,91 \mathbf{a}$ & $0,40 \pm 0 \mathbf{a}$ & $0,36 \pm 0,06 \mathbf{a}$ \\
\hline REE & $447,58 \pm 50,70 \mathbf{a}$ & $9,27 \pm 0,91 \mathbf{b}$ & $0,78 \pm 0,18 \mathbf{b}$ & $0,40 \pm 0 \mathbf{a}$ & $0,30 \pm 0,06 \mathbf{a b c}$ \\
\hline RE1R & $460,33 \pm 44,78 \mathbf{a}$ & $10,72 \pm 1,76 \mathbf{b}$ & $0,79 \pm 0,15 \mathbf{b}$ & $0,43 \pm 0,05 \mathbf{a}$ & $0,20 \pm 0 \mathbf{c}$ \\
\hline RE2R & $445,98 \pm 35,30 \mathbf{a}$ & $10,03 \pm 1,21 \mathbf{b}$ & $\begin{array}{l}0,82 \pm 0,22 \mathbf{b} \\
\mathbf{t}=\mathbf{2 7 5} \text { dias }\end{array}$ & $0,46 \pm 0,05 \mathbf{a}$ & $0,26 \pm 0,06 \mathbf{a b c}$ \\
\hline RAE & $419,27 \pm 2,27 \mathbf{a}$ & $20,78 \pm 3,12 \mathbf{a}$ & $1,86 \pm 0,62 \mathbf{a}$ & $0,52 \pm 0,02 \mathbf{a}$ & $0,80 \pm 0 \mathbf{b}$ \\
\hline RA1R & $430,98 \pm 50,98 \mathbf{a}$ & $21,73 \pm 4,28 \mathbf{a}$ & $2,44 \pm 0,82 \mathbf{a}$ & $0,50 \pm 0,11 \mathbf{a}$ & $0,87 \pm 0,11 \mathbf{b}$ \\
\hline RA2R & $432,79 \pm 50,98 \mathbf{a}$ & $22,80 \pm 2,42 \mathbf{a}$ & $2,37 \pm 0,55 \mathbf{a}$ & $0,52 \pm 0,07 \mathbf{a}$ & $0,97 \pm 0,06 \mathbf{b}$ \\
\hline REE & $392,42 \pm 36,37 \mathbf{a}$ & $12,68 \pm 2,42 \mathbf{b}$ & $1,21 \pm 0,48 \mathbf{a}$ & $0,46 \pm 0,02 \mathbf{a}$ & $1,33 \pm 0,06 \mathbf{a}$ \\
\hline RE1R & $422,63 \pm 44,53 \mathbf{a}$ & $13,70 \pm 0,89 \mathbf{b}$ & $1,16 \pm 0,14 \mathbf{a}$ & $0,46 \pm 0,03 \mathbf{a}$ & $1,33 \pm 0,11 \mathbf{a}$ \\
\hline RE2R & $408,77 \pm 35,12 \mathbf{a}$ & $14,08 \pm 1,96 \mathbf{b}$ & $\begin{array}{l}1,20 \pm 0,18 \mathbf{a} \\
\mathbf{t}=\mathbf{3 6 7} \text { dias }\end{array}$ & $0,44 \pm 0,07 \mathbf{a}$ & $1,37 \pm 0,11 \mathbf{a}$ \\
\hline RAE & $366,21 \pm 66,78 \mathbf{a}$ & $19,33 \pm 3,08 \mathbf{a}$ & $2,40 \pm 0,76 \mathbf{a}$ & $0,79 \pm 0,02 \mathbf{a b}$ & $0,20 \pm 0 \mathbf{a}$ \\
\hline RA1R & $371,19 \pm 65,03 \mathbf{a}$ & $20,88 \pm 4,02 \mathbf{a}$ & $2,47 \pm 1,06 \mathbf{a}$ & $0,83 \pm 0,04 \mathbf{a}$ & $0,27 \pm 0,06 \mathbf{a}$ \\
\hline RA2R & $388,09 \pm 64,36 \mathbf{a}$ & $21,73 \pm 3,80 \mathbf{a}$ & $2,79 \pm 1,05 \mathbf{a}$ & $0,75 \pm 0,09 \mathbf{a b c}$ & $0,30 \pm 0,10 \mathbf{a}$ \\
\hline REE & $347,82 \pm 82,66 \mathbf{a}$ & $11,57 \pm 1,69 \mathbf{b}$ & $0,72 \pm 0,15 \mathbf{b}$ & $0,63 \pm 0,11 \mathbf{c}$ & $0,20 \pm 0 \mathbf{a}$ \\
\hline RE1R & $409,57 \pm 45,91 \mathbf{a}$ & $14,10 \pm 0,80 \mathbf{b}$ & $1,02 \pm 0,11 \mathbf{b}$ & $0,71 \pm 0,04 \mathbf{a b c}$ & $0,23 \pm 0,06 \mathbf{a}$ \\
\hline RE2R & $362,72 \pm 77,21 \mathbf{a}$ & $13,05 \pm 0,91 \mathbf{b}$ & $0,91 \pm 0,27 \mathbf{b}$ & $0,66 \pm 0,08 \mathbf{b c}$ & $0,20 \pm 0 \mathbf{a}$ \\
\hline
\end{tabular}

(1) As datas foram comparadas separadamente.

(2) Médias seguidas da mesma letra nas colunas não diferem estatisticamente pelo teste de Tukey a 5\% de probabilidade. 
Anexo J - Quantidade de carbono (g), nitrogênio, enxofre, fósforo e potássio (mg) das folhas de serapilheira de E. grandis e A. mangium nos tratamentos FAE, FA1R, FA2R, FEE, FE1R e FE2R durante o experimento de decomposição ${ }^{(1)}$. Os valores representam a média $(n=9) \pm$ desvio padrão ${ }^{(2)}$

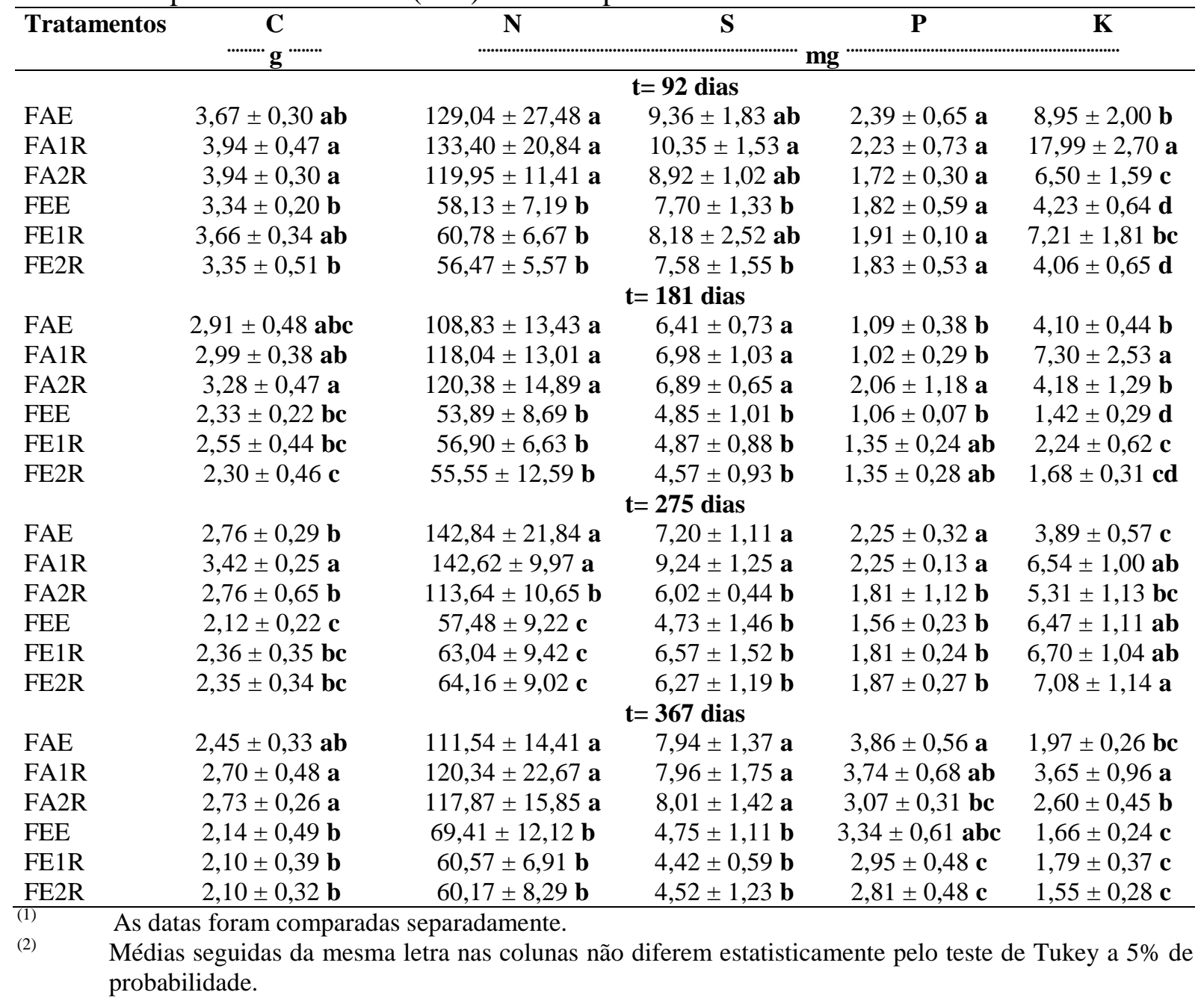


Anexo K - Quantidade de carbono (g), nitrogênio, enxofre, fósforo e potássio ( $\mathrm{mg}$ ) das raízes de E. grandis e A. mangium durante o experimento ${ }^{(1)}$ nos tratamentos RAE, RA1R, RA2R, REE, RE1R e RE2R. Os valores representam a média $(n=9) \pm$ desvio padrão ${ }^{(2)}$

\begin{tabular}{|c|c|c|c|c|c|}
\hline \multirow[t]{3}{*}{ Tratamentos } & $\mathbf{C}$ & $\mathbf{N}$ & $\mathbf{S}$ & \multirow{3}{*}{ ng * } & $\mathbf{K}$ \\
\hline & \multirow{2}{*}{\multicolumn{4}{|c|}{$t=92$ dias }} & $\cdots \cdots \cdots \cdots \cdots \cdots$ \\
\hline & & & & & \\
\hline RAE & $1,58 \pm 0,22 \mathbf{a b}$ & $69,52 \pm 8,10 \mathbf{a}$ & $10,86 \pm 3,32 \mathbf{a}$ & $1,91 \pm 0,30 \mathbf{a}$ & $1,19 \pm 0,24 \mathbf{b}$ \\
\hline RA1R & $1,59 \pm 0,35 \mathbf{a}$ & $73,40 \pm 14,65 \mathbf{a}$ & $11,55 \pm 2,32 \mathbf{a}$ & $1,41 \pm 0,50 \mathbf{b}$ & $1,28 \pm 0,36 \mathbf{b}$ \\
\hline RA2R & $1,55 \pm 0,34 \mathbf{a}$ & $65,16 \pm 10,00 \mathbf{a}$ & $10,74 \pm 2,56 \mathbf{a}$ & $1,34 \pm 0,49 \mathbf{b}$ & $1,21 \pm 0,31 \mathbf{b}$ \\
\hline REE & $1,59 \pm 0,21 \mathbf{b}$ & $32,20 \pm 3,97 \mathbf{b}$ & $3,11 \pm 0,64 \mathbf{b}$ & $1,45 \pm 0,14 \mathbf{a b}$ & $1,81 \pm 0,31 \mathbf{a}$ \\
\hline RE1R & $1,61 \pm 0,15 \mathbf{b}$ & $33,89 \pm 4,65 \mathbf{b}$ & $3,62 \pm 0,65 \mathbf{b}$ & $1,63 \pm 0,22 \mathbf{a b}$ & $1,39 \pm 0,26 \mathbf{a b}$ \\
\hline RE2R & $1,61 \pm 0,27 \mathbf{b}$ & $35,10 \pm 7,45 \mathbf{b}$ & $\begin{aligned} & 3,73 \pm 1,28 \mathbf{b} \\
& \mathbf{t}=\mathbf{1 8 1} \text { dias }\end{aligned}$ & $1,63 \pm 0,27 \mathbf{a b}$ & $1,38 \pm 0,43 \mathbf{a b}$ \\
\hline RAE & $1,07 \pm 0,49 \mathbf{a}$ & $49,51 \pm 21,59 \mathbf{a}$ & $5,70 \pm 4,02 \mathbf{a}$ & $1,01 \pm 0,36 \mathbf{a}$ & $0,78 \pm 0,27 \mathbf{a b}$ \\
\hline RA1R & $1,35 \pm 0,37 \mathbf{a}$ & $66,88 \pm 19,07 \mathbf{a}$ & $7,92 \pm 2,08 \mathbf{a}$ & $1,24 \pm 0,20 \mathbf{a}$ & $0,68 \pm 0,22 \mathbf{b}$ \\
\hline RA2R & $1,42 \pm 0,21 \mathbf{a}$ & $39,47 \pm 4,12 \mathbf{a b}$ & $7,85 \pm 2,88 \mathbf{a}$ & $1,28 \pm 0,17 \mathbf{a}$ & $1,16 \pm 0,15 \mathbf{a}$ \\
\hline REE & $1,14 \pm 0,18 \mathbf{a}$ & $30,46 \pm 3,67 \mathbf{b}$ & $1,91 \pm 0,23 \mathbf{b}$ & $1,04 \pm 0,13 \mathbf{a}$ & $0,78 \pm 0,09 \mathbf{a b}$ \\
\hline RE1R & $1,31 \pm 0,22 \mathbf{a}$ & $35,41 \pm 5,78 \mathbf{a b}$ & $1,74 \pm 1,14 \mathbf{b}$ & $1,22 \pm 0,18 \mathbf{a}$ & $0,57 \pm 0,07 \mathbf{b}$ \\
\hline RE2R & $1,23 \pm 0,20 \mathbf{a}$ & $34,33 \pm 5,60 \mathbf{a b}$ & $\begin{aligned} & 2,22 \pm 0,47 \mathbf{b} \\
\mathbf{t}= & \mathbf{2 7 5} \operatorname{dias}\end{aligned}$ & $1,28 \pm 0,10 \mathbf{a}$ & $0,72 \pm 0,09 \mathbf{a b}$ \\
\hline RAE & $1,12 \pm 0,15 \mathbf{a b}$ & $55,54 \pm 7,73 \mathbf{a b}$ & $4,96 \pm 1,56 \mathbf{a b}$ & $1,43 \pm 0,25 \mathbf{a}$ & $2,17 \pm 0,39 \mathbf{a}$ \\
\hline RA1R & $1,13 \pm 0,25 \mathbf{a}$ & $57,34 \pm 18,02 \mathbf{a b}$ & $6,56 \pm 3,16 \mathbf{a b}$ & $1,33 \pm 0,35 \mathbf{a}$ & $2,27 \pm 0,18 \mathbf{a}$ \\
\hline RA2R & $1,32 \pm 0,22 \mathbf{a b}$ & $69,46 \pm 11,43 \mathbf{a}$ & $7,14 \pm 1,45 \mathbf{a}$ & $1,62 \pm 0,46 \mathbf{a}$ & $2,98 \pm 0,46 \mathbf{a}$ \\
\hline REE & $0,82 \pm 0,25 \mathrm{~b}$ & $26,64 \pm 10,01 \mathbf{b}$ & $2,59 \pm 1,57 \mathbf{b}$ & $0,96 \pm 0,21 \mathbf{a}$ & $2,79 \pm 0,74 \mathbf{a}$ \\
\hline RE1R & $1,00 \pm 0,27 \mathbf{a b}$ & $32,43 \pm 8,19 \mathbf{b}$ & $2,77 \pm 0,84 \mathbf{b}$ & $1,09 \pm 0,29 \mathbf{a}$ & $3,15 \pm 0,81 \mathbf{a}$ \\
\hline RE2R & $0,93 \pm 0,28 \mathbf{a b}$ & $31,44 \pm 8,50 \mathbf{b}$ & $\begin{aligned} & 2,72 \pm 0,90 \mathbf{b} \\
\mathbf{t}= & \mathbf{3 6 7} \text { dias }\end{aligned}$ & $0,99 \pm 0,30 \mathbf{a}$ & $3,10 \pm 0,92 \mathbf{a}$ \\
\hline RAE & $1,07 \pm 0,49 \mathbf{a}$ & $63,12 \pm 12,60 \mathbf{a}$ & $7,72 \pm 1,90 \mathbf{a}$ & $2,61 \pm 0,44 \mathbf{a}$ & $0,66 \pm 0,11 \mathbf{a}$ \\
\hline RA1R & $1,08 \pm 0,18 \mathbf{a b}$ & $60,44 \pm 9,82 \mathbf{a}$ & $6,96 \pm 2,28 \mathbf{a}$ & $2,46 \pm 0,35 \mathbf{a b}$ & $0,78 \pm 0,17 \mathbf{a}$ \\
\hline RA2R & $1,07 \pm 0,31 \mathbf{a}$ & $60,42 \pm 19,62 \mathbf{a}$ & $7,78 \pm 3,50 \mathbf{a}$ & $2,07 \pm 0,39 \mathbf{a b}$ & $0,82 \pm 0,25 \mathbf{a}$ \\
\hline REE & $0,85 \pm 0,21 \mathbf{b}$ & $28,60 \pm 6,81 \mathbf{b}$ & $1,78 \pm 0,41 \mathbf{b}$ & $1,58 \pm 0,31 \mathbf{b}$ & $0,51 \pm 0,17 \mathbf{a}$ \\
\hline RE1R & $0,87 \pm 0,31 \mathbf{b}$ & $29,92 \pm 9,74 \mathbf{b}$ & $2,18 \pm 0,70 \mathbf{b}$ & $1,52 \pm 0,53 \mathbf{b}$ & $0,49 \pm 0,21 \mathbf{a}$ \\
\hline RE2R & $0,83 \pm 0,19 \mathbf{b}$ & $30,51 \pm 6,21 \mathbf{b}$ & $2,13 \pm 0,84 \mathbf{b}$ & $1,56 \pm 0,37 \mathbf{b}$ & $0,47 \pm 0,10 \mathbf{a}$ \\
\hline
\end{tabular}


Anexo L - Relação C/N e N/P das folhas e raízes ${ }^{(1)}$ de E. grandis e A. mangium durante o final do experimento de decomposição ${ }^{(2)}$ nos (FAE), (FA1R), (FA2R), (FEE), (FE1R), e (FE2R). Os resultados representam a média $(n=3) \pm$ desvio padrão $^{(3)}$

\begin{tabular}{|c|c|c|c|c|c|}
\hline Tratamentos & $\mathbf{C} / \mathbf{N}$ & $\mathbf{N} / \mathbf{P}$ & Tratamentos & $\mathbf{C} / \mathbf{N}$ & $\mathbf{N} / \mathbf{P}$ \\
\hline folhas & \multicolumn{2}{|c|}{$\mathbf{t}=\mathbf{0}$ dia } & raízes & \multicolumn{2}{|c|}{$\mathbf{t}=\mathbf{0}$ dia } \\
\hline FA & $35,08 \pm 3,92 \mathbf{b}$ & $50,87 \pm 11,91 \mathbf{a}$ & $\mathbf{R A}$ & $21,86 \pm 2,04 \mathbf{b}$ & $20,32 \pm 6,56 \mathbf{a}$ \\
\hline \multirow[t]{2}{*}{$\mathbf{F E}$} & $72,03 \pm 10,35 \mathbf{a}$ & $36,47 \pm 4,33 \mathbf{b}$ & RE & $61,74 \pm 3,55 \mathbf{a}$ & $21,66 \pm 4,09 \mathbf{a}$ \\
\hline & \multicolumn{2}{|c|}{$\mathrm{t}=92$ dias } & & \multicolumn{2}{|c|}{$\mathrm{t}=92$ dias } \\
\hline FAE & $29,29 \pm 5,22 \mathbf{b}$ & $56,76 \pm 15,13 \mathbf{b}$ & RAE & $22,91 \pm 3,38 \mathbf{b}$ & $37,04 \pm 5,71 \mathbf{b}$ \\
\hline FA1R & $29,85 \pm 3,32 \mathbf{b}$ & $64,86 \pm 21,05 \mathbf{a b}$ & RA1R & $21,71 \pm 2,90 \mathbf{b}$ & $56,06 \pm 14,72 \mathbf{a}$ \\
\hline FA2R & $33,07 \pm 3,32 \mathbf{b}$ & $71,40 \pm 13,32 \mathbf{a}$ & RA2R & $23,73 \pm 3,61 \mathbf{b}$ & $53,02 \pm 15,79$ a \\
\hline FEE & $58,16 \pm 7,58 \mathbf{a}$ & $35,73 \pm 15,20 \mathbf{c}$ & REE & $49,60 \pm 6,26 \mathbf{a}$ & $22,24 \pm 2,54 \mathbf{c}$ \\
\hline FE1R & $60,70 \pm 6,64 \mathbf{a}$ & $31,89 \pm 3,81 \mathbf{c}$ & RE1R & $48,05 \pm 5,66 \mathbf{a}$ & $21,00 \pm 3,62 \mathbf{c}$ \\
\hline \multirow[t]{2}{*}{ FE2R } & $59,61 \pm 9,00 \mathbf{a}$ & $33,29 \pm 10,08 \mathbf{c}$ & RE2R & $47,29 \pm 4,31 \mathbf{a}$ & $21,56 \pm 3,25 \mathbf{c}$ \\
\hline & \multicolumn{2}{|c|}{$\mathrm{t}=181$ dias } & & \multicolumn{2}{|c|}{$t=181$ dias } \\
\hline FAE & $25,62 \pm 1,17 \mathbf{b}$ & $80,97 \pm 15,13 \mathbf{a}$ & RAE & $21,43 \pm 1,77 \mathbf{b}$ & $46,86 \pm 10,83 \mathbf{a}$ \\
\hline FA1R & $26,50 \pm 1,85 \mathbf{b}$ & $97,93 \pm 21,04 \mathbf{a}$ & RA1R & $20,32 \pm 0,77 \mathbf{b}$ & $56,30 \pm 9,61 \mathbf{a}$ \\
\hline FA2R & $27,31 \pm 3,49 \mathbf{b}$ & $93,48 \pm 13,32 \mathbf{a}$ & RA2R & $22,13 \pm 3,63 \mathbf{b}$ & $53,45 \pm 9,85 \mathbf{a}$ \\
\hline FEE & $38,69 \pm 7,67 \mathbf{a}$ & $50,81 \pm 9,23 \mathbf{b}$ & REE & $37,80 \pm 3,11 \mathbf{a}$ & $23,17 \pm 0,62 \mathbf{b}$ \\
\hline FE1R & $39,69 \pm 6,05 \mathbf{a}$ & $43,63 \pm 11,53 \mathbf{b}$ & RE1R & $36,98 \pm 5,37 \mathbf{a}$ & $24,78 \pm 2,91 \mathbf{b}$ \\
\hline \multirow[t]{2}{*}{ FE2R } & $38,71 \pm 3,01 \mathbf{a}$ & $41,91 \pm 8,82 \mathbf{b}$ & RE2R & $36,01 \pm 3,01 \mathbf{a}$ & $21,65 \pm 2,75 \mathbf{b}$ \\
\hline & \multicolumn{2}{|c|}{$t=275$ dias } & & \multicolumn{2}{|c|}{$t=275$ dias } \\
\hline FAE & $19,60 \pm 2,61 \mathbf{b}$ & $63,80 \pm 7,88 \mathbf{a}$ & RAE & $20,3 \pm 2,27 \mathbf{b}$ & $38,03 \pm 7,79 \mathbf{a b}$ \\
\hline FA1R & $24,19 \pm 2,69 \mathbf{b}$ & $63,40 \pm 5,33 \mathbf{a}$ & RA1R & $20,30 \pm 3,32 \mathbf{b}$ & $47,98 \pm 9,86 \mathbf{a}$ \\
\hline FA2R & $24,21 \pm 4,38 \mathbf{b}$ & $64,64 \pm 14,57 \mathbf{a}$ & RA2R & $19,07 \pm 1,28 \mathbf{b}$ & $44,51 \pm 8,60 \mathbf{a}$ \\
\hline FEE & $37,48 \pm 4,73 \mathbf{a}$ & $36,93 \pm 3,11 \mathbf{b}$ & REE & $31,57 \pm 4,76 \mathbf{a}$ & $27,71 \pm 5,94 \mathbf{c}$ \\
\hline FE1R & $37,51 \pm 3,37 \mathbf{a}$ & $35,00 \pm 4,65 \mathbf{b}$ & RE1R & $30,81 \pm 2,21 \mathbf{a}$ & $29,36 \pm 2,78 \mathbf{b c}$ \\
\hline \multirow[t]{2}{*}{ FE2R } & $36,94 \pm 3,03 \mathbf{a}$ & $34,57 \pm 3,92 \mathbf{b}$ & RE2R & $29,43 \pm 3,88 \mathbf{a}$ & $32,86 \pm 7,48 \mathbf{b c}$ \\
\hline & \multicolumn{2}{|c|}{$\mathrm{t}=367$ dias } & & \multicolumn{2}{|c|}{$t=367$ dias } \\
\hline FAE & $22,04 \pm 1,58 \mathbf{b}$ & $29,35 \pm 4,94 \mathbf{b}$ & RAE & $18,90 \pm 1.30 \mathbf{b}$ & $23,64 \pm 3,61 \mathbf{a b}$ \\
\hline FA1R & $22,55 \pm 2,13 \mathbf{b}$ & $33,31 \pm 3,70 \mathbf{b}$ & RA1R & $17,86 \pm 1,21 \mathbf{b}$ & $25,61 \pm 4,46 \mathbf{a}$ \\
\hline FA2R & $23,36 \pm 2,41 \mathbf{b}$ & $38,46 \pm 4,14 \mathbf{a}$ & RA2R & $17,95 \pm 1,61 \mathbf{b}$ & $28,90 \pm 5,05 \mathbf{a}$ \\
\hline FEE & $30,95 \pm 3,87 \mathbf{a}$ & $20,86 \pm 1,89 \mathbf{c}$ & REE & $29,88 \pm 4,26 \mathbf{a}$ & $19,10 \pm 2,83 \mathbf{b}$ \\
\hline FE1R & $34,70 \pm 4,33 \mathbf{a}$ & $20,82 \pm 2,32 \mathbf{c}$ & RE1R & $28,99 \pm 2,31 \mathbf{a}$ & $19,80 \pm 1,35 \mathbf{b}$ \\
\hline FE2R & $34,88 \pm 1,57 \mathbf{a}$ & $21,60 \pm 2,24 \mathbf{c}$ & RE2R & $27,55 \pm 4,30 \mathbf{a}$ & $19,96 \pm 3,24 \mathbf{b}$ \\
\hline
\end{tabular}

${ }^{(1)}$ Folhas e raízes foram comparadas separadamente.

(2) As datas foram comparadas separadamente.

(3) Médias seguidas da mesma letra nas colunas não diferem estatisticamente pelo teste de Tukey a $5 \%$ de probabilidade. 
Anexo M - Quantidade de nitrogênio total (g) e nitrogênio transferido (\%) nas folhas durante o experimento de transferência de $\mathrm{N}^{(1)}$ nos tratamentos drenos AFA*, AFE*, EFA* $^{*}$ e EFE. Os resultados representam a média $(n=4) \pm$ desvio padrão $^{(2)}$

\begin{tabular}{|c|c|c|c|}
\hline Tratamentos & $\begin{array}{l}\text { Ntotal } \\
\cdots \cdots . . . \\
\cdots\end{array}$ & & $\begin{array}{c}\mathbf{N t} \\
\ldots \ldots \ldots . . . . \\
\%\end{array}$ \\
\hline & & $\mathbf{t}=\mathbf{0} \operatorname{dias}$ & \\
\hline AFA* & $0,64 \pm 0,07 \mathbf{a}$ & & 0 \\
\hline $\mathrm{AFE}^{*}$ & $0,61 \pm 0,08 \mathbf{a}$ & & 0 \\
\hline EFA* & $0,38 \pm 0,06 \mathbf{b}$ & & 0 \\
\hline \multirow[t]{2}{*}{ EFE* } & $0,36 \pm 0,05 \mathbf{b}$ & & 0 \\
\hline & & $\mathbf{t}=90 \operatorname{dias}$ & \\
\hline AFA* & $0,79 \pm 0,13 \mathbf{a}$ & & $68,66 \pm 14,73 \mathbf{a}$ \\
\hline $\mathrm{AFE}^{*}$ & $0,67 \pm 0,15 \mathbf{a}$ & & $94,90 \pm 33 \mathbf{a}$ \\
\hline EFA* & $0,36 \pm 0,07 \mathbf{b}$ & & $22,04 \pm 8,37 \mathbf{b}$ \\
\hline \multirow[t]{2}{*}{ EFE* } & $0,41 \pm 0,05 \mathbf{b}$ & & $16,74 \pm 10,67 \mathbf{b}$ \\
\hline & & $t=182 \operatorname{dias}$ & \\
\hline $\mathrm{AFA}^{*}$ & $0,77 \pm 0,17 \mathbf{a}$ & & $68,28 \pm 13 \mathbf{a}$ \\
\hline $\mathrm{AFE}^{*}$ & $0,67 \pm 0,19 \mathbf{a}$ & & $100 \pm 20 \mathbf{a}$ \\
\hline EFA* & $0,32 \pm 0,08 \mathbf{b}$ & & $20,60 \pm 5,79 \mathbf{b}$ \\
\hline \multirow[t]{2}{*}{ EFE* } & $0,40 \pm 0,08 \mathbf{b}$ & & $30,25 \pm 13,74 \mathbf{b}$ \\
\hline & & $\mathrm{t}=274$ dias & \\
\hline $\mathrm{AFA}^{*}$ & $0,75 \pm 0,14 \mathbf{a}$ & & $64,42 \pm 15,40 \mathbf{b}$ \\
\hline AFE* & $0,86 \pm 0,28 \mathbf{a}$ & & $100 \pm 18 \mathbf{a}$ \\
\hline EFA* & $0,32 \pm 0,09 \mathbf{b}$ & & $20,87 \pm 7,05 \mathbf{c}$ \\
\hline \multirow[t]{2}{*}{ EFE* } & $0,41 \pm 0,08 \mathbf{b}$ & & $25,27 \pm 12,29 \mathbf{c}$ \\
\hline & & $t=364$ dias & \\
\hline AFA* & $0,55 \pm 0,15 \mathbf{a}$ & & $43,12 \pm 14,74 \mathbf{a}$ \\
\hline AFE* & $0,45 \pm 0,12 \mathbf{a b}$ & & $44,81 \pm 14,24 \mathbf{a}$ \\
\hline EFA* & $0,28 \pm 0,10 \mathbf{a b}$ & & $15,79 \pm 9,46 \mathbf{b}$ \\
\hline EFE* & $0,33 \pm 0,08 \mathbf{b}$ & & $8,21 \pm 3,67 \mathbf{b}$ \\
\hline
\end{tabular}

(1) As datas foram comparadas separadamente.

(2) Médias seguidas da mesma letra nas colunas não diferem estatisticamente pelo teste de Tukey a 5\% de probabilidade 